\begin{tabular}{|c|c|c|}
\hline $\begin{array}{c}\text { UnB } \\
\begin{array}{c}\text { Universidade } \\
\text { de Brasilia }\end{array}\end{array}$ & $\begin{array}{c}\text { UFPB } \\
\text { UNIVERIDADE FEDERAL } \\
\text { DA PARAIBA }\end{array}$ & $\begin{array}{c}\text { UFRN } \\
\text { UNIVERSIDADE FEDERAL do } \\
\text { RIO GRANDE DO NORTE }\end{array}$ \\
\hline
\end{tabular}

UNIVERSIDADE DE BRASÍLIA - UnB UNIVERSIDADE FEDERAL DA PARAÍBA - UFPB

UNIVERSIDADE FEDERAL DO RIO GRANDE DO NORTE - UFRN

Programa Multiinstitucional e Inter-regional de Pós-graduação em Ciências Contábeis

GERENCIAMENTO DE IMPRESSÃO: UMA ANÁLISE SOBRE A UTILIZAÇÃO DE RECURSOS GRÁFICOS NOS RELATÓRIOS DE COMPANHIAS ABERTAS BRASILEIRAS

KEYLLA DENNYSE CELESTINO DA SILVA

BRASÍLIA - DF

2016 
UNIVERSIDADE DE BRASÍLIA - UnB

\section{Reitor: \\ Professor Dr. Ivan Marques de Toledo Camargo}

Vice-Reitor:

Professora Dra. Sônia Nair Báo

Decano de Pesquisa e Pós-Graduação:

Professor Dr. Jaime Martins de Santana

Diretor da Faculdade de Economia, Administração e Contabilidade:

Professor Dr. Roberto de Goes Ellery Junior

Chefe do Departamento de Ciências Contábeis e Atuariais:

Professor Dr. José Antônio de França

Coordenador Geral do Programa Multi-institucional e Inter-regional de Pós Graduação em Ciências Contábeis da UnB, UFPB e UFRN

Professor Dr. Rodrigo de Souza Gonçalves 


\begin{tabular}{|c|c|}
\hline $\begin{array}{c}\text { UnB } \\
\text { Universidade } \\
\text { de Brasilia }\end{array}$ & $\begin{array}{c}\text { UFPB } \\
\text { UNIVERIDADE FEDERAL } \\
\text { DA PARAIBA }\end{array}$ \\
UNIVERSIDADE FEDERAL DO \\
RIO GRANDE DO NORTE
\end{tabular}

KEYLLA DENNYSE CELESTINO DA SILVA

\section{GERENCIAMENTO DE IMPRESSÃO: UMA ANÁLISE SOBRE A UTILIZAÇÃO DE RECURSOS GRÁFICOS NOS RELATÓRIOS DE COMPANHIAS ABERTAS BRASILEIRAS}

Dissertação apresentada como requisito parcial à obtenção do título de Mestre em Ciências Contábeis do Programa Multiinstitucional e InterRegional de Pós-Graduação em Ciências Contábeis da Universidade de Brasília, Universidade Federal da Paraíba e da Universidade Federal do Rio Grande do Norte.

Linha de pesquisa:

Impactos da Contabilidade na Sociedade

Grupo de Pesquisa:

Demonstrações Contábeis

Orientadora:

Prof ${ }^{a}$. Dra. Fernanda Fernandes Rodrigues 
SILVA, Keylla Dennyse Celestino GERENCIAMENTO DE IMPRESSÃO: UMA ANÁLISE SOBRE A UTILIZAÇÃO DE RECURSOS GRÁFICOS NOS RELATÓRIOS DE COMPANHIAS ABERTAS BRASILEIRAS/ Keylla Dennyse Celestino da Silva-Brasília, 2016.

103. p.

Orientador: Prof. Dra. Fernanda Fernandes Rodrigues

Dissertação (mestrado) - Universidade de Brasília. Faculdade de Economia, Administração e Ciências Contábeis e Atuariais - FACE.

Programa Multi-institucional e Inter-Regional de Pós-Graduação em Ciências Contábeis (UnB/UFPB/UFRN).

1. Relatório da Administração 2. Gerenciamento de Impressão 3. Recursos Gráficos 4.Seletividade 5.Melhora ou Realce de Apresentação. I. RODRIGUES, Fernanda Fernandes. II. Universidade de Brasília. 


\title{
GERENCIAMENTO DE IMPRESSÃO: UMA ANÁLISE SOBRE A UTILIZAÇÃO DE RECURSOS GRÁFICOS NOS RELATÓRIOS DE COMPANHIAS ABERTAS BRASILEIRAS
}

Dissertação apresentada como requisito parcial à obtenção do título de Mestre em Ciências Contábeis do Programa Multiinstitucional e InterRegional de Pós-Graduação em Ciências Contábeis da Universidade de Brasília, Universidade Federal da Paraíba e da Universidade Federal do Rio Grande do Norte.

\section{Comissão Avaliadora}

\section{Prof ${ }^{\text {a }}$. Dra. Fernanda Fernandes Rodrigues}

Programa Multiinstitucional e Inter-regional de Pós-graduação em Ciências Contábeis da UNB/UFPB/UFRN

Presidente da Banca

\author{
Prof. Dr. Moisés Ferreira Cunha \\ FACE/UFG \\ Membro Examinador Externo
}

\section{Prof Dr. Adilson de Lima Tavares}

Programa Multiinstitucional e Inter-regional de Pós-graduação em Ciências Contábeis da UNB/UFPB/UFRN

Membro Examinador Interno 
Aos meus pais, exemplo de retidão, amor e cuidado por todo esforço para que eu e meu irmão alcançássemos todos os nossos sonhos. Toda vitória conquistada por nós é antes de vocês! 


\section{AGRADECIMENTOS}

A gratidão é a memória do coração e por aqui há um exageradamente agradecido a muita gente. Primeiramente, sou grata a Deus, que um dia olhou pra mim, tão pequena e me alcançou com a sua graça irresistível. Desde então, tudo que tenho feito tem sido por Ele e para Ele e a conclusão desse trabalho é só mais uma prova do que amor que imerecidamente me tem sido oferecido.

Aos meus pais, Laercio e Gilda, pelo carinho e apoio incondicional a tudo aquilo que me propus a fazer na vida. Vocês, sem nenhum título oficial me ensinaram muito mais do que qualquer área da academia poderá fazer e são meu grande meu amor. Agradeço ainda ao meu irmão, Ysmael, meu primeiro amigo e ser humano mais íntegro que conheço, por nossa amizade, companheirismo, mitagens, e em especial pela ajuda na coleta de dados dessa pesquisa.

Agradeço ao meu melhor super amigo Nelson, que ao fim da minha graduação ocupava unicamente este posto. Posteriormente, como namorado, me incentivou a ingressar no mestrado e agora como esposo me ofereceu todo apoio e paciência desse mundo para que concluísse o curso. Espero a tua companhia mais uma vez, no doutorado e em todos lugares possíveis. Amo você!

À Professora Dra. Fernanda Fernandes Rodrigues, pela paciência e dedicação na orientação desse trabalho. Obrigada pelas várias sugestões, muitos puxões de orelhas e por confiar a mim esse desafio.

Aos professores Moisés Cunha e Adilson Tavares por terem aceitado compor a banca e pelas valiosas contribuições feitas para o enriquecimento da pesquisa.

Aos professores do Programa Multiinstitucional e Inter-Regional de Pós-Graduação em Ciências Contábeis da Universidade de Brasília, Universidade Federal da Paraíba e da Universidade Federal do Rio Grande do Norte: Prof. Dr. Cesar Tibúrcio, Prof. Dr. Bruno Vinícius, Prof. Dra. Fátima Freire e Prof. Dr. Paulo Lustosa, pelo conhecimento transmitido durante as aulas e por contribuírem para o enriquecimento do meu saber. E em especial, agradeço ao Prof. Dr. Rodrigo Gonçalves, que além das aulas, foi muito além do seu papel de professor, pelas palavras de incentivo e calma. Saiba que o levo a partir de agora como referencial da profissional que espero ser um dia.

Agradeço à Inês, Rodolfo e Sara pela presteza, disposição e boa vontade de atender às muitas demandas apresentadas nesses dois anos. Vocês fazem parte da vitória de cada aluno desse programa! Também aproveito para deixar meu obrigada ao Eugênio, que desde a graduação, tem me dado palavras de encorajamento e me auxiliado em tudo que precisei e mais um pouco. E um 
agradecimento especial ao Prof. Msc. Cláudio Santana, meu primeiro orientador e primeira pessoa a apostar que estaria aqui hoje, pelos muitos conselhos e exemplos!

Aqui deixo também o agradecimento mais exagerado aos melhores colegas mestres que eu poderia ter: Mestre Afonso, Mestre Eduardo, Mestre Ricardo e em especial aos Mestres Carlos e Bianca. Vocês dois foram muito mais que amigos e sem a ajuda desinteressada dos dois, eu jamais teria chegado ao final dessa pesquisa. Não tenho nenhuma combinação de palavras que faça jus à gratidão que vocês merecem e tenho em mim. A verdade é que vocês todos tornaram essa jornada muito mais leve com o bom-humor de sempre, a parceria e constante incentivo. Tenho muito orgulho de ter estudado com vocês e de saber que muito mais que contribuições à ciência, vocês fazem diferença no mundo como doutores em humanidade, amizade e respeito.

Meu muito obrigada à equipe da LS Auditores, Andreia, Tio Sergio e Henrique, pelas muitas contribuições ao longo da minha caminhada profissional e pela admiração completamente recíproca que vocês demonstram por mim.

Agradeço ainda à minha irmã do coração, Rhayssa, por todos os anos da amizade mais sincera que eu possuo. Por ter vindo de outro país para ocupar o posto mais que merecido de madrinha e por saber que se pudesse, seria a primeira a estar aqui para comemorar mais essa etapa.

Meu muito obrigada ainda às minhas companheiras de dança que passaram a me acompanhar pela vida, Alyne, Esterzinha e Michelly. Obrigada por terem me apoiado quando troquei os palcos pelos livros, por entenderem as minhas muitas ausências nos últimos tempos e por tantos anos da amizade tão valiosa que me ofertam!

Por fim, meu carinho e gratidão às orações das lindas bailarinas da Igreja Batista Koinonia. Sou grata por terem permitido que compartilhasse com vocês o pouco que sei, por compreenderem a minha falta de tempo e por terem feito com me sentisse tão amada tão rápido. 
"Esta menina tão pequenina quer ser bailarina.

Não conhece nem dó nem ré mas sabe ficar na ponta do pé."

Cecília Meireles 


\section{RESUMO}

O objetivo dessa pesquisa é investigar as evidências de gerenciamento de impressão na forma de seletividade ou melhora de apresentação nos gráficos empregados nos relatórios da administração divulgados por companhias abertas brasileiras no período de 1997 a 2014. Para isso, foram analisados os relatórios de 180 empresas publicados no sítio eletrônico da Comissão de Valores Mobiliários - CVM de onde foram extraídas as informações necessárias para aplicação de testes estatísticos paramétricos e não paramétricos. As variáveis testadas foram: tamanho da empresa, lucratividade, idade, variação no resultado, tamanho do relatório e período de publicação. Os resultados indicaram que existe relação significativa positiva entre a quantidade total de gráficos, gráficos relativos a informações financeiras-chave (lucro líquido, receita líquida e dividendos), gráficos com melhora ou realce de apresentação e o desempenho financeiro da empresa, sinalizando a possibilidade de gerenciamento de impressão nos relatórios analisados. Também foi constatada relação com a idade da empresa e que nos anos iniciais do período de análise as empresas empregavam menos gráficos para divulgar informações financeiras em seus relatórios. Quanto às limitações da pesquisa, é preciso levar em consideração que os resultados indicativos de infidelidades gráficas podem ser resultado do despreparo ou desatenção dos elaboradores das informações, o que não foi abordado por este estudo.

Palavras-Chave: Relatório da Administração - Gerenciamento de Impressão - Recursos Gráficos - Seletividade - Melhora ou Realce de Apresentação 


\begin{abstract}
The purpose of this study is to investigate the evidence of impress management through selectivity or presentational enhancement on graphs used in the annual reports of Brazilian companies during 1997 and 2014. For this, the reports of 180 companies published on the website of Comissão de Valores Mobiliários - CVM, from where the needed information for the parametric and nonparametric test has been taken. The tested variables were firm size, profitability, firm age, change on result, report size, and period of publication. The results indicate a positive association between the total number of graphs, graphs reporting key financial variables (profit, net income and dividends), graphs with presentational enhancement and firm performance, which is a sign of impress management. It has also been found associated with firm age. During the first years of the investigated period, companies used fewer financial graphs in their reports. The limitations of this study are on the fact that it should be taken into consideration that the results indicating graph infidelities may be a result of unpreparedness or lack of attention on the part of the report preparation, which has not been investigated on this research.
\end{abstract}

Key-Words: Annual Reports - Impression Management - Graphs - Selectivity Presentational Enhancement 


\section{LISTA DE FIGURAS}

Figura 1 - Práticas de Gerenciamento de Impressão.................................................................32

Figura 2 - Distorção de Medidas de Gráficos........................................................................... 43

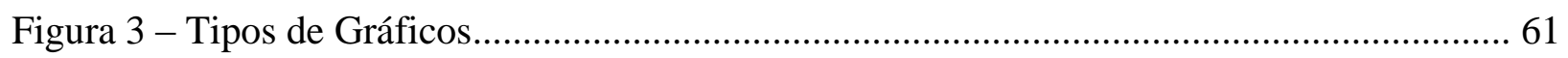

Figura 4 - Tipos de Realce de Apresentação.......................................................................62 


\section{LISTA DE TABELAS}

Tabela 1 - Quantidade de Empresas e Setor de Atuação .59

Tabela 2 - Seleção da Amostra .59

Tabela 3 - Quantidade de empresas e ano de concessão do registro. 60

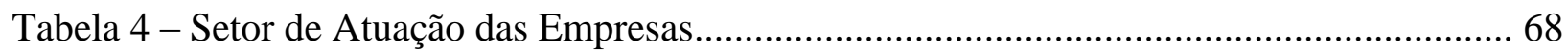

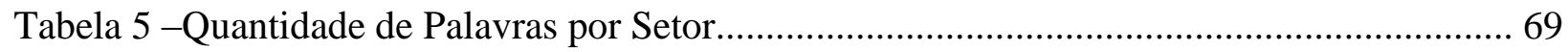

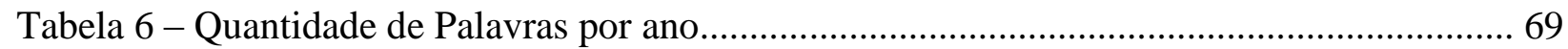

Tabela 7 - Quantidade de Recursos Visuais por Ano................................................................. 71

Tabela 8 - Quantidade de Recursos Visuais por Setor de Atuação.......................................... 71

Tabela 9 - Quantidade de Gráficos por Desempenho .......................................................... 72

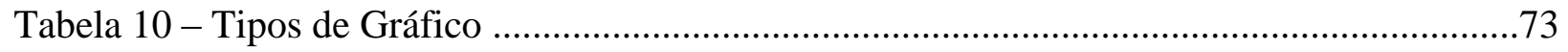

Tabela 11 - Gráficos com Realce ou Melhora de Apresentação ................................................75

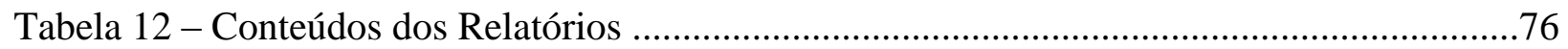

Tabela 13 - Conteúdos dos Gráficos por Setor de Atuação ....................................................77

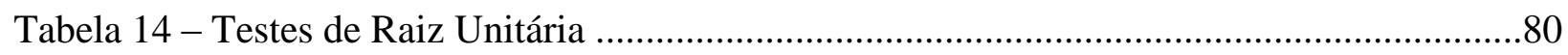

Tabela 15 - Matriz de Correlação Modelo 1 -VFC .....................................................................81

Tabela 16 - Matriz de Correlação Modelo 2 -GRMA ….............................................................81

Tabela 17 - Resumo Relatórios Gráficos x Desempenho .........................................................82

Tabela 18 - Resultados da Regressão das Hipóteses 2 e 3 ....................................................83

Tabela 19 - Resultados da Regressão da Hipótese 4 ...........................................................83

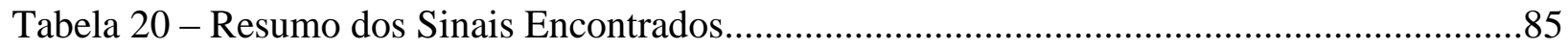




\section{LISTA DE QUADROS}

Quadro 1- Tipos e Causas de Distorções Gráficas.....................................................................45

Quadro 2 - Conteúdos Principais e Específicas .......................................................................63

Quadro 3 - Descrição das Variáveis Independentes .............................................................66

Quadro 4 - Resultados das Hipóteses da Pesquisa ..............................................................83 


\section{LISTA DE ABREVIATURAS}

3D - Três Dimensões

ADF - Dickey-Fuller Aumentado e

ADR -American Depositary Receipts

BM\&FBovespa - Bolsa de Valores de São Paulo

CEO - Chief Executive Officer

CEB - Companhia Energética de Brasília

CPA - Certified public accountant

CSR - Corporate Social Responsibility

CVM - Comissão de Valores Mobiliários

FIV - Fator de Inflação da Variância

GDI - Graphical Distortion Index

IPO - Initial Public Offering

ISE - Stanbul Stock Exchang

KFV - Key Financial Variables

LLC - Levin, Li e Chu (LLC)

LnATIVO - Logaritmo Natural do Ativo da Empresa

LnI - Logaritmo Natural da Idade da Empresa

MQO - Mínimos Quadrados Ordinários

NYSE - Bolsa de Nova York

PCT - Participação de Capital de Terceitos

PP - Phillips -Perron

RA - Relatório da Administração

ROA - Retorno sobre o Ativo

RSPL - Retorno sobre o Patrimônio Líquido

SUR PSCE - Seemingly Unrelated Regression Panel Corrected Standard Errors

T- Período de Tempo

TAMR - Tamanho do Relatório

VFC - Variáveis Financeiras-Chave

VR - Variação do Resultado 


\section{SUMÁRIO}

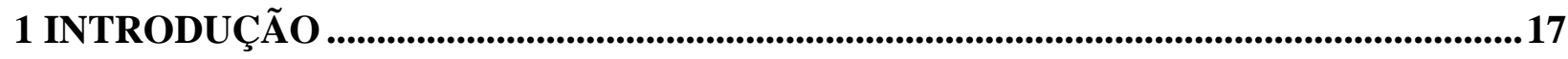

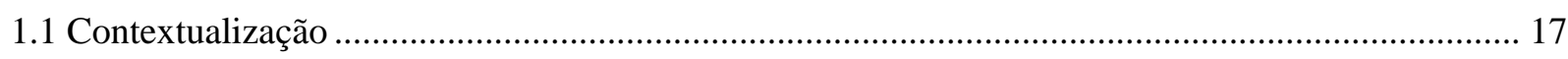

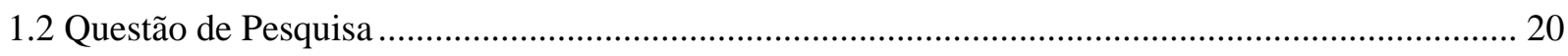

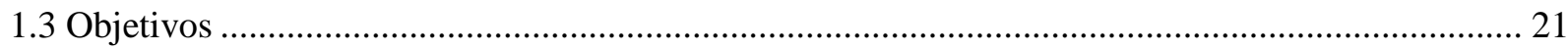

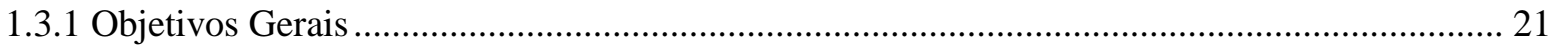

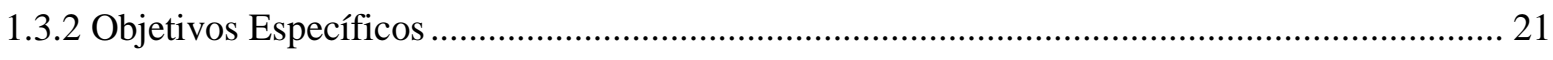

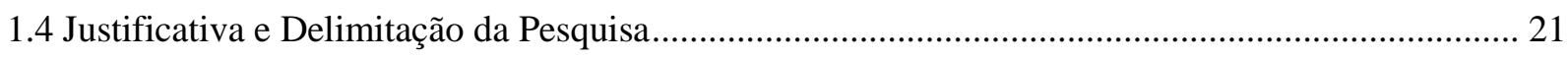

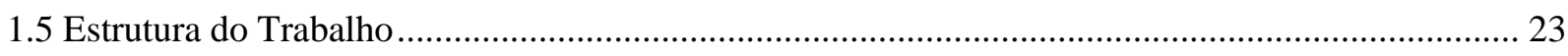

2 REFERENCIAL TEÓRICO .....................................................................................24

2.1 Teoria da Evidenciação Voluntária e Gerenciamento de Impressões ............................................. 24

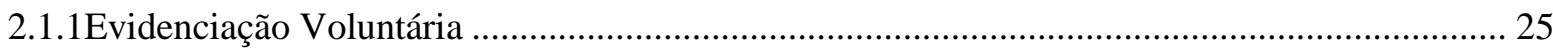

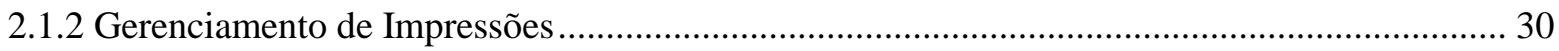

2.2 Relatório da Administração e a Utilização de Recursos Gráficos .................................................... 37

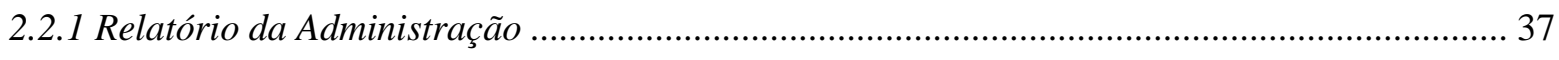

2.2.2 Utilização de Recursos Gráficos nos Relatórios da Administração ........................................ 41

2.3 Pesquisas Empíricas Anteriores: Relação entre a utilização de gráficos e o desempenho financeiro 49

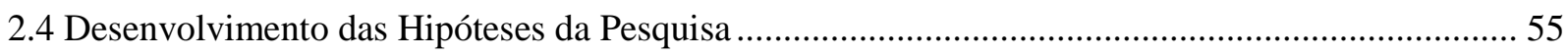

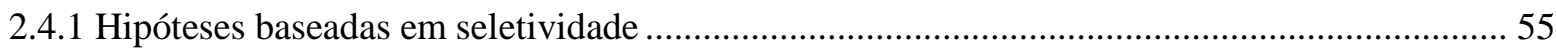

2.4.2 Hipóteses relativas à Melhora de Apresentação .................................................................... 56

3 PROCEDIMENTOS METODOLÓGICOS .........................................................................5 58

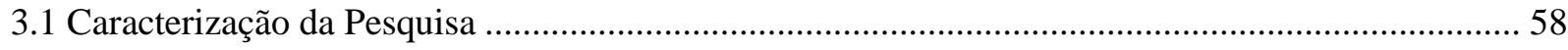

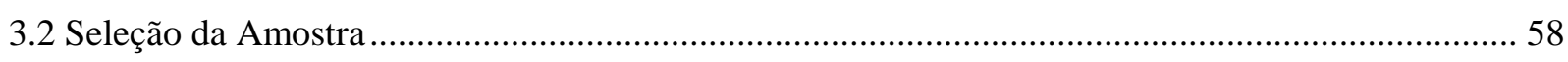

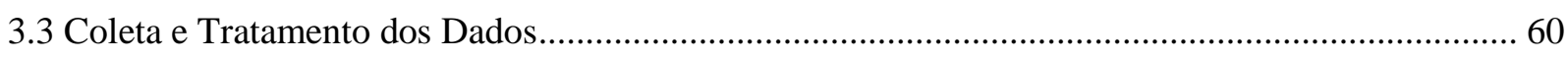

3.4 Análise da Seletividade Gráfica e Melhora da Apresentação............................................................ 64

3.4.1 Variáveis Independentes e Modelos Econométricos ................................................................... 65

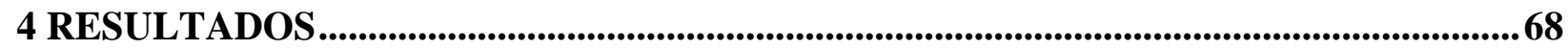

4.1 Caracterização das Empresas e Análise Descritiva dos Relatórios .................................................. 68

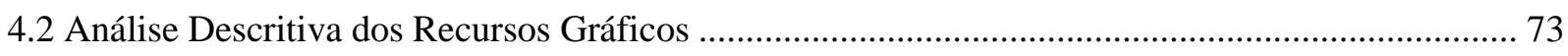

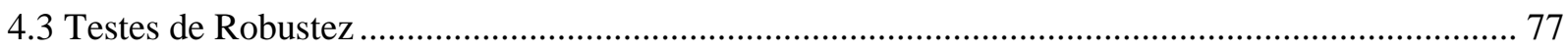

4.4 Resultados da Significância dos Modelos e Hipóteses de Pesquisa ............................................... 81

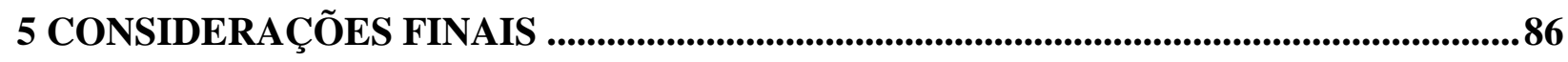

5.1 Contribuições, Limitações e Sugestões para Pesquisas Futuras ...................................................... 88

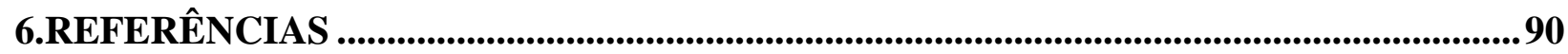

APÊNDICE A - Amostra de Empresas para Análise................................................................100 


\section{INTRODUÇÃO}

\subsection{Contextualização}

Diante do processo de globalização do mercado de capitais e de uma procura maior dos investidores por esses mercados, houve um acréscimo também na necessidade das companhias divulgarem informações seguras e tempestivas que possibilitem ao usuário avaliar a sua condição financeira, o desempenho dos negócios, o perfil e as práticas de gerenciamento de risco (DANTAS et al, 2004).

Em face disso, existe a possibilidade da evidenciação ocorrer tanto de forma voluntária quanto compulsória. Araújo Neto et al. (2008) apontam que os órgãos de classe têm emitido resoluções e pronunciamentos que determinam situações de obrigatoriedade de evidenciação, bem como a forte atuação do governo na regulamentação das informações que devem ser evidenciadas.

No caso das companhias abertas, Ghanbari et al (2016) afirmam que a evidenciação das informações financeiras é vital para obtenção de um desempenho desejável no mercado de capitais, e que investidores reagem negativamente ao se depararem com informações assimétricas reportadas. Existe então, uma tendência dessas empresas a evidenciar as informações de forma mais adequada para possibilitar a captação de recursos nesses mercados. No entanto, questiona-se a credibilidade da evidenciação voluntária quando esta pode estar sendo utilizada para atender a interesses específicos dos gestores e instituições. Muitas vezes, a informação divulgada tem o propósito de melhorar ou manter a imagem organizacional e sua legitimidade, a fim de garantir o controle do status da entidade e sua existência, o que é feito através do gerenciamento de impressão (impression management) (WILLS, 2008).

Este termo vem da psicologia social e está principalmente voltado para o comportamento individual, mas foi adaptado pela academia para ser aplicado ao contexto corporativo referindo-se, portanto, à manipulação das ações ou informações a fim de afetar a percepção dos que as recebem (MOHAMED et al, 1999). Rodrigues (2012) aponta que as primeiras pesquisas abordando algum tipo de gerenciamento contido nos relatórios da administração identificaram gerenciamento dos números contábeis (earnings management), e 
só mais recentemente o gerenciamento de impressões passou a ser objeto de estudo mais frequente na literatura, onde tem se verificado a manipulação das informações apresentadas com a finalidade de criar uma impressão que não corresponde à real situação econômicofinanceira das empresas. Pode-se afirmar, então, que o gerenciamento de impressão nos relatórios anuais ocorre quando existe a intenção de causar uma reação favorável perante os acionistas, governos e demais indivíduos em relação a uma entidade ou gestor (SOUZA, 2013).

Para Beattie e Jones (2000a), o gerenciamento de impressão pode ocorrer de diversas maneiras, como por exemplo, através da manipulação do conteúdo e da sintaxe das narrativas contábeis. Boudt e Thewissen (2015) pontuam que estruturas narrativas são usadas como veículo de gerenciamento de impressão e destacam a presença desse fenômeno nas cartas dos CEOs (chief executive officer), verificando em seu estudo, por exemplo, um número maior de palavras consideradas positivas em detrimento de palavras negativas. Também identificaram uma maior incidência de palavras com viés positivo nas páginas finais dos documentos. Tais fatos não ocorrem por acaso, mas são, nesse caso, um reflexo do cuidado das estratégias de escrita empregadas pelos CEOs com finalidade de provocar a melhor exposição possível.

Diante disso, questiona-se se o ambiente do disclosure voluntário é dirigido por um desejo dos gestores e preparadores dos relatórios das companhias de se apresentarem ao público e usuários das suas informações através de uma ótica favorável (JONES; SLACK, 2011). Cunha e Silva (2009) destacam que nesse ambiente, uma das formas de comunicação das organizações são as demonstrações contábeis. Estas enviam a mensagem sobre a estrutura financeira da empresa em determinado momento e são utilizadas para análise e tomada de decisão, logo também estão sujeitas a serem impactadas por diferentes tipos de gerenciamento de impressões.

Entre os demonstrativos exigidos por lei, destacam-se os Relatórios da Administração e Notas Explicativas, que possuem enfoque narrativo e são objeto de estudos com ênfase na análise de conteúdo e formato de apresentação. No caso específico do Relatório da Administração, Silva et al. (2006) acreditam que por ser menos técnico e mais descritivo que os outros documentos, tem um forte poder de comunicação, podendo prestar conta dos atos praticados e apresentar expectativas sobre desempenhos futuros.

Rowbottom e Lymer (2010) colocam que apesar dos usuários mais experientes utilizarem os Relatórios da Administração principalmente para analisarem detalhadamente 
dados financeiros, a crescente disponibilidade de acesso a essas informações permite que as narrativas provejam uma fonte de informações gerais sobre as empresas tanto para os empregados quanto para um público maior e, que não estaria disponível de outra forma.

Assim, por saberem que a informação financeira bem apresentada tem impacto positivo na imagem de suas companhias e é capaz de influenciar decisões de investimento, cada vez mais, os gestores têm utilizado recursos visuais como gráficos, ilustrações e tabelas em seus relatórios anuais. Diz-se que esses recursos são capazes de enfatizar as informações que estão sendo reportadas, poupar tempo de análise de dados, além de quebrar as barreiras de linguagem, já que são universalmente compreendidos (MATHER et al, 1996).

Apesar de o emprego dos diversos recursos visuais propiciar maior clareza na exposição das informações apresentadas ao usuário, Beattie e Jones (2008a) sintetizam seis razões principais para explicar a predileção das companhias por utilizarem gráficos financeiros no lugar de tabelas ou conteúdos narrativos.

Primeiramente, os gráficos permitem que os gestores apresentem a informação de maneira flexível e umas das explicações para isso é o fato de não haver regulação existente sobre a utilização desses recursos. Em segundo lugar, os gráficos são visualmente atrativos e reforçam as informações com a utilização de cores. E em terceiro, os gráficos são ferramentas de resumo e destacam indicadores chaves das empresas. Além disso, os gráficos atuam de tal forma que as informações reportadas por eles são compreendidas mais rapidamente devido às capacidades cognitivas humanas. Em quinto, recursos gráficos são memoráveis e fixados de maneira mais eficiente que informações puramente numéricas. E, por fim, gráficos são democráticos: eles se comunicam com usuários da informação mais e menos sofisticados e ainda independem da língua utilizada, sendo compreendidos internacionalmente.

No entanto, o formato e apresentação de recursos gráficos também estão sujeitos a manipulações, e a comunicação através deles só será eficiente se estes forem devidamente preparados sem nenhum viés. Beattie e Jones (1992) destacam três tipos de infidelidades no que diz respeito à preparação de gráficos: seletividade, melhora ou realce da apresentação e distorção de medidas. A primeira ocorre, por exemplo, quando uma empresa decide deliberadamente evidenciar informações positivas e deixa de lado variáveis que indicariam informações desfavoráveis. A melhora da apresentação, por sua vez, acontece quando há 
manipulação do design, formato ou até angulação do gráfico, como por exemplo, utilização de cores incoerentes e emprego inapropriado de indicadores em três dimensões. Por fim, as distorções de medidas, que segundo Wills (2008) são as mais encontradas e estudadas na literatura, correspondem àquelas decorrentes da desproporcionalidade das medidas do gráfico e números representados.

Assim, é possível que os usuários dos relatórios anuais de companhias abertas brasileiras estejam sujeitos a recepcionar informações distorcidas apresentadas em gráficos preparados inadequadamente, já que as organizações podem estar mais preocupadas com a estética desses recursos do que com a informação reportada por eles ou estejam, de fato, interessadas na manipulação da impressão transmitida (NASCIMENTO et al, 2013), além da possibilidade ainda, do despreparo dos que elaboram essas informações. Nesse sentido, existe a possibilidade de que o emprego de gráficos, bem como possíveis distorções de apresentação estejam relacionadas a características da própria empresa, como o desempenho financeiro (BEATTIE;JONES, 2002) ou ainda ao seu tamanho (UYAR, 2011).

\subsection{Questão de Pesquisa}

Diante do exposto, questiona-se a possibilidade da existência de gerenciamento de impressão nos recursos gráficos empregados nos Relatórios da Administração de companhias abertas brasileiras. Assim, o problema deste estudo está em verificar se os gráficos empregados nesses relatórios possuem algum viés de seletividade ou melhora de apresentação no que se refere à quantidade de gráficos utilizados, ao conteúdo reportado por eles e às distorções de apresentação. Nesse sentido, esse estudo se propõe a responder ao seguinte questionamento: Quais as evidências de gerenciamento de impressão (seletividade e melhora de apresentação) nos gráficos empregados nos Relatórios da Administração divulgados por companhias abertas brasileiras em relação ao seu desempenho financeiro no período de 1997 a 2014 ? 


\subsection{Objetivos}

\subsubsection{Objetivos Gerais}

Verificar e analisar evidências de gerenciamento de impressão nos gráficos empregados nos Relatórios da Administração divulgados pelas companhias abertas brasileiras em relação ao seu desempenho financeiro no período de 1997 a 2014.

\subsubsection{Objetivos Específicos}

Para atingir o objetivo principal proposto, faz-se necessário alcançar os seguintes objetivos específicos:

a) Levantar a quantidade e formas gráficas empregadas nos RAs analisados.

b) Classificar as informações gráficas segundo o conteúdo reportado.

c) Identificar parâmetros para mensurar os padrões de seletividade dos gráficos contidos nos RAs.

d) Identificar a presença de realce de apresentação nos gráficos levantados.

\subsection{Justificativa e Delimitação da Pesquisa}

Esse trabalho justifica-se pela relevância da informação contábil no que tange à tomada de decisões no mercado de capitais e pela escassez de estudos com enfoque no gerenciamento de impressões na literatura, já que esta abordagem é considerada uma extensão dos estudos sobre gerenciamento de resultado (earnings management). Quanto à relevância dos relatórios da administração, as instituições devem divulgar informações qualitativas e quantitativas a fim de que os usuários alcancem a compreensão das atividades desenvolvidas, bem como seus riscos, observando aspectos de tempestividade, detalhamento e relevância necessários. Para isso, além das demonstrações contábeis, as empresas divulgam informações complementares por meio de relatórios qualitativos. 
Nesse contexto, Dalmácio e Paulo (2004) afirmam que dentre os demonstrativos exigidos pela Lei das Sociedades Anônimas, apenas o Relatório da Administração e as Notas Explicativas permitem uma maior evidenciação da situação social e política da empresa. Pen Rose (2007) coloca o Relatório da Administração como sendo utilizado pelos acionistas e demais integrantes das organizações por conter as informações financeiras básicas e as opiniões da gestão sobre as operações de anos anteriores, bem como perspectivas futuras da empresa, sendo, portanto um elemento utilizado para tomar decisões de compra, manutenção ou venda de ações.

Nesse sentido, destaca-se também a carência de pesquisas voltadas para o conteúdo dos RAs de companhias abertas brasileiras, e mais ainda no que diz respeito à presença de recursos visuais, apesar de alguns autores internacionais já haverem explorado essa temática, a exemplo de Steinbart (1989) e Beattie e Jones (1992). Há que se destacar que com o passar dos anos, os RAs têm apresentado mudanças no seu formato, exibindo mais recursos visuais, como gráficos e tabelas, que são usados por simplificarem e sintetizarem as informações, facilitando assim o entendimento (NASCIMENTO et al., 2013). Beattie e Jones (1992) apontam estudos que comprovam que os RAs não costumam ser lidos integralmente e que, nessas circunstâncias, os gráficos contidos nesses relatórios, por serem visualmente atrativos, têm mais chance de serem notados e lembrados posteriormente pelos leitores.

Beattie e Jones (2008a) pontuam que, surpreendentemente, os gráficos não são auditados nem são objetos de regulação na maioria dos países. Nos Estados Unidos e no Reino Unido, por exemplo, os pronunciamentos regulamentares apenas exigem do auditor que ele revise seções adicionais dos relatórios anuais. Isso significa que ainda que essa flexibilidade estimule a criatividade e inovação dos gestores, as oportunidades de gerenciamento de impressão e infidelidade gráfica aumentam significativamente. O gerenciamento de impressão sugere também que os gestores buscam utilizar gráficos de maneira oportunista para apresentar uma visão favorável do desempenho da empresa e criar uma imagem mais favorável do que aquela que ela teria através do desempenho real.

Além disso, Miranda et al (2008) afirmam que a utilização de recursos gráficos torna a informação mais interessante e facilita a assimilação dos usuários, por conta do apelo visual e maior facilidade de compreensão. Em contrapartida, os mesmos autores enunciam que os recursos gráficos podem proporcionar uma mudança na percepção de um relatório contábil. 
Diante de tal abordagem, essa pesquisa contribui para literatura existente por alcançar um tema pouquíssimo explorado no país, com destaque para as pesquisas realizadas por Miranda et al (2008), Nascimento et al (2013) e Penteado (2013). Ela avança ao levantar hipóteses baseadas em pesquisas anteriores no âmbito internacional, que sendo ou não refutadas poderão contribuir com um embasamento teórico das pesquisas nacionais e permitir que a literatura avance no que tange às diferenças culturais e o impacto delas na evidenciação financeira, atendendo a uma carência de pesquisa na área em países em desenvolvimento apontada por Beattie e Jones (2008a). Além disso, destaca-se o fato de a amostra ser composta por todas companhias abertas brasileiras que ativaram cadastro na CVM em 1997 ou antes e possuíam todos os relatórios disponibilizados no sítio da instituição até 2014, ou seja, são considerados todos os relatórios disponíveis numa série temporal de 18 anos, o que proporciona uma análise mais consistente em relação às pesquisas empíricas anteriores realizadas no país que contavam com amostras consideravelmente menores.

Assim, diante dessas mudanças no formato dos RAs e da carência de estudos na comunidade acadêmica no Brasil acerca da utilização de recursos visuais nesses relatórios (RODRIGUES, 2012), espera-se que essa pesquisa possa contribuir com a literatura existente no país. E sabendo que a comunicação contábil incorre no risco de ser prejudicada porque os preparadores dos relatórios da administração podem manipular a apresentação dos recursos gráficos de forma a beneficiar os interesses da gestão, acredita-se que o tipo de estudo aqui proposto possa evidenciar possíveis falhas no que tange à elaboração dos RAs divulgados pelas empresas com registro na CVM, tanto em seu conteúdo quanto forma de apresentação, provocando a reflexão quanto a medidas que podem ser tomadas para fiscalizar e garantir a correta utilização desses recursos nos relatórios de empresas brasileiras.

\subsection{Estrutura do Trabalho}

Esta pesquisa encontra-se estruturada da seguinte forma:

- Capítulo 1 - traz a contextualização, a questão da pesquisa, os objetivos (geral e específicos), a justificativa da pesquisa, e a estrutura da pesquisa.

- Capítulo 2 - apresenta o referencial teórico, abrangendo as teorias da evidenciação voluntária e do gerenciamento de impressões, bem como aspectos acerca do Relatório 
da Administração e utilização dos recursos gráficos, além das pesquisas anteriores realizadas.

- Capítulo 3 - descreve a metodologia proposta para a pesquisa, no que se refere à seleção da amostra, coleta e tratamento dos dados.

- Capítulo 4 - traz os resultados da pesquisa quanto à caracterização das empresas, análise descritiva dos relatórios e testes das hipóteses levantadas.

- Capítulo 5 - aponta as considerações finais do estudo, os principais resultados encontrados e reflexão sobre eles, as limitações da pesquisa e também sugestões para trabalhos futuros.

\section{REFERENCIAL TEÓRICO}

Esta seção aborda primeiramente a teoria que suporta a discussão dessa pesquisa e as questões relativas ao gerenciamento de impressões nas narrativas contábeis. A segunda parte do capítulo traz considerações acerca do Relatório da Administração e é apresentado o panorama no qual as pesquisas sobre a utilização de recursos gráficos encontram-se. Por fim, são apontadas pesquisas realizadas anteriormente no exterior e no Brasil sobre o assunto.

\subsection{Teoria da Evidenciação Voluntária e Gerenciamento de Impressões}

Melo et al (2007) afirmam que ao se analisar o conjunto total do disclosure de uma empresa, deve ser levado em consideração que não está inserida nele apenas a porção de informação regulada por lei, mas também toda informação que seja julgada útil para tomada de decisões dos stakeholders. Dantas, Zendersky e Niyama (2004) ressaltam a importância que deve ser dada ao papel desempenhado pela evidenciação ou disclosure dentro do contexto dos objetivos da Contabilidade, no que se refere ao fornecimento de informações úteis aos usuários para a tomada de decisão.

Hendriksen e Van Breda (1999, p. 524) afirmam que a quantidade de informação divulgada depende da sofisticação do leitor que a recebe, e que a evidenciação das informações 
deve ser adequada, justa e completa. Os autores elencam entre as formas mais comuns de evidenciação, a apresentação das demonstrações contábeis, informação entre parênteses, notas explicativas, os quadros e demonstrativos suplementares, os comentários do auditor e o relatório da administração.

No Brasil, a Lei $n^{\circ} 11.638 / 07$, que altera a Lei $n^{\circ}$ 6.404/76 que dispõe sobre as sociedades por ações e sua contabilidade, elenca algumas informações que obrigatoriamente devem ser divulgadas pelas companhias abertas, como as demonstrações contábeis em sua íntegra - Balanço Patrimonial, Demonstração do Resultado do Exercício, Demonstração das Mutações do Patrimônio Líquido, Demonstração dos Fluxos de Caixa e Notas Explicativas. No entanto, existe uma demanda maior por parte dos usuários das informações que aparentemente não é atendida unicamente pela divulgação das demonstrações contábeis. Então, as companhias passam a divulgar essas informações adicionalmente nas próprias Notas Explicativas ou no Relatório da Administração.

Assim, percebe-se que o disclosure de uma empresa possui um conjunto de informações onde não está contida apenas a parte de informações que é exigida por lei, mas também toda porção de informações que são necessárias para a tomada de decisão dos stakeholders. Isso significa que o disclosure além de compulsório, também se dá de forma voluntária com a divulgação de informações não exigidas por lei, mas que oferecem maior transparência no âmbito coorporativo. (LIMA, 2007). Ghanbari et al (2016) pontuam que quando novas informações sobre a situação da companhia no mercado são divulgadas, elas são analisadas pelo usuário da informação e influenciam o seu comportamento, impactando o volume de transações e flutuações de preços

\subsubsection{Evidenciação Voluntária}

Problemas informacionais e conflitos de interesse podem interferir na eficiência do mercado de capitais, quando de alguma maneira impactam a correta alocação de recursos. Dessa forma, o disclosure é peça importante para o funcionamento de um mercado de capitais eficiente ao auxiliar o processo decisório de investidores (HEALY;PALEPU, 2001).

Segundo Korne Schiller (2002), o modelo básico da evidenciação voluntária mostra que em uma situação de equilíbrio, as empresas deveriam divulgar todas as suas informações 
privadas. Isso porque o preço de mercado das empresas depende das expectativas dos investidores sobre os resultados futuros. Os autores explicam que se nenhuma empresa divulga informações privadas, as expectativas dos investidores se mantêm simétricas e os preços permanecem constantes. No entanto, uma vez que uma empresa decida divulgar informações adicionais, há uma revisão de todos os preços do mercado e o valor das empresas que não divulgam cai em relação a esta, induzindo as demais empresas a divulgarem também, o que eleva o seu preço em relação àquelas que não divulgaram. Esse movimento daria início a um ciclo que tende ao equilíbrio das informações divulgadas até que todas as informações privadas das companhias estejam disponíveis no mercado.

Nesse sentido, o disclosure voluntário é toda informação divulgada além daquela exigida legalmente e representam escolhas livres por parte dos gestores das empresas ao providenciarem informações contábeis e adicionais relevantes para a tomada de decisão dos usuários, além de poderem ser classificadas em três grupos (MEEK;ROBERTS;GREYS, 1995). Os dois primeiros grupos são os de divulgação estratégica e financeira, que são obviamente relevantes para os investidores e discutidos amplamente na literatura. $\mathrm{O}$ terceiro grupo, que diz respeito às informações não-financeiras, estão direcionados à contabilidade social das empresas e a grupos determinados de acionistas. Assim, as variáveis que afetam o disclosure voluntário variam conforme o tipo de evidenciação pretendida.

Angonese et al (2014) apontam o fato de que a prerrogativa que o gestor possui de escolher entre divulgar ou não determinada informação diferencia a informação voluntária da informação compulsória. Assim argumenta-se que a evidenciação voluntária envia sinais ao mercado capazes de influenciar em mudanças no valor presente das empresas e de suas ações (ALOTAIBI; HUSSAINEY, 2016). Pode-se dizer, então, que o nível da correta alocação de recursos no mercado de capitais depende diretamente da credibilidade das informações divulgadas, já que os gestores podem reportar informações para atender a interesses pessoais.

Nesse cenário, Healy e Palepu (2011) apontam dois mecanismos para aumentar a credibilidade do disclosure voluntário. Primeiramente, a existência de intermediários, como analistas financeiros e auditores, que assegurem as informações divulgadas e em segundo, a própria confirmação de previsões através da análise dos relatórios financeiros que reportem as realizações da empresa. No entanto, os autores ressaltam que esses mecanismos são mais eficientes caso haja a aplicação de penalidades para os gestores que divulgarem informações 
provadas falsas no futuro. Isso é possível, por exemplo, através da comparação das informações divulgadas previamente com expectativas de desempenho e os valores de realização destes. Ressalta-se então que, a atuação do sistema legal e regulatório possui importante papel na asseguração da credibilidade do disclosure ao definir tais penalidades.

Apesar dos aspectos práticos da evidenciação, Dye (2001) afirma que leitores novatos na literatura que trata do disclosure podem afirmar de início que tal assunto ainda não mereceu o status de Teoria. No entanto, apesar de acreditar que tal visão é parcialmente correta, pois realmente não há discussão teórica suficiente acerca da evidenciação compulsória, o autor acredita que há sustentação para estabelecer uma teoria de evidenciação voluntária. Ele afirma que a Teoria da Evidenciação Voluntária é um caso especial da Teoria dos Jogos, com a seguinte premissa: qualquer entidade com a opção de divulgar informações o fará divulgando informações favoráveis à entidade e não divulgando informações desfavoráveis.

No Brasil, Salotti e Yamamoto (2005) também relacionam a evidenciação voluntária à Teoria dos Jogos, que podem ser solucionados de diversas maneiras com base em três estratégias principais: dominante, teoria do equilíbrio de Nash e baseadas no conceito de "maximium". Os jogos seriam um conjunto de regras, onde os jogadores, suas ações e informações disponíveis são definidos. Com base nessa Teoria, o processo de divulgação pode ser entendido como um jogo de dois jogadores (firma versus investidores) e assim poderia fornecer modelos para a avaliação do conhecimento dos investidores, que tomam decisões baseadas nas informações divulgadas pelas empresas.

Nesse ponto, Dye (2001) aponta uma questão interessante onde a teoria pode ser usada para tomada de decisão: é preciso interpretar o silêncio das empresas assim como o que é divulgado. Em um exemplo simples, o autor sugere considerar o currículo excelente de um candidato a emprego, mas que indique 15 anos de intervalo entre o fim do ensino médio e faculdade. A teoria permite que o contratante infira algumas situações possíveis e indague se o dono do currículo fez outra graduação neste intervalo, se esteve doente, ou até mesmo na prisão. $\mathrm{O}$ autor continua e sugere que tal raciocínio também se aplica à interpretação das informações divulgadas pelas entidades: se uma empresa, repetidamente em seus relatórios destaca informações como "redução de custos" e omite informações sobre seus ganhos, a teoria permite a inferência de que os valores sobre receitas não foram tão satisfatórios. 
Já os autores brasileiros Salotti e Yamamoto (2005) observaram relação entre as três estratégias da Teoria do Jogos e as categorias de evidenciação voluntárias estabelecidas por Verrecchia (2001). Em seu estudo, Verrecchia faz uma síntese dos trabalhos realizados sobre evidenciação classificando-os em: Divulgação Baseada em Associação (Association based disclosure) Divulgação Baseada em Julgamento (Discretionary-based disclosure) e Divulgação Baseada em Eficiência (Efficiency-based disclosure). A primeira delas trata o processo de evidenciação como exógeno e engloba os estudos sobre os efeitos que a divulgação possui sobre o comportamento dos investidores. As pesquisas sobre a ótica da Divulgação Baseada em Julgamento buscam examinar o que motiva a divulgação dos gestores e como estes decidem divulgar suas informações, tratando a divulgação, portanto, como um processo endógeno. E por fim, as pesquisas da última categoria enfocam quais os tipos de divulgação preferidas e mais eficientes quando não há conhecimento prévio das informações.

No Brasil, Murcia e Santos (2009) realizaram estudo com base na modelagem de Verrechia (2001), cujo objetivo foi identificar os fatores que explicam o nível de disclosure voluntário das companhias abertas no Brasil. O nível de disclosure das empresas foi definido a partir de uma métrica composta por seis categorias e 43 subcategorias e a amostra foi composta pelas 100 maiores companhias abertas não-financeiras. Os autores verificaram que as maiores empresas, pertencentes ao setor elétrico, que possuem American Depositary Receipts (ADRs) nos níveis II e III na Bolsa de Nova Iorque (The New York Exchange-NYSE) e que aderem aos níveis diferenciados de governança corporativa da Bolsa de São Paulo (BM\&FBovespa), possuem, em média, um maior nível de disclosure voluntário.

Sob a ótica do que influencia os gestores a divulgar ou não determinadas informações, as pesquisas na área têm tratado de investigar que características da própria empresa motivam o disclosure voluntário. Um dos itens que tem sido frequentemente associado à extensão da evidenciação voluntária é o tamanho da empresa. Como possível explicação, Watts e Zimmerman (1990) afirmam que empresas de maior porte arcam com custos políticos mais altos e que por isso tendem a divulgar mais informações para reforçar a confiança do mercado e reduzir tais custos. Murcia (2009) também pontua que empresas menores são mais sensíveis aos custos de divulgação porque existe uma parcela de custo fixo dentro do disclosure.

Nesse sentido, a maioria das pesquisas tem encontrado relação estatística significativa entre os níveis de evidenciação voluntária e o porte da empresa. Uma das primeiras pesquisas 
na área foi realizada por Chow e Wong-Boren (1987), que investigaram as práticas de disclosure voluntário em 52 companhias listadas no Mexican Stock Exchange. Os autores testaram a relação entre o disclosure e o tamanho da empresa, endividamento e ativos intangíveis tendo encontrado relação significativa apenas na variável tamanho.

Macagnan (2009) identificou fatores que influenciam a extensão da evidenciação de informação voluntária sobre os recursos intangíveis, de empresas listadas na Bolsa Espanhola. Os resultados da pesquisa demonstram que o tamanho, o setor, o endividamento, o grau de internacionalização, os anos de existência e a diferença entre o preço da ação sobre o valor contábil da empresa explicam a maior extensão da evidenciação de informação de recursos intangíveis. Já a rentabilidade, o grau de monopólio e o capital flutuante da empresa podem explicar a menor extensão da evidenciação dessas informações.

Soliman (2013) investigou a associação entre o nível de disclosure voluntário dos relatórios anuais e as características das 50 maiores companhias egípcias listadas no Egyptian Stock Exchange, do setor não financeiro, para o período de 2007 a 2010. As variáveis estudadas foram o tamanho da empresa, tamanho da auditoria, desempenho financeiro e idade da empresa. O autor encontrou relação significativa entre o tamanho da empresa, enquanto o tamanho da auditoria e idade não apresentaram relação.

Na Líbia, Hawashe (2016), por exemplo, investigou empiricamente se existia alguma associação significante entre sete atributos específicos do setor bancário (idade, tamanho, posição de liquidez, lucratividade, participação do governo, participação de capital estrangeiro e ranking comercial) e o nível de evidenciação voluntária nos relatórios anuais. Para isso utilizou modelo de regressão de mínimos quadrados ordinários, apurando que existe associação significante com as variáveis tamanho do banco e o ranking comercial.

Doná et al (2016) analisaram fatores determinantes do conteúdo divulgado no Relatório da Administração de companhias com ações negociadas na BM\&FBOVESPA, do setor consumo cíclico, subsetor comércio, no período de 2008 a 2013. Os fatores analisados foram tamanho da empresa, participação acionária, segmento de governança, retorno sobre o patrimônio líquido e retorno sobre o ativo. Os autores identificaram relação positiva e significante entre o volume de informações contido nos Relatórios da Administração e o 
tamanho, segmento de governança e rentabilidade. Não houve relação estatisticamente significante no caso da participação acionária.

Além do porte da entidade, os aspectos da evidenciação voluntária também têm sido relacionados ao tempo de atuação da empresa. Sob a ótica da teoria da legitimidade, que prevê que a existência da empresa depende da aceitação da sociedade onde ela atua, empresas mais antigas devem apresentar melhor reputação que empresas mais novas, e isso implica na necessidade de preservá-la junto ao mercado. Nesse sentido, Roberts (1992) afirma que características como tamanho da empresa, classificação da indústria e idade podem ser variáveis que tenham alguma influência na divulgação voluntária de informações e podem ser usadas como variáveis de controles. Esse autor encontrou relação significativa entre elas e a divulgação de informações sobre a responsabilidade social de empresas americanas.

Ferchichi e Paturel (2013) examinaram o valor informacional do capital intelectual no mercado financeiro da Tunísia. Os autores analisaram o conteúdo dos relatórios de 50 companhias listadas no Tunisian Stock Exchange divulgados no período de 2006 a 2009 e verificaram que a divulgação voluntária de informações sobre o capital intelectual das empresas é relacionada positiva e significativamente à criação de valor e à variável indicativa da idade da empresa.

\subsubsection{Gerenciamento de Impressões}

Cunha e Silva (2009) apontam que as informações narrativas, além daquelas que apresentam unicamente informações numéricas, têm representado maior percentual no tamanho das demonstrações, destacando-se aí as Notas Explicativas, o Relatório da Administração e o Parecer de Auditoria. No entanto, esse incremento no tamanho dos relatórios anuais, bem como no nível de disclosure voluntário pode sinalizar a probabilidade desses relatórios estarem sendo utilizados para fins de gerenciamento de impressões (WILLS, 2008).

O termo gerenciamento de impressões vem da psicologia e segundo Leary e Kowalski (1990), refere-se ao processo pelo qual os indivíduos tentam controlar a impressão dos que estão ao seu redor formulam sobre eles. Isso porque as impressões que as pessoas possuem sobre os outros implicam na maneira como irão tratá-los e falar sobre eles. Em outras palavras, 
esse termo descreve os esforços que um ator realiza para criar, manter, proteger ou alterar uma imagem apresentada a uma audiência alvo (MENDONÇA; HELAL, 2011).

Esse termo confunde-se com outro conceito da psicologia chamado "self-presentation", no qual os indivíduos além de tentarem manipular a imagem que passam aos demais, também tentam controlar a forma como eles próprios se veem. Nesse sentido, o gerenciamento de impressão é um termo mais amplo, pois ele abrange também a possibilidade de uma terceira parte tentar controlar a imagem de outros indivíduos, podendo ser aplicado a empresas e instituições (LEARY;KOWALSKI, 1990). No mundo corporativo, essa ideia pode estar relacionada à tendência dos gestores e organizações utilizarem o conteúdo reportado de maneira seletiva para apresentarem-se de forma favorável aos interessados nas informações (CUNHA; SILVA, 2009).

Segundo Osma, Guillamón-Saorín e Arts (2010), a teoria da agência apresenta um panorama lógico e sólido para a compreensão do comportamento em que algum tipo de gerenciamento é utilizado para atender a interesses próprios. Esta teoria prevê a relação entre o principal (dono das empresas) e o agente (gestor) como um contrato, onde o primeiro delega funções ao segundo. Eisenhardt (1989) afirma que existem duas abordagens na literatura para esta teoria. A primeira é uma abordagem positivista, na qual os pesquisadores buscam identificar as situações em que podem ocorrer conflitos de interesse entre o principal e o agente, bem como levantar mecanismos de governança coorporativa que possam reduzir um comportamento self-serving do agente. A segunda abordagem é chamada de Principal-Agente e abrange não somente as relações donos/CEOs, mas também empregador/empregado e advogado/cliente, por exemplo. Essa abordagem envolve variáveis, lógica matemática e busca identificar os contratos mais eficientes considerando itens como níveis de incerteza e aversão a risco.

Outras teorias também têm sido utilizadas para explicar as práticas de evidenciação financeira. Entre elas, destaca-se a Teoria do Stakeholder, onde a premissa básica é a criação de valor. A ideia é que gestores devem levar em consideração os interesses legítimos dos indivíduos ou grupos que podem afetar ou ser afetados por suas atividades e objetivos, com a finalidade de criar valor para a companhia (FREEMAN et al, 2004). No caso, as companhias divulgam informações para atender às expectativas de diversos stakeholders, como 
empregados, clientes e governo, de tal forma que se valem do gerenciamento de impressão para manipular as percepções de um grupo particular (MERKL- DAVIES; BRENNAN, 2007).

Alinhada à Teoria dos Stakeholders, está a Teoria da Legitimidade. Merkl-Davies e Brennan (2007) afirmam que sob a luz dessa teoria, existe a noção de um contrato social entre a empresa e a sociedade, na qual as informações divulgadas se propõem a atender às demandas das partes interessadas. Isso explica a seleção dos conteúdos reportados e a divulgação de informações relativas a temas como responsabilidade ambiental e social. Os autores afirmam que as duas teorias se complementam e além delas, ainda relacionam o gerenciamento de impressão à Teoria da Sinalização e a Teoria Institucional. A diferença entre elas está no enfoque das informações, já que enquanto as Teorias da Legitimidade, Stakeholder e Institucional trazem um enfoque maior sobre o desempenho social e ambiental das empresas, a Teoria da Agência e Sinalização abrangem mais os aspectos de desempenho financeiro.

A partir de tais teorias e observando-se o surgimento de conflitos de interesse entre os objetivos do principal e do agente, é de se supor que este último possa manipular informações de maneira a melhorar não só a imagem da instituição, mas também sua própria imagem junto ao ambiente coorporativo. Nesse sentido, Osma, Guillamón-Saorín e Arts (2010) afirmam que a literatura sinaliza a utilização de uma combinação de gerenciamento de impressões e gerenciamento de resultados para tal finalidade, mas existe uma diferença clara entre ambos. Enquanto o primeiro está focado diretamente na manipulação direta dos números divulgados, o gerenciamento de impressões lida com a potencial alteração da apresentação da informação. De qualquer forma, ambos representam sérios riscos de distribuição indevida de capital (OSMA; GUILLAMÓN-SAORÍN, 2011).

Kraemer (2008) afirma que esses mecanismos são ferramentas de um fenômeno chamado contabilidade criativa, que pode ser definida como uma maquiagem da realidade patrimonial da entidade, decorrente da manipulação dos dados contábeis de forma intencional, para se apresentar a imagem desejada pelos gestores da informação contábil.

Entre as razões para que os gestores se vejam tentados a manipular a imagem das companhias, Healy e Wahlen (1999) pontuam como possível motivação para o gerenciamento de resultado a existência de uma diferença muito grande entre o desempenho atual da empresa e a expectativa dos analistas. Já Kraemer (2008) afirma que no gerenciamento de impressão, a 
inclusão ou não de informações pode conduzir o usuário a conclusões equivocadas sobre o passado e as expectativas para o futuro do empreendimento e tal procedimento é evidência da prática de gerenciamento de impressão.

Segundo Jones (2011), isso acontece porque geralmente os relatórios da administração não são objeto dos serviços de auditoria, então acabam proporcionando oportunidade aos gestores de escolherem como os números serão apresentados, dando aos usuários uma determinada impressão sobre os resultados da empresa. É possível verificar na Figura 1 as principais práticas de gerenciamento e que efeitos provocam nos demonstrativos financeiros:

Figura 1 - Práticas de Gerenciamento de Impressão

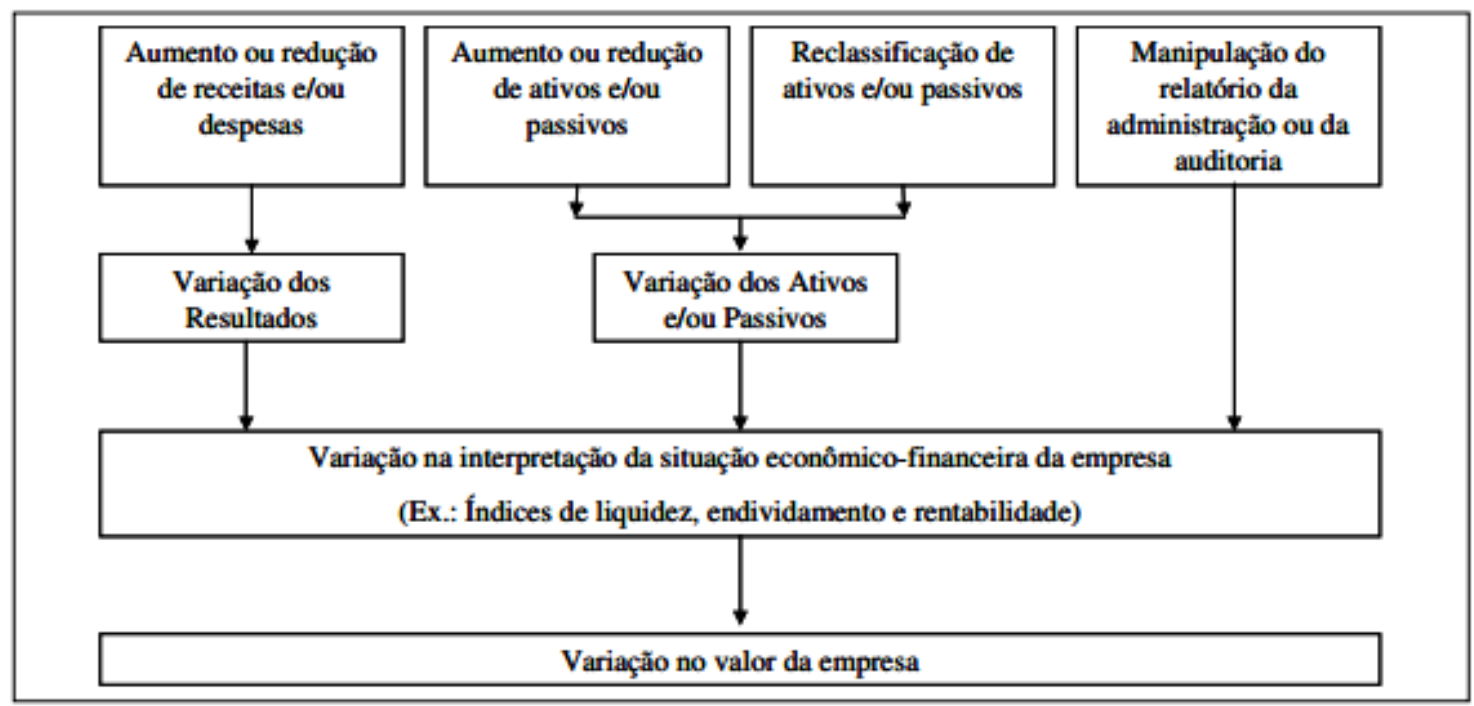

Fonte: Tradução de Blake, Gutiérrez e Salas (1996).

Diante disso, o gerenciamento de impressões tem sido identificado nas situações em que os gestores das organizações produzem e distribuem as informações de forma que afetem as decisões, opiniões e comportamento dos usuários (STANTON; STANTON, 2004). Brennan et al (2009) afirmam que os gestores divulgam os relatórios anuais utilizando termos sintáticos e linguagem mais complexa para dificultar a leitura ao reportarem más notícias. Ou ainda que tendem a demonstrar nas narrativas que os desempenhos inferiores estão relacionados a fatores externos, enquanto que bons resultados devem ser associados a fatores internos

Em outras palavras, o que Brennan et al (2009) apontam é que os gestores gerenciam impressões nas narrativas contábeis e fazem isso com emprego de recursos linguísticos que ofuscam informações sobre o desempenho, especialmente quando este é negativo. Para Beattie e Jones (2000a), entre as diversas formas de gerenciamento de impressão no mundo 
corporativo, além da manipulação de conteúdo e narrativas contábeis, observa-se também a manipulação na forma com que recursos visuais como gráficos e ilustrações são utilizados. Bhana (2009) afirma que os recursos visuais são utilizados para guiar a interpretação do leitor e que fotografias, por exemplo, são empregadas para distraí-los de outras informações nos relatórios bem como prover maior credibilidade às informações reportadas.

Pode-se então apontar duas óticas que resumem as práticas comuns ao gerenciamento de impressões: ocultação e atribuição. A primeira é feita através da omissão ou ofuscação de resultados negativos ou ênfase nos resultados positivos. Já a técnica de atribuição envolve a associação de situações positivas a fatores internos e situações negativas a fatores externos à empresa.

Nesse panorama, Merkl-Davis e Brennan (2007) apontaram seis estratégias de gerenciamento de impressão relacionadas à ocultação e uma à estratégia de atribuição, nas quais são empregadas informações seletivas e diferentes maneiras de divulgação. São elas: i) manipulação da legibilidade ii) manipulação da retórica iii) manipulação temática iv) manipulação visual e estrutural v) comparação de desempenho vi) escolha de indicadores de desempenho e vii) atribuição de desempenho (essa última correspondente à técnica de atribuição).

Diz-se ainda que o Gerenciamento de Impressões possa ser "proativo" ou "protecionista". Se ele for utilizado com a finalidade de fortalecer a imagem de alguma instituição e sua relação com o acionista, o gerenciamento de impressão está sendo realizado de maneira proativa. É o caso, por exemplo, de quando as narrativas buscam promover a imagem da companhia elencando ações que reafirmem sua responsabilidade social. No entanto, se as medidas tomadas forem voltadas para a proteção da imagem já estabelecida pela instituição, de forma que as narrativas incorram em negação ou justificativas de alguma acusação, ocorre então um gerenciamento de impressão protecionista. Um exemplo é o emprego de elementos gramaticais menos complexos quando os relatórios tratam de desempenho financeiro positivo (BHANA, 2009).

Diversos estudos têm sido realizados sobre essa temática, sendo os primeiros na área da psicologia clínica. A pesquisa de Braginsky e Braginsky (1967), por exemplo, examinou se pacientes com esquizofrenia crônica poderiam tentar manipular estratégias de gerenciamento 
de impressão em entrevistas. Os autores verificaram que os pacientes apresentavam-se como "sadios" ou "doentes" conforme suas necessidades e objetivos, sendo capazes de empregar estratégias de gerenciamento.

Destaca-se também o trabalho de Leary e Kowalski (1990), que apresentaram um modelo de dois componentes no qual a literatura sobre gerenciamento de impressão está baseada. Os autores apontaram dois processos que compõe esse assunto, onde o primeiro envolve as motivações do gerenciamento de impressão. Esse processo é composto de três fatores: a relevância da impressão que é criada, o valor do que se deseja obter ao criar essa impressão e a discrepância entre a imagem passada e a realidade. $O$ segundo processo diz respeito à construção da impressão. Foram delimitados cinco fatores que determinam que tipo de impressão os indivíduos tentam construir: auto-conceito, imagem de identidade desejada e indesejada, limitação dos papéis, relevância dos objetivos e a atual imagem social.

Frink e Ferris (1998) investigaram os efeitos da prestação de contas no estabelecimento de metas num contexto de avaliação de desempenho. Os autores realizaram dois testes para verificar o estabelecimento de tarefas e definição de alvos com dois grupos diferentes: estudantes universitários e funcionários de telemarketing. Os resultados indicaram que os participantes organizam tarefas e estabelecem metas de forma diferente de acordo com as condições para prestação de contas. Além disso, as diferenças encontradas entre os objetivos e desempenhos refletem o emprego de gerenciamento de impressão para níveis maiores de prestação de contas.

Osma, Guillamón-Saorín e Arts (2010) examinaram a relação entre o gerenciamento de resultados e gerenciamento de impressões nas demonstrações contábeis auditadas e relatórios da administração de uma amostra de companhias espanholas no período de 2005 a 2006. Os autores verificaram que as companhias que empregaram técnicas de gerenciamento de resultado nas demonstrações também utilizam algum tipo de gerenciamento de impressão nos relatórios. Ou seja, ambas técnicas são complementares quando existe um interesse self-serving dos gestores e são utilizadas em diferentes níveis de comunicação.

Wills (2008) realizou pesquisa na área e investigou duas formas particulares de gerenciamento de impressão comumente encontradas nos relatórios corporativos anuais: a distorção de narrativas e manipulação de gráficos. Foi realizado um experimento no qual os 
participantes recebiam informações de duas empresas fictícias, no qual uma delas apresentava gerenciamento e era requerido que realizassem decisões de investimentos. Os autores verificaram que não havia diferença significativa entre as decisões dos participantes, concluindo que o gerenciamento de impressões não afeta a percepção do desempenho da empresa.

No Brasil, Mendonça et al (1999) começaram analisando como o gerenciamento de impressões, a comunicação e ações simbólicas podem facilitar o processo de mudança organizacional através da descrição do processo de mudança empreendido por uma agência de comunicação. Os autores perceberam que o gerenciamento de impressões constitui-se de uma importante ferramenta na mudança organizacional.

Souza, Nascimento e Bernardes (2013) discutiram o malefício que o fenômeno da contabilidade criativa causa à essência da Ciência Contábil. Diante disso, o estudo foi realizado com base no método dedutivo e desenvolvido por meio de uma pesquisa exploratória, através de procedimentos bibliográficos. Diante dos resultados da pesquisa, os autores concluíram que o fenômeno contabilidade criativa é um mal indesejado - porém existente - para a ciência contábil e sua prática, pois fere princípios e convenções contábeis, descaracteriza as Demonstrações Contábeis das entidades, induzindo seus usuários a erros de avaliação da real situação e performance patrimonial da empresa, além de eticamente inapropriada para os profissionais contábeis.

Já o trabalho conduzido por Sousa (2013) abordou o gerenciamento de impressão nas mensagens dos diretores-presidentes publicadas nos relatórios anuais. Para o estudo, foram recuperados 120 relatórios anuais de empresas que negociaram suas ações na BM\&FBOVESPA referentes ao ano de 2011, onde se analisou apenas a mensagem da presidência. $\mathrm{O}$ autor verificou que as empresas divulgam mais informações positivas sobre seus resultados do que informações negativas. Porém, não foi possível confirmar a hipótese levantada de que o gerenciamento de impressão está negativamente relacionado à força da governança corporativa. 


\subsection{Relatório da Administração e a Utilização de Recursos Gráficos}

\subsubsection{Relatório da Administração}

Segundo a Lei 6.404/1976, Lei das Sociedades Anônimas, o Relatório da Administração é uma peça integrante do conjunto de informações que as empresas de capital aberto colocam à disposição do público em geral, juntamente com as demonstrações contábeis, acompanhadas pelas Notas Explicativas e Relatório dos Auditores Independentes Sobre as Demonstrações Contábeis. O artigo 133 da referida lei menciona que as companhias abertas deverão divulgar relatório da administração sobre os negócios sociais e os principais fatos administrativos do exercício findo, sendo possível elencar ainda o que deverá ser reportado por tal documento:

a) Aquisição de debêntures de sua própria emissão (art. $55, \S 3^{\circ}$ );

b) Fatos relevantes ocorridos durante o exercício, relativos à execução das obrigações assumidas pela companhia, aos bens garantidores das debêntures e à constituição e aplicação do fundo de amortização, se houver. Constará ainda declaração do agente sobre sua aptidão para continuar no exercício da função $\left(\operatorname{art} .68, \S 1^{\circ}\right)$.

c) Política de reinvestimento de lucros e distribuição de dividendos constantes de acordo de acionistas (art. $\left.118, \S 5^{\circ}\right)$;

d) A participação recíproca, quando ocorrer em virtude de incorporação, fusão ou cisão, ou da aquisição, pela companhia, do controle de sociedade, deverá ser mencionada nos relatórios (art. 244, § 5 $)$;

e) Negócios sociais e principais fatos administrativos ocorridos no exercício (art. 133, inciso I);

f) d) relação dos investimentos em sociedades coligadas e/ou controladas evidenciando as modificações ocorridas durante o exercício (art. 243).

Apesar de a Lei exigir a apresentação do RA, é a Comissão de Valores Mobiliários (CVM) que orienta a divulgação deles por parte das companhias de capital aberto no Brasil. Através do Parecer de Orientação $n^{\circ} 15 / 87$, a CVM recomendou às companhias abertas a divulgação de alguns itens como forma de melhorar a qualidade das informações apresentadas pelos gestores aos usuários externos:
a) Descrição dos negócios, produtos e serviços
b) Comentário sobre a conjuntura econômica geral
c) Recursos Humanos
d) Pesquisa e Desenvolvimento 

e) Investimentos
f) Novos produtos e serviços
g) Proteção ao meio ambiente
h) Reformulações administrativas
i) Investimentos em controladas e coligadas
j) Direitos dos acionistas e dados do mercado
k) Perspectivas e planos para o exercício em curso e os futuros
1) Empresas investidoras

Diante da abordagem dada pela legislação aos RAs, Dias Filho e Nakagawa (2001) afirmam que tão "importante quanto garantir a informação certa é garantir que ela se torne compreensível ao usuário, para que ele possa utilizá-la como instrumento de apoio ao processo decisório". Dessa forma, é possível perceber a importância dos RAs no processo de comunicação contábil e como além de suportarem esse processo fornecendo dados e informações adicionais, também acabam atendendo a um maior número de usuários por serem menos técnicos que as demais demonstrações contábeis (SILVA; RODRIGUES, 2006).

O mesmo foi observado por Doná et al (2016) que apontaram que os RAs contemplam informações sobre o desempenho financeiro das empresas de tal forma que os gestores comunicam-se com o público externo, sem a necessidade de um rigor técnico maior. Assim, por conta da sua natureza analítica e linguagem utilizada, as informações divulgadas no RA atingem um maior número de usuários. Em resumo, os relatórios anuais constituem um meio em que a gerência pode comunicar seus resultados às partes interessadas sem que sua publicação seja obrigatória (SOUZA, 2013).

No entanto, apesar da importância dos RAs para tomada de decisão, Rowbottow e Lymer (2010) afirmam que analistas têm considerado os relatórios da administração uma ferramenta de relações públicas, no qual os gestores podem providenciar uma imagem enviesada de sua performance, e por isso têm buscado outros canais mais independentes de informações não financeiras, já que o conteúdo do RA pode estar disposto de forma a ofuscar ou salientar determinadas informações segundo o interesse da administração.

Li (2008) observou que as pesquisas realizadas com enfoque nos relatórios da administração geralmente possuem duas abordagens distintas. Enquanto algumas pesquisas buscam identificar o nível de disclosure voluntário, outras analisam o nível da facilidade de 
leitura e compreensão em tais documentos. $\mathrm{O}$ autor aponta possíveis fatores que influenciariam a forma como os relatórios são escritos, estando eles relacionados ao desempenho financeiro atual e ao desempenho futuro das empresas.

Os gestores são incentivados a ofuscar informações quando o desempenho financeiro da empresa é negativo, porque a informação que é mais difícil de compreender também é refletida com menos impacto nos preços de mercado. Nesse sentido, os textos dos relatórios anuais são mais complexos com o objetivo de postergar a compreensão de algumas informações. Por outro lado, empresas com perspectiva de melhor desempenho futuro tendem a evidenciar as informações de maneira mais transparente para diminuir o custo informacional e para sinalizar ao mercado que seus resultados são persistentes.

Ainda sobre as perspectivas aplicadas às pesquisas que abordam os relatórios da administração, Stanton e Stanton (2001) revisaram a literatura existente sobre o assunto e identificaram cinco óticas que norteiam esses estudos: economia política, legitimidade organizacional, accountability, mercado e comunicação. Por exemplo, quando um RA é escrito de forma a reduzir os efeitos desfavoráveis da imagem corporativa, ou como um documento proativo que esteja direcionado para atender a objetivos específicos dos gestores, é possível observar motivações explicadas pela legitimidade organizacional e também pelo mercado. Os autores afirmam que esses diferentes pontos de vistas podem ser usados para explicar como um enfoque no formato, no disclosure voluntário ou nos elementos narrativos dos RAs podem ser prejudiciais para o papel deles de documento contábil tradicional.

Dagiliene (2015) analisou o conteúdo dos relatórios anuais publicados em 2007 e 2008 por quatro companhias lituanas, usando como métrica as frases sobre responsabilidade social e quantidade de páginas dos relatórios. Os resultados da pesquisa indicaram que o conteúdo dos relatórios não são facilmente compreendidos e que as empresas analisadas utilizam elementos narrativos para reportar informações relativas à responsabilidade social (corporate social responsability - CSR), mas nenhum elemento quantitativo. Nenhuma das empresas divulgou informações a respeito de atividades na comunidade e somente uma delas reportou atividades voltadas para conservação ambiental.

Outra pesquisa na área foi realizada por Rowbottow e Lymer (2010). Estes autores exploraram a utilização e os usuários das narrativas contábeis dos relatórios anuais publicados 
em plataformas virtuais pelas maiores companhias listadas no mercado de capitais londrino. Os resultados sugeriram que aqueles usuários com maior experiência em analisar e preparar demonstrações financeiras adotaram diferentes preferências informacionais no que diz respeito aos relatórios anuais disponíveis de forma virtual.

Jones e Slack (2009), por sua vez, examinaram os objetivos relativos ao compromisso ambiental reportados nos relatórios anuais de 20 companhias do Reino Unido durante os anos de 2004 e 2008. Os autores verificaram uma utilização diferente dos objetivos reportados nos relatórios por aquelas companhias inseridas em setores de maior impacto ambiental. Isso significa que as empresas utilizam os relatórios anuais para gerenciarem sua imagem perante o público. Foi percebido ainda que as empresas classificadas como de impacto maior também reportavam informações mais detalhadas e com viés negativo. Para os autores, esse também é um sinal de gerenciamento no que diz respeito à utilização do disclosure ambiental para reforçar perante os usuários da informação o compromisso empresarial com o meio-ambiente.

Li (2008) também investigou o conteúdo dos RAs, examinando a relação entre a legibilidade dos relatórios anuais, desempenho financeiro das empresas e continuidade dos lucros de companhias públicas. A legibilidade foi medida usando o índice $F o g$ e a extensão dos documentos. O autor verificou que os relatórios anuais de empresas com desempenhos inferiores são mais difíceis de serem lidos (os índices Fog são mais altos ou os relatórios são mais extensos) e empresas que divulgaram relatórios mais fáceis de serem lidos apresentam menos flutuação de resultados.

Já no Brasil, Dalmácio e Paulo (2004) realizaram uma pesquisa a fim de verificar qual a forma mais eficiente de evidenciação da informação contábil, que poderia facilitar a compreensão e a interpretação de aspectos socioambientais e econômico-financeiros para os usuários, através da análise das demonstrações contábeis de empresas industriais do estado do Espírito Santo. Os autores encontraram como resultado que a evidenciação das informações propostas oscilava entre os RAs e as notas explicativas, sendo que os RAs, como forma de evidenciação, mostram-se ser mais flexíveis e interessantes para os usuários externos.

Em sua tese, Rodrigues (2012) buscou identificar quais os fatores determinantes que influenciaram a evolução das informações divulgadas nos Relatórios da Administração das companhias abertas brasileiras do período de 1997 a 2010. Para isso, a autora analisou os RAs 
de 130 empresas (utilizando-se de três técnicas de investigação: análise de conteúdo, análise do formato e análise da legibilidade). Entre os resultados, verificou-se que, com o passar dos anos, em média, as empresas vêm aumentando o volume de informações (letras e palavras) e de gráficos e tabelas divulgados nos Relatórios da Administração e que os assuntos mais divulgados nos RAs foram Reforma da Administração e Descrição de Negócios.

Doná et al (2016) analisaram os fatores determinantes do conteúdo divulgado no Relatório da Administração de companhias com ações negociadas na BM\&FBOVESPA, do setor consumo cíclico, subsetor comércio, no período de 2008 a 2013. Os fatores analisados foram porte, participação acionária, segmento de governança, retorno sobre o patrimônio líquido e retorno sobre o ativo. Os resultados indicaram relação positiva e significante entre o volume de informações contido nos Relatórios da Administração e o porte, o segmento de governança e a rentabilidade das empresas. Já para o caso da participação acionária, não foi identificada relação estatisticamente significante.

\subsubsection{Utilização de Recursos Gráficos nos Relatórios da Administração}

Num ambiente econômico altamente competitivo, é de se esperar que as empresas busquem divulgar seus informes financeiros em um formato mais globalizado, ou seja, que permita e assegure a comunicação das informações financeiras tornando-as úteis para captar recursos e investimentos estrangeiros. Assim, as companhias devem providenciar relatórios anuais acessíveis para os demais países e isso inclui a utilização de recursos universalmente compreensíveis, como o emprego de gráficos e demais recursos visuais.

Segundo Rodrigues e Silva (2006), essas ferramentas têm a capacidade de contar uma história de forma interessante e atrativa, permitindo a compreensão rápida de fenômenos que dificilmente seriam percebidos de outra forma. Então, para aprimorar a comunicação contábil através dos Relatórios da Administração, os gestores utilizam recursos gráficos que sintetizam as informações e ainda atraem a atenção do leitor, bem como facilitam a memorização das informações reportadas através deles (HUANG et al, 2008).

Beattie e Jones (2008) alegam que existem quatro grandes benefícios decorrentes da utilização de recursos gráficos nos relatórios anuais. Primeiramente, os gráficos empregam diferentes cores que estimulam os sentidos visuais e captam a atenção. Eles também são mais 
diretos e transmitem as informações pretendidas mais facilmente. Em terceiro, eles permitem que a informação seja localizada e reunida de maneira mais rápida e por fim, as informações são demonstradas e expressas de maneira mais eficaz.

Uyar (2008) também descreveu algumas razões que motivam o emprego dos gráficos nos relatórios anuais e afirma que a evidenciação voluntária desses recursos têm crescido nos informes publicados por grandes companhias devido às vantagens proporcionadas por eles. Entre elas está o fato de serem absorvidos mais facilmente e proporcionarem maior velocidade ao processo de tomada de decisão. Também são mais fáceis de serem lembrados do que as tabelas, permitem comparações, simplificam dados quantitativos mais complexos, e demonstram a relação entre as variáveis reportadas.

No entanto, nem sempre os gráficos são empregados unicamente com o objetivo de reportar a informação contida nele. Huff (1954) afirma que, quando os números dispostos em tabelas ou as palavras usadas para explicá-las não são suficientes para vender uma ideia, chocar, convencer ou conduzir o leitor a fazer algo, então utiliza-se o recurso visual estatístico mais simples: os gráficos. Gráficos são recursos visuais que expressam e resumem informações quantitativas e as relações existentes entre elas (KOSSLYN, 1989), e segundo Beattie e Jones (2008a) são usados para duas finalidades principais: explorar/analisar dados e apresentar/comunicar informações a um público específico.

Assim, os gráficos contidos nos relatórios da administração são utilizados para apresentar e comunicar dados financeiros, e a partir daí pode-se apontar que os tipos de gráficos empregados para isso dependem justamente da identificação dessa finalidade. Gráficos de barra e coluna, por exemplo, são mais apropriados para apresentar dados de evolução cronológica, já gráficos setoriais são mais utilizados para reportar dados qualitativos e as posições das categorias de uma mesma variável (AECA,2012).

Nesse sentido, Beattie e Jones (1992) conseguiram verificar que os principais tipos de gráficos empregados em relatórios financeiros eram de coluna, linha, barra e pizza, mas que mais de 50\% das vezes, o gráfico mais utilizado para reportar informações financeiras era o de coluna. Também é possível destacar quais os principais conteúdos reportados através desses recursos. Steinbart (1989), Beattie e Jones (1992) e Mather et al (2000) identificaram um conjunto de três variáveis financeiras-chave (key financial variables - KFV/VFC) que 
apareciam com maior frequência sendo reportadas através de recursos gráficos, sendo elas: lucro líquido, receita líquida e dividendos, que passaram a ser consideradas na investigação de pesquisas da área voltadas para a análise de seletividade.

Esses achados estão inseridos em estudos que analisaram a possibilidade de manipulação das narrativas contábeis por meio da utilização de gráficos. Wills (2008) destaca que as pesquisas anteriores têm apontado quatro tipos principais de infidelidades gráficas nos relatórios da administração: seletividade, reforço da apresentação, distorções de orientação e distorções de medidas, sendo esses dois últimos complementares.

A seletividade envolve a escolha de utilizar ou não gráficos, quais variáveis empregar neles e que períodos cobrir. Goundar (2009) afirma que a seletividade gráfica diz respeito às escolhas sistemáticas da administração quanto a incluir ou excluir gráficos baseada na relação do gestor com o desempenho financeiro da companhia. Beattie e Jones (1992) apontou a escolha deliberada de inclusão de gráficos que reportam variáveis financeiras-chaves (VFC) nos relatórios anuais. Outro cenário de seletividade é a inclusão de gráficos em relatórios de companhias que apresentaram aumento em seus ganhos, hipótese suportada pelo estudo de Mather et al (2000) que verificaram maior incidência de gráficos nos relatórios de companhias com lucros crescentes. Mais um exemplo possível é o caso da instituição, que decide deliberadamente utilizar gráficos para cobrir apenas o período referente ao desempenho financeiro positivo e crescente, de tal forma que este recurso represente uma perspectiva de crescimento e encubra possíveis quedas de resultado.

A melhora da apresentação envolve as escolhas de estratégias de design dos gráficos para manipular os dados, como formato e plano de fundo, de tal forma que notícias desfavoráveis sejam camufladas. Ferreira (2015) explica que a melhora da apresentação acontece sempre que um ou mais elementos de um gráfico impedem a correta compreensão dos dados dispostos. A distorção vem de recursos como elementos em três dimensões, ausência de títulos, cores cuja intensidade esteja associada a valores numéricos, linhas desnecessárias, entre outras coisas, que violam alguns dos princípios básicos de construção gráfica apontados por Kosslyn (1989), como a obrigatoriedade de se colocar todas as variáveis, títulos e informações para evitar ambiguidades e o cuidado de evitar cores para destacar informações selecionadas intencionalmente. 
Já a distorção por orientação envolve a alteração do parâmetro de angulação, feita através de mudanças tanto na altura quanto na largura da linha de tendência dos gráficos. Cleveland e McGill (1986) verificaram que, quando parâmetros de inclinação divergem de 45, os dados são ineficazes e provocam julgamentos imprecisos e enviesados.

E por fim, as distorções de medidas, que são as mais encontradas nos gráficos, ocorrem quando existe representação física de números nos gráficos que não são diretamente proporcionais aos números destacados (BEATTIE; JONES, 2002). Essa infidelidade viola princípios de construção gráfica apontados por Tufte (1983) que afirmou que as unidades físicas devem ser diretamente proporcionais aos números representados, assim como as dimensões adotadas não devem exceder as dimensões dos dados.

É possível verificar esse tipo de distorção no exemplo proposto por Penteado (2013), no qual um gráfico de coluna ilustra a evolução no número de funcionários de uma empresa no período de três anos. Se as proporções estivessem corretas, a coluna do último período deveria ser três vezes maior do que a coluna do primeiro, mas com a apresentação seis vezes maior, o gráfico sugere um crescimento visualmente maior que o apresentado realmente.

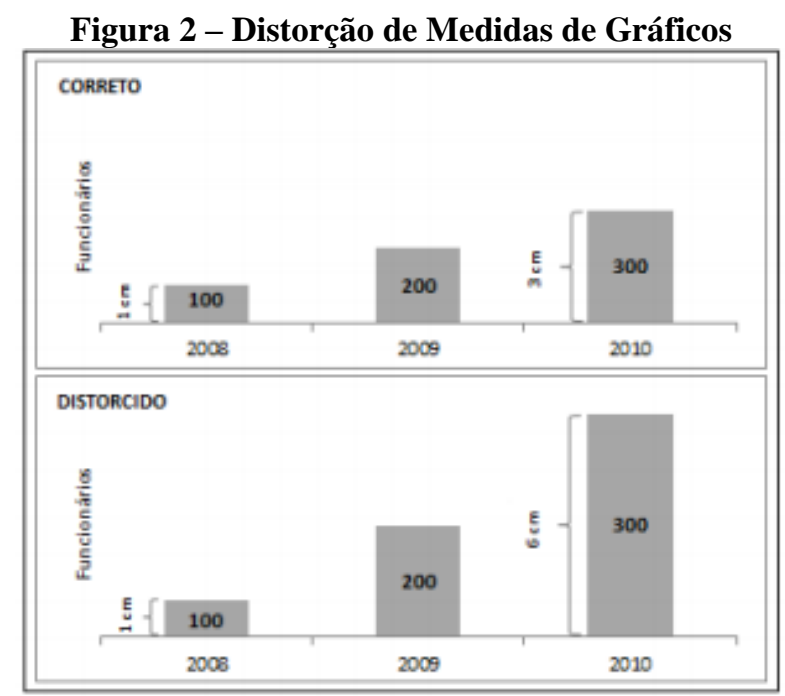

Fonte: PENTEADO, 2013.

Beattie e Jones (2008a) relatam que todos os estudos realizados com a finalidade de avaliar esse aspecto do gerenciamento de impressão fizeram uso do Índice de Discrepância Gráfica (graphical distortion index - GDI), que é uma variação do "fator de mentira" de Tufte (1983) proposto por Taylor e Anderson (1986) e compara a variação das informações numéricas 
e a variação das medidas físicas dos gráficos. Como resultado, um índice de $0 \%$ indica que o gráfico foi corretamente construído.

Caso o GDI seja maior que 5\% e menor que $-5 \%$, então há indicação de que os gráficos estão distorcidos e ocorreu gerenciamento de impressão. O GDI pode ser calculado através da fórmula dada por: Índice de Discrepância Gráfica $(G D I)=[(a / b)-1] x 100$, onde, " $a$ " corresponde ao percentual de Mudança Física de Gráficos Construídos Incorretamente e " $b$ " é o Percentual de Mudança Física Correta, obtidos através dos seguintes cálculos:

$\mathbf{a}=[($ medida física do último período - medida física do primeiro período $) /$ medida física do

$$
\text { primeiro período] x } 100 \quad \mathrm{e}
$$

$\mathbf{b}=[($ medida física correta do último período - medida física do primeiro período $) /$ medida

física do primeiro período] x 100

Beattie e Jones (1992) condensam esses itens de infidelidade gráfica em apenas três: seletividade, melhora da apresentação e distorção de medidas e classifica o primeiro como escolha gráfica primária e os outros dois como escolhas gráficas secundárias. Eles afirmam que todas as três formas de manipulação podem ser resultados tanto da falta de competência do preparador das informações como de manipulação deliberada. No Quadro 1, é possível observar um resumo das principais evidências de distorção gráfica classificadas conforme o tipo de distorção:

Quadro 1: Tipos e Causas de Distorções Gráficas

\begin{tabular}{|c|l|}
\hline Tipo de Distorção & \multicolumn{1}{c|}{ Causa da Distorção } \\
\hline \multirow{3}{*}{ SELETIVIDADE } & 1. Exagero na tendência de dados favoráveis; \\
& 2. Subestimação de tendências negativas dos dados; \\
& 3. Maior propensão para apresentar variáveis-chave em \\
empresas com bom desempenho;
\end{tabular}

Fonte: AECA (2012). 
Diante desses itens, a comunicação contábil incorre no risco de ser prejudicada porque os preparadores dos Relatórios da Administração podem manipular a apresentação dos recursos gráficos de forma a beneficiar os interesses da gestão. Beattie e Jones (2002) verificaram isso em pesquisa experimental onde foram avaliados se níveis de distorção conhecidos influenciavam a percepção dos usuários quanto ao desempenho financeiro da empresa. Os autores concluíram que usuários com níveis menores de conhecimentos financeiros têm maior probabilidade de serem enganados por gráficos distorcidos.

No entanto, apesar de evidências e práticas definidas de manipulação gráfica encontradas na literatura, Beattie e Jones (2008) afirmam que a matéria ainda carece de uma teoria que suporte as motivações dos gestores. O paradigma que mais se aproxima e tem sido utilizado para embasar as pesquisas é o gerenciamento de impressão que basicamente sugere que os gestores tendem a apresentar-se sob uma ótica favorável, mas outras teorias ainda podem ser exploradas para explicar esse fenômeno nas narrativas contábeis, como a teoria da legitimidade e teoria institucional. Os autores também afirmam que existe uma carência de estudos sobre o assunto sobre os relatórios de companhias de países em desenvolvimento, que poderiam apontar preferências administrativas no que tange à evidenciação, bem como potenciais diferenças culturais.

Beattie e Jones (2008a) revisaram e sintetizaram a literatura existente até então sobre gráficos e evidenciação financeira, identificando qual o panorama teórico que suporta as pesquisas na área, as principais práticas de manipulação e distorções gráficas e quais consequências provocam no mundo corporativo. Os autores afirmam que apesar do crescente número de estudos na área, esse é um campo de pesquisa relativamente recente e que o primeiro estudo sistemático foi feito em 1980, por Johnson, Rice e Roemmich. No entanto, até o ano de 2006, os autores identificaram 20 estudos acadêmicos publicados sobre gráficos em relatórios financeiros realizados majoritariamente nos Estados Unidos e países europeus desenvolvidos com enfoque principalmente nos relatórios da administração. Apenas um trabalho investigou relatórios de instituições de caridade, um de entidades sem fins lucrativos e outro analisou prospectos de IPO (Initial Public Offering), sendo quatro deles estudos experimentais. A condução desse tipo de estudo permite que sejam investigados os impactos que gráficos distorcidos possuem sobre as percepções dos usuários. 
O primeiro estudo experimental realizado sobre as percepções dos usuários dos gráficos contidos nos relatórios anuais foi realizado por Taylor e Anderson (1986, apud BEATTIE; JONES, 2008a) O objetivo era testar o impacto das escolhas de formatos gráficos em usuários de dados financeiros. Foram enviados sete pares de gráficos para gerentes de empréstimos comerciais de bancos americanos. Em cada par, um deles violava algum princípio de construção gráfica. Os autores não utilizaram nenhum teste estatístico para mensurar os resultados mas concluíram que as percepções sobre os gráficos construídos indevidamente eram notavelmente diferentes.

Beattie e Jones (2002) publicaram o primeiro trabalho a abordar um experimento comportamental para investigar a magnitude dos efeitos gráficos na percepção do desempenho corporativo. O objetivo foi investigar os parâmetros de inclinação dos gráficos no contexto da evidenciação financeira. Foram apresentados a 52 estudantes, seis pares de gráficos sem escala e sem valores para evitar qualquer processamento cognitivo, durante 3 segundos, e era requerido que os participantes identificassem o gráfico que melhor representava uma situação apresentada, sendo um deles fisicamente distorcido. Percebeu-se que distorções de 5\% não possuíam efeito significante, enquanto distorções de $10 \%$ e acima possuíam impacto significante ao nível de 5\%. Também constatou-se que participantes com melhor nível de conhecimento financeiro estavam mais propensos a interpretarem dados incorretamente quando auxiliados por gráficos distorcidos.

Huang et al (2008) objetivaram discutir se informações financeiras divulgadas por meio de tabelas, gráficos distorcidos e não distorcidos possuem alguma influência sobre os julgamentos e decisões dos investidores em Taiwan. Os autores realizaram experimento onde foram testados os efeitos no julgamento de investidores ao compararem diferentes tipos de exposição de informações financeiras. Verificaram que participantes que haviam recebido informações através de gráficos tomaram decisões mais acertadas, no entanto, esses usuários não foram capazes de identificar distorções entre os gráficos apresentados.

Burgees et al (2008) investigaram se Contadores Americanos (certified public accountants - CPAs) e demais usuários de relatórios financeiros acreditam que gráficos distorcidos podem influenciar julgamentos e se há a necessidade de regulação governamental quanto ao assunto. Foram aplicados questionários a 160 respondentes, incluindo contadores certificados e estudantes de pós graduação em diferentes programas e estágios do curso, 
indagando o nível de concordância deles com as afirmações propostas. Os resultados mostraram que os profissionais estão cientes da potencial influência da distorção gráfica, acreditam que existe necessidade de regulação para a construção de informações gráficas nos relatórios anuais e concordam que os auditores deveriam atestar a adequação desses gráficos

Willians e Martin (2015) propuseram um experimento comportamental para investigar em que nível gráficos distorcidos fisicamente podem influenciar os julgamentos e predições dos usuários, bem como se há influência de informações omitidas nos gráficos sobre a percepção do leitor e se existe relação entre as percepções obtidas e o gênero dos usuários. Foram apresentados seis gráficos com dados sobre a receita semanal do primeiro trimestre do ano a 157 estudantes de pós graduação, sendo 86 homens e 71 mulheres. Foi requerido que com base nas informações fornecidas, os participantes apontassem um valor provável de receita para a primeira semana do trimestre seguinte. Os resultados foram obtidos a partir da análise de cada gráfico, e percebeu-se que para determinadas distorções e omissão de informações, o julgamento preditivo é afetado por elas. Também constatou-se que quando informados por meio gráficos distorcidos, homens tendem a fazer predições com valores significativamente mais elevados que os valores de referência que as mulheres.

No Brasil, também foram realizadas pesquisas de abordagem experimental. O primeiro trabalho identificado foi publicado por Pereira et al (2004) que procurou comparar o nível de percepção dos usuários da informação contábil em Florianópolis (SC) e Recife (PE) sobre a utilidade das representações gráficas no processo de evidenciação. Foram aplicados questionários a 41 participantes atuantes nos mais diversos ramos, onde apresentou-se um Balanço Patrimonial e uma Demonstração de Resultados fictícia e, ao lado, as mesmas informações apresentadas na forma de gráficos de coluna com efeito visual 3-D. Nas duas capitais, a maior parte dos entrevistados considerou que a representação gráfica melhora muito a compreensão das informações contábeis, principalmente no que concerne à facilidade de visualização das variações de valores.

Silva e Lima (2007) analisaram se a forma como as demonstrações contábeis e relatórios são apresentados pode influenciar a percepção e decisão dos usuários de informações financeiras. Os autores aplicaram 1.850 questionários entre discentes dos cursos de ciências contábeis e administração, compostos de cinco experimentos, onde os experimentos 3 e 4 buscaram verificar se a utilização de recursos textuais e/ou gráficos pode alterar a percepção e, 
consequentemente, a decisão dos indivíduos. Os resultados indicaram que o efeito da formatação dos gráficos e como as informações são divulgadas no Relatório da Administração provocam impacto sob a decisão do usuário, especialmente no que diz respeito à avaliação de risco, que pode ser amenizada simplesmente pela manipulação de recursos gráficos.

E Souto-Maior et al (2012) buscaram contribuir com a literatura sobre o assunto através de uma experiência de decisão de investimento entre duas empresas fictícias. Foram aplicados 267 questionários a estudantes da UFSC, nos quais eles deveriam escolher quanto investir em cada uma das alternativas de investimento (empresa A e empresa B). Os resultados mostram que a média de investimento na empresa A se alterou de forma significativa ao nível de $1 \%$. Porém, diferentemente do esperado, em ambos os casos a distorção aumentou a porcentagem de investimento na empresa $\mathrm{A}$, mesmo quando os gráficos da empresa $\mathrm{B}$ eram distorcidos para apresentarem uma tendência mais positiva.

\subsection{Pesquisas Empíricas Anteriores: Relação entre a utilização de gráficos e o desempenho financeiro}

As principais pesquisas empíricas na área têm se ocupado de investigar a relação entre o emprego de gráficos e o desempenho financeiro das empresas. Essa investigação tem conduzido os autores a resultados indicativos de gerenciamento de impressão na forma de seletividade gráfica, melhora ou realce de apresentação e também distorções gráficas que, na sua maioria estão positivamente relacionados aos "bons resultados" das companhias.

O primeiro trabalho acadêmico sobre a utilização de recursos gráficos em Relatórios da Administração foi publicado por Steinbart (1989). O autor tentou determinar se os gráficos presentes nos relatórios anuais de 319 companhias americanas no ano de 1986 foram empregados de modo a criar uma impressão mais favorável do desempenho da empresa. Para isso, foram conduzidos testes estatísticos que verificaram que companhias que apresentaram crescimento nas receitas líquidas usam mais gráficos sobre variáveis financeiras-chave e que $26 \%$ dos gráficos relativos a vendas, lucros e dividendos apresentaram distorção física igual ou maior que $10 \%$ e que a frequência de dados distorcidos é maior em relatórios de empresas que apresentaram piora nos resultados. 
Beattie e Jones (1992), autores mais profícuos na área, investigaram o uso e abuso de gráficos em relatórios financeiros e analisaram os relatórios anuais das 240 maiores empresas do Reino Unido no ano de 1989, documentando a natureza e extensão do uso de gráficos. Identificaram indícios de seletividade nos relatórios analisados, onde $65 \%$ das companhias utilizaram pelo menos um gráfico relativo a variáveis financeiras-chave. Também verificaram que companhias com melhor desempenho financeiro empregam mais gráficos, e que $30 \%$ deles apresentavam distorções gráficas.

Em 1994, Beattie e Jones investigaram pela primeira vez, as escolhas de formato envolvendo gráficos de relatórios anuais de entidades de caridade, seu compromisso com os princípios de construção gráfica e se há evidências de que os gráficos são empregados para transmitir informações de desempenho de maneira mais favorável à entidade. Foram analisados 76 documentos provenientes das 50 maiores instituições de caridade do Reino Unido, com utilização do GDI e dois outros índices de distorção desenvolvidos pelos autores, bem como análise de seletividade através da identificação de gráficos referentes a variáveis financeiraschave. Os resultados indicaram que mais de $70 \%$ dos gráficos analisados reportavam informações relativas às receitas das entidades e que 54\% dos gráficos de variáveis financeiras eram no formato de pizza, considerado apropriado para evidenciar proporções.

Mather et al (1996) testaram hipóteses concernentes à relação entre o uso e construção de gráficos em relatórios anuais e o desempenho financeiro de companhias australianas, averiguando indícios de seletividade e distorção de medidas gráficas. Foram analisados os relatórios anuais dos anos 1991 e 1992 das 143 maiores companhias australianas e das 44 maiores entidades sem fim lucrativos do país, através de coleta de dados relativos à quantidade de gráficos, emprego de variáveis financeiras chaves (KFV) e distorções de medidas gráficas com utilização do GDI. Para a amostra total não foi encontrada relação significante entre as variáveis analisadas e o desempenho das companhias, diferentemente dos resultados encontrados nos Estados Unidos e Reino Unido. No entanto, foi possível perceber que companhias menores são mais propensas a empregar gráficos de variáveis financeiras chaves em seus relatórios quando há melhora no desempenho.

Beattie e Jones (1997) se propuseram a comparar as práticas de evidenciação gráfica de companhias americanas e inglesas. Foram analisados os relatórios anuais de 176 empresas dos EUA e Reino Unido no ano de 1990, nos quais verificou-se que nos dois países, são utilizados 
pelo menos um gráfico referente a uma das variáveis financeiras-chave associadas ao crescimento do resultado ao nível de significância de $5 \%$.

Mather et al (2000) foram os primeiros autores a analisar a utilização de gráficos em outra fonte que não fossem os relatórios anuais. Procuraram investigar a utilização, seleção de variáveis, e construção de gráficos existentes em prospectos de IPO de empresas australianas. Foram levantadas todas informações gráficas de 484 prospectos de IPO de empresas australianas no período de 1991 a 1993, com utilização de testes estatísticos e uso do GDI. Constatou-se que aproximadamente $57 \%$ dos gráficos analisados apresentavam distorções médias. Além disso, verificaram-se sinais de seletividade com a utilização de mais gráficos em relatórios de empresas com lucros crescentes, porém não foi encontrada evidência de associação significativa entre gráficos com distorções de medidas e o desempenho financeiro.

Beattie e Jones (2000a) examinaram se os gráficos com informações de variáveis financeiras-chaves são mais prováveis de serem incluídos quando o desempenho melhorou e se a distorção de medidas desses mesmos gráficos trazem uma percepção mais favorável da imagem das companhias. Os autores analisaram os gráficos dos relatórios de 300 companhias australianas, francesas, alemãs, inglesas e americanas. Foram encontradas evidências de seletividade, especialmente para gráficos sobre resultados e também distorções de medidas. No entanto, não foi possível explicar as diferenças de evidenciação entre os países, apesar dos resultados demonstrarem que países com mercado de capitais mais fortes apresentaram maior nível de gerenciamento de impressão.

Beattie e Jones (2000b) realizaram o primeiro estudo do tipo sob uma série temporal. A proposta desse trabalho foi determinar se o uso de gráficos depende do desempenho financeiro, através de uma hipótese de seletividade que estava focada na associação do desempenho e nas mudanças na utilização de gráficos. A análise foi feita nos relatórios anuais das 137 maiores companhias do Reino Unido que continuavam em atividade durante um período de cinco anos compreendido entre 1988 e 1992 . Foram encontradas evidências de associação entre o emprego de gráficos reportando conteúdos financeiros e o desempenho financeiro positivo das companhias.

Uyar (2011) Procurou investigar a associação entre as características da empresa e o nível de evidenciação voluntária de gráficos nos relatórios anuais de empresas turcas listadas 
no mercado acionário de Istambul (Stanbul Stock Exchang - ISE) no ano de 2006. Foi realizada análise de conteúdo dos relatórios anuais de companhias listadas no Índice ISE-100, onde levantou-se o tamanho da empresa de auditoria, a estrutura social, o desempenho financeiro e o tamanho das empresas. Os resultados indicaram que o tamanho da companhia e da empresa de auditoria tem associação significante positiva com a evidenciação voluntária de gráficos, enquanto desempenho financeiro e estrutura da sociedade não possuem associação significante.

Sartawi (2015) buscou descrever as práticas de evidenciação gráfica nos relatórios anuais de bancos jordanianos, através da investigação de distorções gráficas e fatores que influenciam o nível da utilização de gráficos. Foram coletados dados dos relatórios anuais de 15 bancos listados no Amman Stock Exchange no período de 2008 a 2013 e testadas hipóteses relativas à quantidade de gráficos. Foi constatada presença de distorções gráficas sinalizando a necessidade de maior regulação quanto a esse tipo de evidenciação e associação positiva entre a quantidade de gráficos e o desempenho financeiro da empresa.

Cho et al (2016) investigaram se empresas manipulavam os gráficos de seus relatórios de sustentabilidade com a finalidade de apresentar uma visão mais favorável do seu desempenho social e ambiental. O gerenciamento de impressão foi medido em 77 relatórios de empresas americanas no ano de 2006, pela presença de viés favorável na escolha dos itens reportados graficamente e pelos níveis de distorção medidos pelo Índice de Discrepância Gráfica Relativa (RGD). Também foi empregada análise de regressão múltipla para testar a relação entre o desempenho social e ambiental da empresa e os níveis de gerenciamento de impressão. Foi encontrada considerável evidência de seletividade na escolha dos conteúdos gráficos e moderada evidência de distorção gráfica. Gráficos de empresas que apresentaram desempenho social inferior empregaram maior nível de gerenciamento de impressão, enquanto não foi encontrada relação significante quanto aos níveis de desempenho ambiental.

No Brasil, ainda há uma escassez de estudos voltados para qualquer tipo de análise relacionada a recursos gráficos, sendo a maioria deles experimentais. O primeiro estudo empírico no Brasil foi realizado por Miranda et al (2008) que afirmam que após pesquisa bibliográfica nas principais revistas e base de dados brasileiras até o momento do trabalho, foram encontrados apenas dois trabalhos que abordavam o assunto, realizados por Pereira et al (2004) e Silva e Lima (2007). No entanto, ambos apresentavam abordagem distinta, sendo caracterizados pela aplicação de questionários a estudantes universitários quanto às percepções 
e efeitos no julgamento após a apresentação de informações gráficas conforme já apresentado na seção anterior.

Nesse contexto, o trabalho de Miranda et al (2008) tem como objetivo verificar se relatórios anuais que apresentam bom desempenho financeiro (lucro) utilizam gráficos de uma forma diferente dos que apresentam prejuízo. Foram analisados 37 relatórios de 17 empresas de capital aberto, com ações negociadas na bolsa de valores de São Paulo (IM\&FBovespa). Os relatórios foram obtidos nos sítios eletrônicos das respectivas empresas e investigou-se se há diferenças na quantidade de gráficos, na área destinada a representações gráficas e na natureza das variáveis representadas graficamente. Os resultados indicaram que relatórios de empresas com desempenho financeiro positivo apresentam mais gráficos, dedicam maior área a representações gráficas e apresentam gráficos com variáveis diferentes dos que apresentam prejuízo. Também foi possível constatar que relatórios que apresentam lucro menor que o do ano anterior tendem a apresentar gráficos adicionais para explicar as causas da redução do resultado.

Moreira et al (2011) verificaram a relação existente entre tamanho, lucratividade e alavancagem com o nível de evidenciação das informações financeiras de empresas do setor elétrico brasileiro para o ano de 2009. Foi feita análise por meio de teste de diferença de média e de regressão múltipla, tendo como variável dependente o nível de evidenciação, medido por meio da qualidade da informação (formato de apresentação: quantidade de gráficos, figuras e tabelas), e como variáveis explicativas o ativo total (LnAT), o retorno sobre o patrimônio líquido (RSPL) e a participação de capital de terceiros (PCT). Diferentemente do que as pesquisas internacionais realizadas anteriormente verificaram, os resultados não confirmam as hipóteses de pesquisa, já que mostraram que a lucratividade e o endividamento não são significativos e que o tamanho, apesar de significativo, tem relação negativa (quanto menor a empresa, menor o nível de evidenciação).

Penteado (2013) investigou se os gráficos apresentados nos relatórios de sustentabilidade de 50 empresas brasileiras de capital aberto foram utilizados para gerenciamento de resultados. Foram analisados os relatórios de sustentabilidade preparados de acordo com as diretrizes do Global Reporting Initiative no ano de 2011, buscando-se indícios de seletividade em relação às informações reportadas e distorções de medidas gráficas, com emprego do GDI. A autora concluiu que apesar de evidências de seletividade e distorções de 
medidas verificadas nos gráficos analisados, os resultados indicam com mais segurança um despreparo dos que elaboram a informação que alguma tentativa de gerenciamento de impressão.

Ao longo da execução deste estudo, também foram encontradas pesquisas relacionadas à utilização de recursos gráficos mas cujo o objetivo não estava voltado para análise da seletividade ou distorções gráficas através da relação existente entre utilização de gráficos e desempenho. Por exemplo, Muiño e Trombetta (2009) examinaram o impacto e qualidade (distorções) dos gráficos sobre o custo de capital, controlado pela interação entre o disclosure e as distorções gráficas. Foram coletadas informações gráficas dos relatórios anuais de 68 companhias listadas no mercado acionário de Madrid durante o período de 1996 a 2002. As proxies de gráficos foram colocadas como variáveis independentes e o custo de capital como variável dependente. Verificou-se que para níveis mais altos de evidenciação, a distorção gráfica aumenta o custo de capital e que a utilização de gráficos não tem impacto significante sobre as decisões dos usuários.

Goundar (2009) verificou se as empresas da Nova Zelândia usam gerenciamento de impressão para influenciar a apresentação do desempenho nos relatórios anuais de companhias que estão às voltas de uma troca de CEO. O autor examinou a utilização de gráficos nos relatórios, bem como as distorções gráficas existentes neles, através da presença de variáveis financeiras-chave e do GDI. Foram encontradas evidências de gerenciamento de impressão, mas gráficos não são tão comumente utilizados no país como evidenciado em outros estudos.

Rahman et al (2014) propuseram estabelecer a natureza e extensão do disclosure voluntário de informações gráficas nos relatórios anuais de 45 empresas púbicas listadas na Malásia. Através de análise de conteúdo, descreveu os tipos e tópicos de gráficos empregados nos relatórios anuais em um período de 30 anos, com intervalos de 10 anos (1974, 1984, 1994 e 2004). A maioria das empresas prefere usar gráficos de barra e houve um crescimento considerável da quantidade empregada ao longo do período.

Ferreira (2015) pretendia examinar o uso de gráficos em todas as companhias listadas no Euronext Lisboa em 2013. Para determinar os tipos de gráficos utilizados, foi realizada análise de conteúdo com auxílio de planilha excel e para determinar a distorção gráfica, fez-se 
uso do GDI. O autor percebeu o uso extensivo de gráficos, mas não identificou indícios de seletividade. Em contrapartida, verificou que haviam distorções de medida e orientação.

E no Brasil, Nascimento et al (2013) propôs como objetivo identificar o emprego de recursos visuais nos Relatórios da Administração das empresas brasileiras e analisar a influência dos gráficos na neutralidade das informações apresentadas. Os autores analisaram os relatórios de 203 empresas de vários setores, referentes ao período de 1997 a 2009. Identificaram a quantidade, tipos e características dos elementos visuais apresentados. Foi constatado que com o passar dos anos, houve um aumento do uso de recursos visuais (gráficos, tabelas, fotos). Também verificaram que o gráfico do tipo coluna foi o mais empregado e que uma parte desses diagramas pode dar margem a interpretações indevidas devido às técnicas empregadas em sua construção.

\subsection{Desenvolvimento das Hipóteses da Pesquisa}

Conforme apontado por Martins e Teóphilo (2009), as hipóteses são proposições que podem ser colocadas à prova para serem testadas ou ainda supostas explicações para o fenômeno que se investiga. A partir do que foi exposto no referencial teórico e pesquisas anteriores, são apresentadas a seguir as motivações norteadoras da formulação das hipóteses deste estudo.

\subsubsection{Hipóteses baseadas em seletividade}

Beattie e Jones (1992) afirmam que a seletividade, no seu nível mais fundamental, envolve em primeiro lugar, justamente a decisão de utilizar ou não gráficos para evidenciar as informações e a exemplo de Uyar (2011), que investigou a relação entre quantidade de gráficos utilizados e o desempenho financeiro e tamanho da empresa, Pen Rose (2008) também aponta que já que as instituições precisam decidir o que colocar nos seus informes narrativos, a situação financeira pode afetar essa decisão.

Segundo Galani et al (2011), a teoria em geral sugere que existe uma associação positiva entre a quantidade e qualidade das informações divulgadas e o desempenho financeiro das empresas. Uyar et al (2013) relaciona este fenômeno à teoria da agência e à teoria da sinalização. Para a teoria da agência, Soliman (2013) afirma que os gestores de companhias 
lucrativas evidenciam maior quantidade de informações para demonstrar aos stakeholders que eles agem em função dos melhores interesses do mercado, bem como para aumentar a confiança do investidor e manter a sua posição. Também são divulgadas maior quantidade de informações, segundo a teoria da sinalização, porque quando o desempenho financeiro é positivo, as empresas ficam mais inclinadas a sinalizar sua qualidade aos investidores (UYAR et al,2013).

Mather et al (2000) afirmam que um meio de investigar a presença de seletividade é analisando se a escolha das variáveis reportadas através de gráficos está relacionada ao desempenho das empresas. Nesse sentido, e em conformidade com os estudos de Steinbart (1989), Beattie e Jones (1992, 1997, 2000b), Mather et al (2000) que investigaram a seletividade em relação à inclusão de gráficos nos relatórios e a utilização de gráficos relativos às variáveis financeiras chaves, foram formuladas as seguintes hipóteses:

H1: Existe associação estatística significativa entre a quantidade de gráficos e o desempenho financeiro da empresa.

H2: Existe relação estatística significativa entre a quantidade de gráficos que reportam variáveis financeiras chaves (lucro líquido, receita líquida e dividendos) e o desempenho financeiro da empresa.

H3: Existe relação estatística significativa entre a quantidade de gráficos que reportam variáveis financeiras chaves e mudanças de situação no desempenho financeiro da empresa.

\subsubsection{Hipóteses relativas à Melhora de Apresentação}

Conforme defendem Muiño e Trombeta (2009), o tamanho da empresa é frequentemente utilizado como proxy da disponibilidade de informações (MURCIA; SANTOS, 2009; GONÇALVES, 2012; SOLIMAN, 2013; UYAR et al, 2014), dado que empresas maiores tendem a divulgar maior quantidade de informações que empresas menores.

Soliman (2013) afirma que isso ocorre porque companhias maiores enfrentam maiores custos de agência já que requerem maior volume de capital externo para financiar seus investimentos e que um nível melhor de disclosure reduz esses custos. Além disso, o custo de 
acumular e divulgar informações é maior para empresas menores (GALANI et al, 2011). Akerlorf (1970) afirma que ser avaliado no mercado como um "abacaxi” também implica em custos as empresas, e nesse sentido elas têm incentivos para divulgar melhores informações.

Em resumo, Diamond e Verrechia (1991) afirmam que é esperado que empresas maiores apresentem um disclosure de melhor qualidade, já que além dos custos menores, elas também atingem benefícios econômicos. Isto posto e levando em consideração, que um dos assuntos relativos à utilização de gráficos está relacionado ao fato de que os preparadores dos relatórios anuais podem deliberadamente violar alguns princípios de construção gráfica para transmitir uma impressão melhor da empresa ou dificultar a compreensão de determinadas informações (BEATTIE; JONES, 2008b), espera-se que companhias de maior porte utilizem menos recursos gráficos distorcidos.

Essa prática na literatura é chamada de melhora de apresentação e conforme apontado na plataforma teórica, pode ser verificada, por exemplo, através da presença de recursos tridimensionais ou do emprego de base maior que zero nos gráficos utilizados. Nesse sentido, e com base em pesquisas anteriores (MUIÑO; TROMBETA, 2009; UYAR, 2011; MOREIRA et al, 2011) que investigaram a relação entre o tamanho das empresas e a utilização de gráficos em relatórios financeiros, é apresentada a seguinte hipótese:

H4: Existe relação estatística negativa entre o tamanho da empresa e a quantidade de gráficos com realce ou melhora de apresentação empregados nos RAs de companhias abertas brasileiras. 


\section{PROCEDIMENTOS METODOLÓGICOS}

\subsection{Caracterização da Pesquisa}

Esta pesquisa é definida em relação ao método como hipotético-dedutiva, atendendo ao disposto por Prodanov (2013), partindo da proposição de um problema ou uma lacuna no conhecimento científico, passando pela formulação de hipóteses e por um processo de inferência dedutiva, no qual a predição da ocorrência de fenômenos abrangidos pelas referidas hipóteses é testada. Quanto à abordagem, trata-se de uma pesquisa empírico-analítica cujas investigações utilizam técnicas de registro de dados marcadamente quantitativas e existe uma relação direta de causa e efeito entre variáveis dependentes e independentes num processo que privilegia a descrição e a explicação dessa relação conduzindo a pesquisa ao conhecimento científico (GAMBOA, 1987).

A estratégia de pesquisa empregada é a documental, que segundo Martins (2009), é caracterizada por utilizar documentos como fonte de dados, informações e evidências, com fontes dos mais variados tipos. A fonte primária de coleta de dados foi feita por meio de análise qualitativa dos Relatórios da Administração das companhias abertas brasileiras. Portanto, a avaliação desse estudo é quanti-qualitativa incluindo não só a organização, sumarização e caracterização de dados numéricos coletados, mas também a análise simultânea desses dados e da mensagem transmitida por eles.

\subsection{Seleção da Amostra}

O universo deste estudo compreende 620 empresas identificadas com cadastro ativo no sítio da Comissão de Valores Mobiliários (CVM), em fevereiro de 2016. A população-alvo é definida por todas as companhias abertas brasileiras que não se encontram em situação de liquidação ou recuperação judicial e cujo pedido de abertura de capital tenha sido concedido até o ano de 1997. Foram encontradas 233 empresas com essas características pertencentes aos mais diversos setores de atuação conforme apontado pela Tabela 1: 
Tabela 1 - Quantidade de Empresas e Setor de Atuação

\begin{tabular}{l|c|l|r}
\hline \multicolumn{1}{c|}{ Setor de Atuação } & Quantidade & \multicolumn{1}{c|}{ Setor de Atuação } & Quantidade \\
\hline Alimentos & 3 & Hospedagem e Turismo & 4 \\
\hline Arrendamento Mercantil & 3 & Intermediação Financeira & 2 \\
\hline Bancos & 16 & Máquinas, Equipamentos, Veículos & 15 \\
\hline Brinquedos e Lazer & 2 & Metalurgia e Siderurgia & 22 \\
\hline Comércio (Atacado e Varejo) & 8 & Papel e Celulose & 5 \\
\hline Comunicação e Informática & 2 & Participação em outras sociedades & 2 \\
\hline Construção Civil, Mat. Constr. e & 19 & Pesca & 1 \\
Decoraçã & 2 & Petróleo e Gás & 2 \\
\hline Crédito Imobiliário & 1 & Petroquímicos e Borracha & 5 \\
\hline Embalagens & 53 & Saneamento, Serv. Água e Gás & 5 \\
\hline Emp. Adm. Part. (DIVERSOS) & 23 & Seguradoras e Corretoras & 2 \\
\hline Energia Elétrica & 3 & Serviços Transporte e Logística & 7 \\
\hline Extração Mineral & 1 & Telecomunicações & 4 \\
\hline Farmacêutico e Higiene & 1 & Têxtil e Vestuário & 20 \\
\hline Gráficas e Editoras & & $\mathbf{2 3 3}$ & \\
\hline TOTAL GERAL & &
\end{tabular}

Fonte: Pesquisa feita no sítio da CVM em 15 de fevereiro de 2016.

Também foi estabelecido como critério de seleção que todos os Relatórios da Administração estivessem disponibilizados anualmente no sítio da entidade no período dos 18 anos estabelecidos. Verificou-se então, que 42 empresas não atendiam a esse critério, por não apresentarem todos os RAs em algum dos anos ou, por em seu lugar, apresentarem outros arquivos, como por exemplo, Notas Explicativas e documentos em branco. Também foram identificadas 11 empresas que possuíam cadastro ativo concedido antes de 1997, mas que encontravam-se em situação de liquidação ou recuperação judicial e também foram excluídas da amostra final.

Tabela 2 - Seleção da Amostra

\begin{tabular}{l|c}
\hline \multicolumn{1}{c}{ Etapas } & Quantidade de Empresas \\
\hline População Inicial & 620 \\
\hline Registro Concedido até 1997 & 233 \\
\hline (-) Não apresentaram RA em todos os anos & 42 \\
\hline (-) Em liquidação/recuperação judicial & 11 \\
\hline = Total da Amostra & $\mathbf{1 8 0}$ \\
\hline
\end{tabular}

Após essa análise, restaram 180 empresas, totalizando 3.240 relatórios anuais referentes ao período de 1997 a 2014, que foram obtidos um a um no endereço eletrônico da CVM. É possível verificar na Tabela 3 a quantidade de empresas da amostra final por ano de abertura de suas atividades. 
Tabela 3 - Quantidade de empresas e ano de concessão do registro

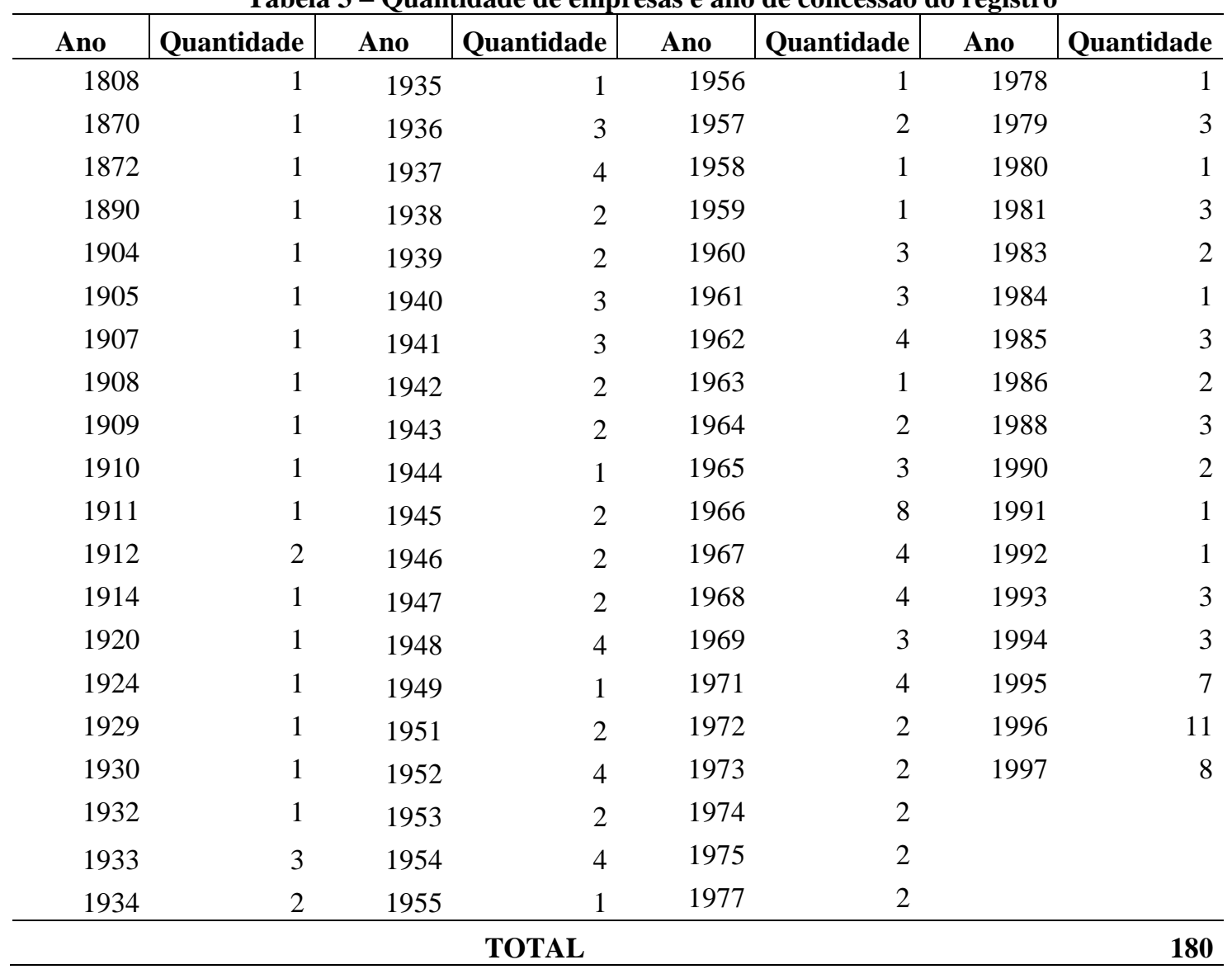

A empresa identificada com cadastro mais antigo é o Banco do Brasil S/A, que começou suas atividades no ano de 1808 e está ativo na Comissão de Valores Mobiliários desde 1977. O ano com em que a maioria das empresas começou suas atividades é o de 1996, em verificou-se a data de abertura de 11 companhias. Apesar de algumas empresas apresentarem mais de 200 anos de atuação e possuírem cadastro ativo na CVM há pelo menos 70 anos, a série temporal deste estudo só abrange 18 anos porque as informações financeiras das empresas só passaram a ser disponibilizada para consulta pela CVM a partir de 1997.

\subsection{Coleta e Tratamento dos Dados}

Após o estabelecimento da amostra final, além do setor de atuação e ano de registro, também foram levantadas informações dos relatórios quanto ao volume de informações divulgadas, tendo sido utilizado como proxy o tamanho dos relatórios em relação à quantidade de páginas e quantidade de palavras, essa última fornecida pela ferramenta "contar palavras" do Word. Em seguida, procedeu-se ao levantamento da quantidade de recursos visuais 
utilizados nos relatórios durante o período, definidos por gráficos, tabelas, ilustrações e fotos, afim de permitir a investigação da evolução do emprego desses itens ao longo dos anos.

A próxima etapa foi levantar as características referentes aos gráficos coletados. Primeiramente, eles foram classificados conforme as principais formas gráficas identificadas em relatórios financeiros e apontadas por Beattie e Jones (1992) como sendo barra, coluna, linha e setores, incluindo possíveis desdobramentos em cada categoria, como no caso dos gráficos setoriais, que podem englobar tanto gráficos no formato de pizza como no formato de rosca. Na Figura 3, é possível verificar as diferenças entre esses tipos de gráficos através de alguns exemplos extraídos de relatórios da administração de empresas integrantes da amostra.

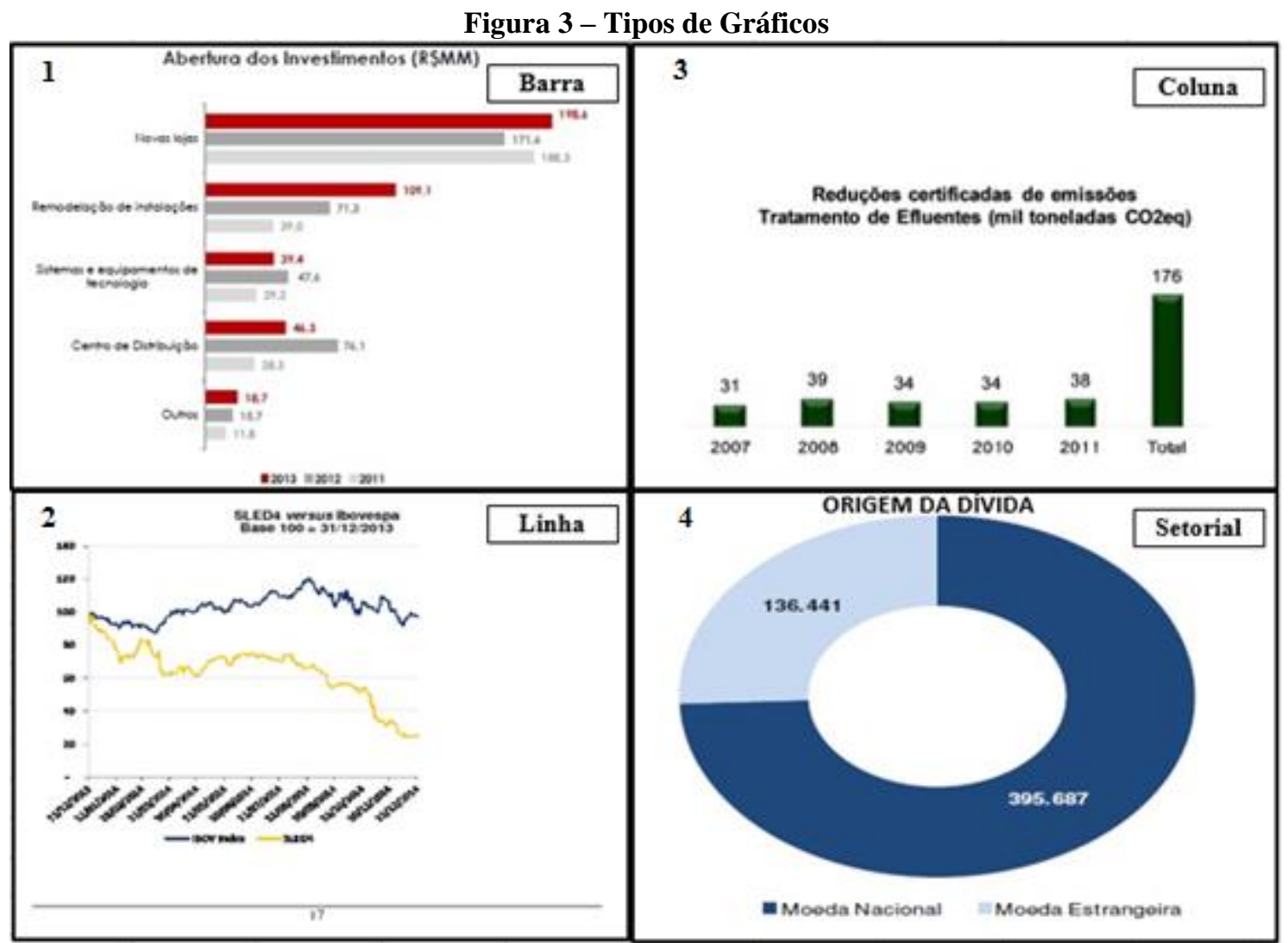

Fonte: Relatórios da Administração das Empresas -1) Lojas Renner S/A (2013, p.11); 2) Portobello S/A (2014, p.5); 3) Celulose Irani S/A (2013, p.16) e 4) Saraiva S/A (2014, p.17).

Além dos tipos de gráficos, também foram coletadas informações que configurassem alguma forma de melhora ou realce de apresentação, violando princípios de construção gráfica já apresentados. Foram estabelecidas como proxies a existência de linhas ou setas indicativas de escalas múltiplas, conforme pesquisa de Ferreira (2015). Também foram consideradas para análise estruturas tridimensionais e bases diferente de zero, correspondentes a violações de 
princípios gráficos propostas por Kosslyn (1989). Essa última característica foi mensurada apenas nos gráficos de barra, coluna e linha por questões estruturais.

Também foram considerados como detentores de algum realce de apresentação os gráficos que apresentaram excesso de informações com base no que dispõe Tufte (1983) sobre infidelidades gráficas, afirmando que gráficos do tipo setorial não devem ter mais que quatro fatias. Esse raciocínio foi estendido aos demais gráficos, pois foi observado que um mesmo gráfico pode representar um conjunto de dados diferentes entre si, que podem ser definidos como grupos de informações que representam o desempenho de determinada variável por um ou mais períodos (PENTEADO, 2013). Ou seja, um mesmo gráfico pode apresentar mais de uma informação e o excesso delas provoca distorções de apresentação.

Na Figura 4, é possível observar gráficos que apresentaram algum tipo de realce extraído de relatórios analisados na pesquisa.

Figura 4 - Tipos de Realce de Apresentação

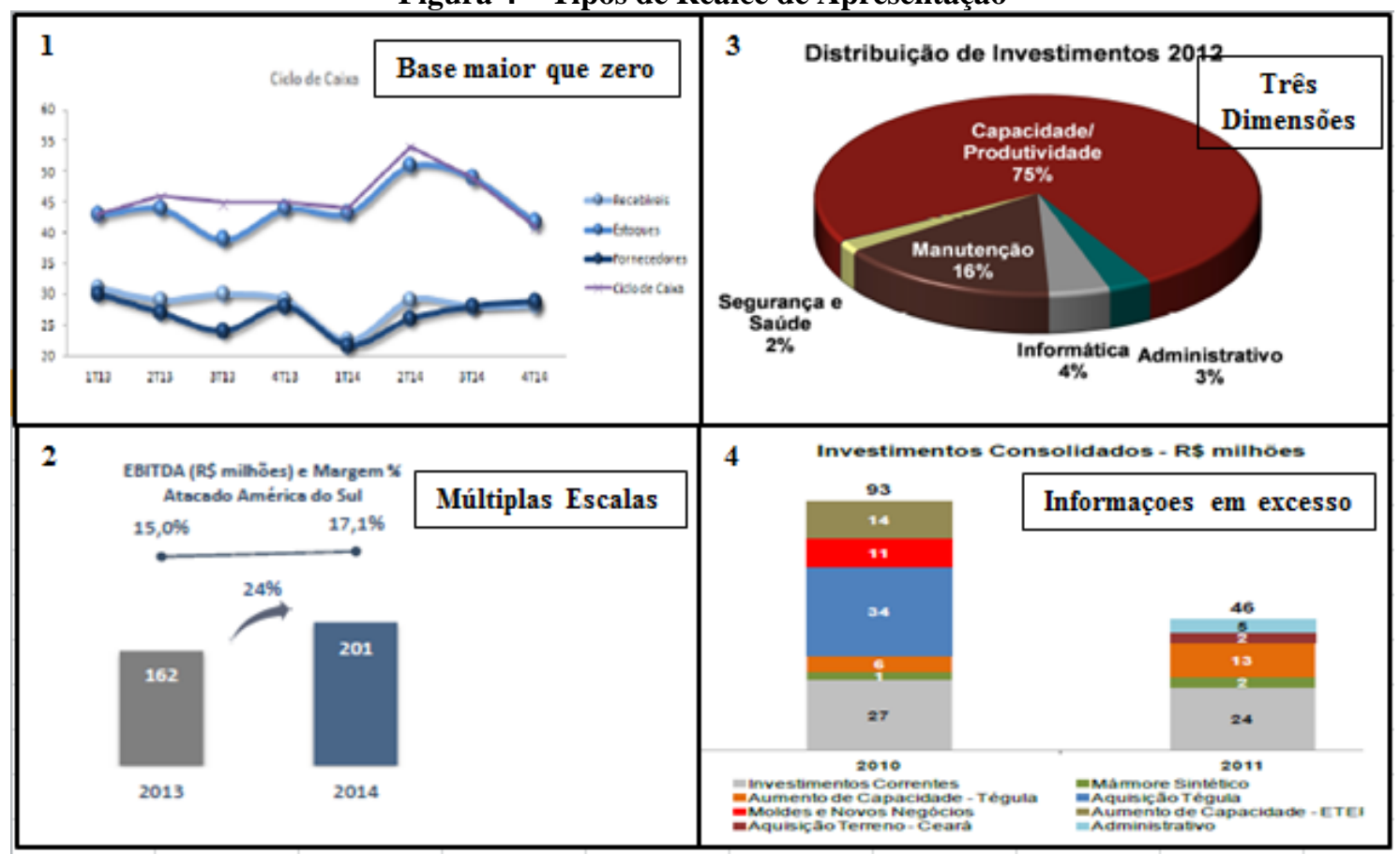

Fonte: Relatórios da Administração das Empresas: 1) Dimed S.A Distribuidora de Medicamentos (2014, p.11); 2) Coteminas S.A (2014, p.11); 3) Eternit S.A (2011, p.6); 4) Eternit S.A (2012, p.6);

O gráfico número 1 é um exemplo de gráfico de linha cuja base difere de zero, dando início ao eixo y com valor numérico superior. O segundo gráfico é do tipo coluna e apresenta realce de linha, com indicação de múltiplas escalas para uma mesma informação. O terceiro 
gráfico corresponde ao tipo setorial no formato de pizza e está apresentado em três dimensões. Já o último gráfico é um exemplo de excesso informacional que prejudica a análise do leitor por indicar dados relativos a nove itens de investimentos distintos.

Foi realizada ainda coleta do conteúdo reportado pelos recursos gráficos levantados. Inicialmente, os conteúdos indicados nos títulos de cada gráfico foram coletados e originaram uma primeira lista de conjuntos de variáveis, que em seguida foram agrupadas em oito grupos principais de conteúdos para facilitar a análise. As variáveis integrantes de cada grupo podem ser observadas conforme descritas no Quadro 2.

\begin{tabular}{|c|c|}
\hline \multicolumn{2}{|c|}{ Quadro 2 - Conteúdos Principais e Específicas } \\
\hline $\begin{array}{l}\text { CONTEÚDO } \\
\text { PRINCIPAL } \\
\end{array}$ & CONTEÚDOS ESPECÍFICOS \\
\hline RESULTADO & $\begin{array}{l}\text { Lucro Líquido, Lucro Bruto, Lucro Operacional, Ebtida, Prejuízo, } \\
\text { Margem Bruta, Indicadores de Resultados }\end{array}$ \\
\hline GASTOS & $\begin{array}{l}\text { Despesas, Depreciações, Custos dos Produtos Vendidos, Perdas } \\
\text { Técnicas e Comerciais, Inadimplência }\end{array}$ \\
\hline MERCADO & $\begin{array}{l}\text { Valorização das Ações, Operações de Crédito, Cenário Econômico, } \\
\text { Economia/Mercado, Exportações e Importações, Posição Financeira } \\
\text { Líquida, Preços }\end{array}$ \\
\hline PASSIVOS/DÍVIDA & Passivos, Obrigações, Endividamento \\
\hline RECURSOS & $\begin{array}{l}\text { Fonte de Recursos, Fluxo de caixa, Geração de caixa ou Depósitos, } \\
\text { Valor Adicionado }\end{array}$ \\
\hline PATRIMÔNIO & $\begin{array}{l}\text { Capital Social, Dividendos, Patrimônio Líquido, Remuneração dos } \\
\text { Acionistas, Sociedades }\end{array}$ \\
\hline ATIVOS & $\begin{array}{l}\text { Ativos, Consumidores/Clientes, Aplicações Financeiras, Estoques, } \\
\text { Investimentos }\end{array}$ \\
\hline RECEITAS & Receita Líquida, Receita Bruta, Volume de Vendas \\
\hline OUTROS & Variáveis específicas referentes ao setor de atuação. \\
\hline
\end{tabular}

Fonte: Elaboração Própria

Dentre os títulos condensados, foram separados também de maneira individual os gráficos que reportaram variáveis financeiras consideradas chave (VFC) com base nas pesquisas de Beattie e Jones (1992), Mather et al (1996) e Stainbart (1999), a fim de verificar se existe indícios de seletividade na escolha de quem elabora os relatórios ao reportar informações referentes ao lucro líquido, receita líquida e dividendos através de recursos gráficos. 
Para o tratamento desses dados, foi utilizada estatística descritiva como forma de organização e apresentação das quantidades de gráficos por ano, por setor de atuação da empresa, para os tipos de gráficos identificados e levantamento do desempenho financeiro. Dessa forma, foi possível calcular as médias, os desvios padrões e distribuições de frequência, que serviram de subsídio para os testes de significância seguintes.

\subsection{Análise da Seletividade Gráfica e Melhora da Apresentação}

A seletividade neste trabalho está voltada para a verificação da relação existente entre a escolha de utilização de gráficos/inclusão de variáveis e o desempenho financeiro. Para verificar se há relação entre a inclusão de gráficos no Relatório da Administração atrelada ao desempenho financeiro, será aplicado o teste de significância não paramétrico Qui-Quadrado, conforme metodologia de pesquisas anteriores (BEATTIE; JONES, 1992, 1997; MATHER et $a l, 1996)$. Este teste verifica se há adequação de ajustamento entre as frequências observadas e as frequências esperadas, ou seja, se há diferença significativa entre elas (MARTINS; THEÓPHILO, 2010). Nesse caso, o teste será feito para verificar a associação ou independência entre o desempenho financeiro e a utilização de informações gráficas ao nível de significância de 5\%. Caso seja constatada a dependência entre essas variáveis, então se rejeita-se a hipótese nula de que não há associação entre elas e aceita-se a hipótese 1 desta pesquisa, constatando-se indícios de gerenciamento de impressão na forma de seletividade gráfica.

Quanto ao segundo aspecto relacionado à seletividade, foi investigada a relação da quantidade de gráficos que reportavam variáveis financeiras-chave (VFC) a respeito do lucro líquido, receita líquida e dividendos das empresas e o desempenho financeiro, por meio de modelo econométrico a ser descrito no próximo subcapítulo. O mesmo método foi utilizado para identificação do gerenciamento de impressão com base na melhora ou realce de apresentação gráfica.

Foram adotadas como proxies dessa distorção a existência de gráficos em três dimensões, gráficos com base maior que zero, linhas indicativas de múltiplas escalas e excesso de informação. Para capturar essa informação e pela carência de pesquisas que explorem esse aspecto do gerenciamento de impressão, foi criada uma variável denominada GRMA. Foi levado em consideração que um mesmo gráfico pode apresentar mais de um tipo de infidelidade, logo afim de evitar uma dupla contagem do mesmo gráfico e suavizar valores extremos para que 
estes possam ser usados para previsão em séries temporais, foi desenvolvido o seguinte índice para ser testado como variável dependente, definido através da expressão:

$$
G R M A=\left(\frac{G 3 D}{T G}\right)+\left(\frac{G B>0}{T G}\right)+\left(\frac{G L}{T G}\right)+\left(\frac{G E}{T G}\right)
$$

Onde,

GRMA: Gráficos Com Realce ou Melhora de Apresentação;

G3D: Gráficos em três dimensões;

$G B>0$ : Gráficos com base maior que zero;

GL: Gráficos com linhas indicativas de múltiplas escalas;

$G E$ : Gráficos com excesso de informações;

$T G$ : Total de Gráficos.

\subsubsection{Variáveis Independentes e Modelos Econométricos}

Para a verificação das Hipóteses 2 e 3, relativas à variável dependente que indica a quantidade de gráficos que reportam variáveis financeiras-chave (VFC), foi utilizado o seguinte modelo econométrico:

$$
V F C_{i, t}=\alpha+\beta_{1} R O A_{i, t}+\beta_{2} V R_{i, t}+\beta_{3} L N I+\beta_{4} T A M R A_{i, t}+\beta_{5} T_{1}+\beta_{6} T_{3}+\varepsilon
$$

A variável $\mathrm{VFC} i, t$ foi obtida através do somatório dos gráficos de cada relatório que reportavam informações referentes unicamente ao lucro líquido, receita líquida e dividendos da entidade, identificados através do título apresentado por cada gráfico. Ou seja, os gráficos que reportavam outras informações não foram considerados para esta análise.

Já os aspectos relativos às distorções gráficas abordados pela Hipótese 4 desta pesquisa foram analisados através da seguinte equação:

$$
\text { GRMA }_{i_{i, t}}=\alpha+\beta_{1} \text { ROA }_{i_{i, t}}+\beta_{2} L_{N A T I V O} i_{i_{t} t}+\beta_{3} L N I+\beta_{4} T A M R A_{i_{i}, t}+\beta_{5} T_{1}+\beta_{6} T_{3}+\varepsilon
$$

O índice dado pelo cálculo do GRMA, empregado como variável dependente nesta pesquisa, foi obtido considerando-se todos os gráficos, independentemente do conteúdo 
reportado, mas que apresentaram algum tipo de melhora ou distorção de apresentação em relação à quantidade total de gráficos de cada relatório.

Para o desempenho e porte das empresas, as variáveis independentes utilizadas como proxies foram extraídas das demonstrações financeiras individuais das companhias integrantes da amostra e disponibilizadas no sítio eletrônico da CVM, a saber, Balanço Patrimonial e Demonstração do Resultado do Exercício. A partir delas, os índices utilizados no modelo foram calculados. As demais variáveis independentes foram extraídas dos próprios Relatórios da Administração e informações cadastrais disponibilizadas. No Quadro 3, estão discriminadas estas variáveis e suas descrições:

Quadro 3 - Descrição das Variáveis Independentes

\begin{tabular}{|c|c|c|}
\hline \multicolumn{2}{|c|}{ VARIÁVEIS } & DESCRIÇÃO \\
\hline Lucratividade & $\boldsymbol{R O A} i, t$ & $\begin{array}{l}\text { A associação entre a lucratividade e evidenciação de informações financeiras tem sido } \\
\text { amplamente investigada na literatura (INCHAUSTI, 1997), porque empresas com ganhos } \\
\text { maiores têm uma propensão maior de revelar suas "boas notícias" (CORMIER et al, 2011). } \\
\text { Nesse sentido, as pesquisas têm utilizado como medida de lucratividade o retorno sobre os } \\
\text { ativos (ROA), conforme visto em Bramer e Pavelin, (2008), Cormier et al (2011), Galani } \\
\text { et al (2011) e Mohamad (2014). Nesta pesquisa o ROA, calculado pela relação entre o } \\
\text { lucro líquido e o ativo, também foi empregado como proxy para lucratividade. }\end{array}$ \\
\hline $\begin{array}{c}\text { Melhora de Situação } \\
\text { Econômica }\end{array}$ & $V R i, t$ & $\begin{array}{l}\text { A variação de um ano para o outro do próprio lucro líquido foi empregada para captar } \\
\text { possível relação da inclusão de gráficos com mudanças de situação no desempenho, em } \\
\text { conformidade com a investigação de Steinbart (1989), Mather et al (1999),Beattie e Jones } \\
\text { (2000b) e Dilla e Javrin (2010) que analisaram se gráficos de variáveis financeiras chaves } \\
\text { eram incluídos com mais frequência quando o desempenho financeiro da empresa havia } \\
\text { melhorado em relação ao exercício anterior. Esta variável foi obtida através da variação do } \\
\text { lucro líquido de um período para o outro. }\end{array}$ \\
\hline $\begin{array}{l}\text { Tamanho da } \\
\text { Empresa }\end{array}$ & $\underset{i, t}{\operatorname{LnATIVO}}$ & $\begin{array}{l}\text { Moreira et al (2011) afirma que as empresas maiores são mais estruturadas para gerar e } \\
\text { divulgar suas informações financeiras, além de terem mais interesse, que as menores no } \\
\text { relacionamento com seus stakeholders. Nesse sentido, diversas pesquisas têm analisado a } \\
\text { relação entre o tamanho da empresa e a divulgação de informações e tem sido observado o } \\
\text { emprego de diferentes medidas para o tamanho da companhia na literatura, como receitas, } \\
\text { quantidade de empregados e ativos (BINI et al, 2011). Nessa pesquisa, alinhado a Brammer } \\
\text { e Pavelin (2008), Uyar (2011), Galani (2011), e Moreira et al (2011), foi utilizado o } \\
\text { logaritmo natural do ativo total de cada ano como proxy para tamanho da empresa. }\end{array}$ \\
\hline
\end{tabular}




\begin{tabular}{|c|c|c|}
\hline Idade da Empresa & $\operatorname{LnI} i, t$ & $\begin{array}{l}\text { Segundo Akhtaruddin (2005), a racionalidade desta variável está na possibilidade de que } \\
\text { empresas mais antigas tenham desenvolvido melhor suas práticas de divulgação em função } \\
\text { do tempo e que exista um interesse dessas empresas em fortalecer a sua reputação e imagem } \\
\text { no mercado. Nesse sentido, é esperado que exista uma associação positiva entre a idade da } \\
\text { companhia e a quantidade e qualidade das informações divulgadas voluntária e } \\
\text { compulsoriamente (HASAN; HOSAIN, 2015). Diante disso, essa característica têm sido } \\
\text { utilizada como variável de controle para relação positiva entre a idade das companhias e } \\
\text { padrões de divulgação em diversas pesquisas realizadas em mercados emergentes, a } \\
\text { exemplo de Choi (1973), Owosu (2005), Uyar et al (2012), Popova et al (2013), Ferchichi } \\
\text { (2013), e com base nesses estudos e em Roberts (1992), Soleman (2013) e Galani (2011) } \\
\text { estabeleceu-se como proxy de medida o logaritmo natural da idade de cada empresa. }\end{array}$ \\
\hline $\begin{array}{l}\text { Período de } \\
\text { Publicaçãao }\end{array}$ & $T$ & $\begin{array}{l}\text { Partindo de Pesquisas que objetivaram verificar a evolução da divulgação de informações } \\
\text { ao longo do tempo (BEUREN, 1988; ALMEIDA, 1991) e da premissa de que com o passar } \\
\text { dos anos, as empresas divulgaram mais informações e mais gráficos, estabeleceu-se essa } \\
\text { variável dummy de controle com base no trabalho de Rodrigues (2012), onde para o período } \\
\text { T1, compreendido entre } 1997 \text { a 2002, assumiu-se 1; para os demais períodos T2 (2003 a } \\
\text { 2008) e T3 (2009 - 2014) assumiu-se 0. }\end{array}$ \\
\hline $\begin{array}{c}\text { Tamanho do } \\
\text { Relatório }\end{array}$ & $T A M R i, t$ & $\begin{array}{l}\text { Milne e Adler (1999) apontam que uma das unidades de medidas da divulgação de } \\
\text { informações é o tamanho dos relatórios das empresas, que podem ser medidos pela } \\
\text { quantidade de páginas, palavras ou quantidade de frases. Assim, estabeleceu-se o tamanho } \\
\text { do relatório da administração como variável de controle, já que espera-se uma relação } \\
\text { positiva entre a quantidade de gráficos e o volume de informações, utilizando-se como } \\
\text { proxy para tamanho a quantidade de palavras conforme observado nos trabalhos de } \\
\text { Rodrigues (2012) e Silva } \text { et al (2007), }\end{array}$ \\
\hline
\end{tabular}




\section{RESULTADOS}

\subsection{Caracterização das Empresas e Análise Descritiva dos Relatórios}

Como apontado anteriormente, a amostra é composta por 180 companhias abertas de diversos setores de atuação. Para possibilitar a análise deste estudo, e com base nas pesquisas de Rodrigues (2012) e Penteado (2013), esses setores foram agrupados em seis conjuntos da seguinte maneira: i)Adm e Participações (emp. adm participações, participação em outras sociedades); ii) Comércio (alimentos, brinquedos e lazer, comércio - atacado e varejo, farmacêutico e higiene, gráficas e editoras, têxtil e vestuário); iii) Construção e infraestrutura (Construção civil, material de construção e decoração, extração mineral, petróleo e gás, petroquímicos e borracha, metalurgia e siderurgia, papel e celulose, máquinas, equipamentos, veículos e peças); iv) Financeiro (bancos, crédito imobiliário, intermediação financeira, arrendamento mercantil); v) Serviços (hospedagem e turismo, seguradoras e corretoras, comunicação e informática, serviços, transporte e logística); vi) Utilidade Pública ( saneamento, serv. água e gás, telecomunicações, energia elétrica). Para essa divisão, foram levados em consideração aspectos que influenciam os padrões de publicação, já que, por exemplo, empresas altamente reguladas, devido às exigências legais, tendem a divulgar maior quantidade de informações. Na Tabela 4, é possível verificar a distribuição das empresas analisadas por setor de atuação:

Tabela 4 - Setor de Atuação das Empresas

\begin{tabular}{lcc}
\hline \multicolumn{1}{c}{ Setor de Atuação } & Quantidade & \% \\
\hline Adm. e Participações & 46 & 26,0 \\
Comércio & 23 & 13,0 \\
Construção Infra Estrutura & 58 & 32,0 \\
Financeiro & 17 & 9,0 \\
Serviços & 10 & 6,0 \\
Utilidade Pública & 26 & 14,0 \\
\hline Total & $\mathbf{1 8 0}$ & $\mathbf{1 0 0}$ \\
\hline Fonte: Pesquisa feita no sítio da CVM em 15 de fevereiro de 2016.
\end{tabular}

A maioria das empresas integra a categoria de Construção e Infraestrutura, o que corresponde a $32 \%$ da amostra, sendo que das 58 empresas identificadas, 20 delas são do setor de Metalurgia e Siderurgia. Apesar dessa categoria ser a mais expressiva, o setor denominado Administração e Participação apresentou 46 empresas, sendo essa a maior quantidade de empresas pertencentes a um mesmo setor que está composto da seguinte forma: Alimentos (2); 
Comércio (atacado e varejo) (1); Construção Civil, Materiais de Construção e Decoração (1); Embalagens (1); Energia Elétrica (3); Extração Mineral (1); Hospedagem e Turismo (1); Intermediação Financeira (1); Máquinas, Equipamentos, Veículos e Peças (3); Metalurgia e Siderurgia (2); Papel e Celulose (2); Petroquímicos e Borracha (1); Saneamento, Serv. Água e Gás (1); Sem Setor Principal (19); Serviços Transporte e Logística (1); Telecomunicações (2) e Têxtil e Vestuário (2).

Quanto ao tamanho dos relatórios dessas empresas, a Tabela 5 demonstra a estatística descritiva por setor de atuação da quantidade de palavras utilizadas pelos relatórios das 180 empresas no período, no total de 3.240 observações.

Tabela 5 -Quantidade de Palavras por Setor

\begin{tabular}{lcccccc}
\hline \multicolumn{1}{c}{ Setor de Atuação } & Média & $\begin{array}{c}\text { Desvio } \\
\text { Padrão }\end{array}$ & Mínimo & Máximo & Assimetria & Curtose \\
\hline Adm. e Participações & $1.416,71$ & $2.270,03$ & 34 & 22.044 & 3,53 & 18,35 \\
Comércio & $2.305,20$ & $2.133,58$ & 26 & 9.626 & 1,62 & 2,17 \\
Construção Infra Estrutura & $2.339,32$ & $2.716,35$ & 40 & 21.413 & 2,24 & 7,14 \\
Financeiro & $3.051,20$ & 4043,53 & 23 & 18.565 & 2,08 & 3,86 \\
Serviços & $1.470,94$ & $3.574,97$ & 27 & 24.539 & 4,4 & 20,05 \\
Utilidade Pública & $5.550,87$ & $4.995,86$ & 90 & 56.184 & 3,56 & 25,60 \\
\hline
\end{tabular}

Como é possível observar, a categoria cujas empresas apresentaram os relatórios mais extensos foi a de Utilidade Pública, com uma média de 5.550,87 palavras por relatório, sendo o maior deles divulgado pela Companhia Energética de Brasília - CEB (Setor Energia Elétrica) no ano de 2014, com 56.184 palavras. Já os relatórios menos volumosos pertencem aos setores de Emp. Adm. e Part e Participações em Outras Sociedades, com média de 1.416,71 palavras. No entanto, o menor relatório das 3.240 observações foi divulgado por uma empresa do conjunto de setores Financeiro, no ano de 1998, a Neumarkt Financial and Financial Center S.A, pertencente ao setor de Crédito Imobiliário.

Na Tabela 6, também é possível visualizar a evolução da quantidade média de palavras dos relatórios por ano de divulgação:

Tabela 6 - Quantidade de Palavras por ano

\begin{tabular}{ccccccc}
\hline Ano & Média & Desvio Padrão & Mínimo & Máximo & Assimetria & Curtose \\
\hline 1997 & $1.260,06$ & $1.357,77$ & 56 & 9405 & 2,40 & 8,29 \\
1998 & $1.352,34$ & $1.526,79$ & 23 & 12355 & 3,01 & 15,08 \\
1999 & $1.444,52$ & $1.511,98$ & 40 & 7349 & 1,65 & 2,59
\end{tabular}




\begin{tabular}{ccccccc}
2000 & $1.504,28$ & $1.696,81$ & 40 & 9109 & 1,98 & 4,28 \\
2001 & $1.788,93$ & $2.114,76$ & 28 & 11589 & 2,02 & 4,69 \\
2002 & $1.856,62$ & $2.499,60$ & 36 & 18300 & 3,52 & 17,59 \\
2003 & $2.050,03$ & $2.556,52$ & 31 & 17538 & 2,41 & 8,07 \\
2004 & $2.397,16$ & $3.095,74$ & 31 & 20534 & 2,26 & 6,80 \\
2005 & $2.466,87$ & $3.023,03$ & 26 & 19267 & 2,15 & 6,10 \\
2006 & $2.587,59$ & $3.319,17$ & 34 & 24539 & 2,64 & 10,89 \\
2007 & $2.832,28$ & $3.201,73$ & 27 & 15840 & 1,67 & 2,55 \\
2008 & $2.884,23$ & $3.570,95$ & 27 & 19667 & 2,18 & 5,22 \\
2009 & $2.999,72$ & $3.630,03$ & 38 & 21306 & 2,33 & 6,78 \\
2010 & $3.515,86$ & $4.285,83$ & 28 & 22959 & 2,06 & 4,75 \\
2011 & $3.292,93$ & $3.777,89$ & 28 & 26672 & 2,33 & 8,66 \\
2012 & $3.412,56$ & $4.052,12$ & 59 & 21449 & 2,13 & 5,54 \\
2013 & $3.592,47$ & $5.601,45$ & 59 & 56184 & 5,30 & 43,20 \\
2014 & $3.555,94$ & $4.632,27$ & 59 & 29604 & 2,61 & 8,90 \\
\hline
\end{tabular}

Observando-se os dados apresentados, verifica-se que houve uma evolução no volume destes relatórios, sendo o ano de 1997 o que apresentou a menor média de palavras enquanto os anos de 2013 e 2014 apresentaram os relatórios mais extensos, com as maiores médias e também com a maior quantidade de palavras: 56.184 palavras em 2013 e, 29.604 em 2014. Conforme já informado, o menor relatório da amostra foi divulgado por empresa do setor de Crédito Imobiliário e trazia apenas a seguinte frase: "A sociedade apresenta no exercício um Prejuízo Líquido de $\mathrm{R}$ \$ 697.239,00. Ficamos à disposição dos Senhores Acionistas, para quaisquer esclarecimentos que julgarem necessários."

Também foi efetuada a análise dos recursos visuais presentes nos relatórios objeto desta verificação. Foi constatado que, dos 3.240 relatórios, 1.593 não empregaram qualquer tipo de recurso visual para o período de 1997 a 2014. Esse número é um pouco maior em relação à quantidade de recursos gráficos, já que 2.184 relatórios, ou seja, aproximadamente $67 \%$ da amostra não apresentaram qualquer tipo de gráfico.

Foram encontrados 16.936 recursos visuais nos 3.240 relatórios. Destes, aproximadamente $45,3 \%$ correspondiam a recursos gráficos, totalizando 7.669 gráficos. O montante de tabelas no valor de 8.634 representa $51 \%$ da quantidade de recursos visuais totais utilizados enquanto as ilustrações correspondem a aproximadamente $3,25 \%$, num montante de 173 recursos que incluem organogramas, fotos, mapas de atuação geográfica e selos de prêmios/representações. Foram identificadas apenas 82 fotos em todo período de análise e a quantidade total de todos os recursos visuais identificados por ano está apresentada na Tabela 7 a seguir: 
Tabela 7 - Quantidade de Recursos Visuais por Ano

\begin{tabular}{|c|c|c|c|c|c|c|c|c|c|c|c|c|c|c|}
\hline \multirow{2}{*}{ Ano } & \multicolumn{3}{|c|}{ Gráficos } & \multicolumn{3}{|c|}{ Tabelas } & \multicolumn{3}{|c|}{ Ilustrações } & \multicolumn{3}{|c|}{ Fotos } & \multirow{2}{*}{$\begin{array}{l}\text { Total } \\
\text { Geral }\end{array}$} & \multirow{2}{*}{$\%$} \\
\hline & Méd & Máx & Total & Méd & Máx & Total & Méd & Máx & Total & Méd & Máx & Total & & \\
\hline 1997 & 0,49 & 16 & 88 & 1 & 10 & 180 & 0 & 0 & 0 & 0 & 0 & 0 & 268 & 1,58 \\
\hline 1998 & 0,44 & 12 & 79 & 1,09 & 13 & 196 & 0,01 & 1 & 1 & 0 & 0 & 0 & 276 & 1,63 \\
\hline 1999 & 0,73 & 13 & 131 & 1,28 & 14 & 231 & 0,02 & 1 & 3 & 0 & 0 & 0 & 365 & 2,16 \\
\hline 2000 & 0,89 & 17 & 161 & 1,51 & 11 & 272 & 0,05 & 3 & 9 & 0 & 0 & 0 & 442 & 2,61 \\
\hline 2001 & 1,18 & 13 & 212 & 1,77 & 16 & 319 & 0,06 & 3 & 11 & 0,01 & 1 & 1 & 543 & 3,21 \\
\hline 2002 & 1,41 & 17 & 253 & 1,89 & 26 & 341 & 0,07 & 3 & 13 & 0,01 & 1 & 1 & 608 & 3,59 \\
\hline 2003 & 1,72 & 20 & 309 & 2,21 & 23 & 397 & 0,14 & 5 & 25 & 0 & 0 & 0 & 731 & 4,32 \\
\hline 2004 & 2,18 & 24 & 393 & 2,32 & 26 & 417 & 0,09 & 3 & 17 & 0 & 0 & 0 & 827 & 4,88 \\
\hline 2005 & 2,56 & 21 & 461 & 2,25 & 24 & 405 & 0,14 & 4 & 26 & 0 & 0 & 0 & 892 & 5,27 \\
\hline 2006 & 2,56 & 21 & 461 & 2,66 & 35 & 478 & 0,26 & 10 & 46 & 0 & 0 & 0 & 985 & 5,82 \\
\hline 2007 & 2,89 & 20 & 521 & 2,91 & 35 & 523 & 0,24 & 15 & 44 & 0 & 0 & 0 & 1088 & 6,42 \\
\hline 2008 & 2,87 & 29 & 516 & 3,01 & 55 & 541 & 0,28 & 11 & 50 & 0,03 & 4 & 5 & 1112 & 6,57 \\
\hline 2009 & 3,31 & 75 & 596 & 3,5 & 50 & 630 & 0,31 & 10 & 55 & 0,05 & 9 & 9 & 1290 & 7,62 \\
\hline 2010 & 4,12 & 36 & 742 & 4,1 & 42 & 738 & 0,34 & 10 & 61 & 0,06 & 10 & 11 & 1552 & 9,16 \\
\hline 2011 & 3,8 & 32 & 684 & 3,59 & 64 & 646 & 0,24 & 7 & 43 & 0,07 & 7 & 12 & 1385 & 8,18 \\
\hline 2012 & 3,73 & 36 & 672 & 4 & 62 & 720 & 0,32 & 10 & 57 & 0,06 & 5 & 11 & 1460 & 8,62 \\
\hline 2013 & 3,83 & 33 & 690 & 4,51 & 138 & 811 & 0,25 & 7 & 45 & 0,11 & 12 & 19 & 1565 & 9,24 \\
\hline 2014 & 3,89 & 45 & 700 & 4,38 & 51 & 789 & 0,25 & 7 & 45 & 0,07 & 9 & 13 & 1547 & 9,13 \\
\hline \multicolumn{3}{|c|}{ Total } & 7.669 & \multicolumn{2}{|c|}{ Total } & 8.634 & \multicolumn{2}{|c|}{ Total } & 551 & \multicolumn{2}{|c|}{ Total } & 82 & 16.936 & 100,00 \\
\hline
\end{tabular}

É possível perceber que assim como a quantidade de palavras empregadas, a utilização de recursos visuais também foi crescente ao longo dos anos. Enquanto o total geral utilizado em 1997 equivale a apenas 1,58 \% do montante de 16.936 itens. Também foi possível averiguar que a quantidade de empresas que não empregavam esses recursos em seus relatórios diminui com o passar dos anos. No ano de 1997, foram identificadas 116 empresas que não empregaram qualquer tipo de gráfico, tabelas, ilustrações ou fotos, já em 2014 apenas 67 empresas divulgaram relatórios contendo unicamente recursos narrativos. Na tabela 8 , também é possível verificar a quantidade e distribuição desses elementos por setor de atuação:

Tabela 8 - Quantidade de Recursos Visuais por Setor de Atuação

\begin{tabular}{|c|c|c|c|c|c|c|c|c|c|c|c|c|c|c|}
\hline \multirow{2}{*}{ Setor de Atuação } & \multicolumn{3}{|c|}{ Gráficos } & \multicolumn{3}{|c|}{ Tabelas } & \multicolumn{3}{|c|}{ Ilustrações } & \multicolumn{3}{|c|}{ Fotos } & \multirow{2}{*}{ Total } & \multirow{2}{*}{$\%$} \\
\hline & Méd & Máx & Total & Méd & Máx & Total & Méd & Máx & Total & Méd & Máx & Total & & \\
\hline Adm. e Participações & 1,28 & 28 & 1.060 & 1,8 & 36 & 1.492 & 0,07 & 5 & 65 & 0 & 1 & 1 & 2.618 & $15 \%$ \\
\hline Comércio & 3,47 & 75 & 1.438 & 3,19 & 34 & 1.322 & 0,13 & 7 & 58 & 0,1 & 12 & 41 & 2.859 & $17 \%$ \\
\hline $\begin{array}{l}\text { Construção e } \\
\text { Infraestrutura }\end{array}$ & 3,53 & 36 & 2.520 & 2 & 26 & 2.148 & 0,33 & 15 & 169 & 0.05 & 5 & 19 & 4.856 & $29 \%$ \\
\hline Financeiro & 1,57 & 35 & 481 & 1 & 9 & 249 & 0,08 & 5 & 28 & 0,01 & 1 & 3 & 761 & $4 \%$ \\
\hline Serviços & 0,66 & 16 & 131 & 0 & 6 & 73 & 0,08 & 5 & 19 & 0 & 0 & 0 & 223 & $1 \%$ \\
\hline Utilidade Pública & 4,53 & 33 & 2.039 & 7 & 138 & 3.350 & 0,45 & 10 & 212 & 0,04 & 9 & 18 & 5.619 & $33 \%$ \\
\hline & \multicolumn{2}{|c|}{ Total } & 7.669 & \multicolumn{2}{|c|}{ Total } & 8.634 & \multicolumn{2}{|c|}{ Total } & 551 & \multicolumn{2}{|c|}{ Total } & 82 & 16.936 & $100 \%$ \\
\hline
\end{tabular}

Através dessa análise, verifica-se que os setores que mais empregam recursos visuais estão inseridos na categoria de Utilidade Pública, que utilizaram $33 \%$ do total de itens levantados. Em contrapartida, as empresas de Serviços apresentaram apenas 223 recursos 
visuais em seus relatórios, porém isto pode ser atribuído ao fato de esta ser a categoria de setor com a menor quantidade de empresas.

Dentre as empresas analisadas, a Companhia Energética de Brasília, holding de geração e distribuição de energia, pertencente ao setor de Energia Elétrica, com cadastro ativo na CVM desde 1994 e constituída em 1968, foi a empresa que apresentou a maior quantidade de recursos visuais totais e também a maior quantidade de tabelas no relatório de um único ano, sendo 2 gráficos, 138 tabelas, 1 ilustração e 1 foto, totalizando 142 recursos utilizados no relatório da administração do exercício de 2013. Já a empresa Centrais Elétricas Brasileiras S/A, do mesmo setor de atuação e com cadastro ativo na CVM desde 1971 foi a empresa que apresentou o maior número de recursos visuais somados no período, com um montante de 766 tabelas, gráficos e ilustrações. A empresa Vulcabrás S/A, inserida na categoria de Comércio e pertencente ao setor Têxtil e Vestuário foi a empresa que mais utilizou gráficos em 2009, com um total de 75 itens em um único relatório e também apresentou 12 fotos, a maior quantidade em um único exercício, no ano de 2013. Por fim, a empresa pertencente ao setor de Papel e Celulose, a Celulose Irani S/A foi a que mais empregou ilustrações, sendo 15 dos 41 recursos visuais identificados no seu relatório do exercício de 2008.

Por fim, foi efetuada a análise do desempenho financeiro dos 3.240 exercícios, para em seguida, relacioná-los à utilização de gráficos nos relatórios anuais. Verificou-se que no período compreendido entre 1997 e 2014, 66,54\% dos relatórios divulgados referiam-se a empresas que reportaram lucro no exercício, conforme apresentado na Tabela 9.

Tabela 9 - Quantidade de Gráficos por Desempenho

\begin{tabular}{|c|c|c|c|c|c|c|c|c|}
\hline \multirow[b]{2}{*}{ Ano } & \multicolumn{4}{|c|}{ Lucro } & \multicolumn{4}{|c|}{ Prejuízo } \\
\hline & $\begin{array}{l}\text { Qtde } \\
\text { RAS }\end{array}$ & $\begin{array}{c}\text { Qtde } \\
\text { RAS c/ Gráficos }\end{array}$ & $\%$ & $\begin{array}{c}\text { Qtde } \\
\text { Gráficos }\end{array}$ & $\begin{array}{l}\text { Qtde } \\
\text { RAS }\end{array}$ & $\begin{array}{c}\text { Qtde } \\
\text { RAS c/ Gráficos }\end{array}$ & $\%$ & $\begin{array}{c}\text { Qtde } \\
\text { Gráficos }\end{array}$ \\
\hline 1997 & 114 & 10 & $9 \%$ & 50 & 66 & 8 & $12 \%$ & 38 \\
\hline 1998 & 107 & 12 & $11 \%$ & 47 & 73 & 7 & $10 \%$ & 32 \\
\hline 1999 & 103 & 20 & $19 \%$ & 77 & 77 & 13 & $17 \%$ & 54 \\
\hline 2000 & 115 & 26 & $23 \%$ & 120 & 65 & 8 & $12 \%$ & 41 \\
\hline 2001 & 118 & 31 & $26 \%$ & 150 & 62 & 13 & $21 \%$ & 62 \\
\hline 2002 & 98 & 26 & $27 \%$ & 140 & 82 & 24 & $29 \%$ & 113 \\
\hline 2003 & 119 & 42 & $35 \%$ & 230 & 61 & 16 & $26 \%$ & 79 \\
\hline 2004 & 132 & 49 & $37 \%$ & 346 & 48 & 9 & $19 \%$ & 47 \\
\hline 2005 & 126 & 54 & $43 \%$ & 395 & 54 & 12 & $22 \%$ & 66 \\
\hline 2006 & 132 & 55 & $42 \%$ & 426 & 48 & 8 & $17 \%$ & 35 \\
\hline 2007 & 135 & 63 & $47 \%$ & 463 & 45 & 10 & $22 \%$ & 58 \\
\hline
\end{tabular}




\begin{tabular}{ccccc|cccc}
2008 & 125 & 57 & $46 \%$ & 418 & 55 & 17 & $31 \%$ & 98 \\
2009 & 140 & 71 & $51 \%$ & 572 & 40 & 8 & $20 \%$ & 24 \\
2010 & 132 & 71 & $54 \%$ & 677 & 48 & 10 & $21 \%$ & 65 \\
2011 & 121 & 62 & $51 \%$ & 522 & 59 & 17 & $29 \%$ & 162 \\
2012 & 105 & 54 & $51 \%$ & 477 & 75 & 25 & $33 \%$ & 195 \\
2013 & 120 & 58 & $48 \%$ & 551 & 60 & 17 & $28 \%$ & 139 \\
2014 & 114 & 54 & $47 \%$ & 562 & 66 & 19 & $29 \%$ & 138 \\
\hline Total & 2156 & 815 & $38 \%$ & 6223 & 1084 & 241 & $22 \%$ & 1446 \\
\hline
\end{tabular}

Dos 2156 relatórios que reportaram lucro no exercício, 38\% deles fez uso de recursos gráficos, enquanto apenas 241 relatórios dos 1.084 referentes a exercícios com desempenho financeiro negativo utilizaram esses elementos. Também é possível perceber uma evolução na utilização desses recursos com o passar dos anos, especialmente no que diz respeito às empresas lucrativas. Isso porque para o ano de 1997, apenas 9\% dos 114 relatórios tinham qualquer tipo de recurso gráfico, enquanto que para os anos de 2009, 2010, 2011 e 2012, mais da metade dos relatórios de cada exercício fazia uso desse tipo de recurso. Também foi possível verificar que dos 7.669 gráficos coletados, 6.223 deles estavam empregados em relatórios da administração de anos que reportaram lucro, ou seja, $81 \%$ do total de gráficos levantados.

\subsection{Análise Descritiva dos Recursos Gráficos}

Os recursos gráficos foram classificados em quatro formas básicas, sendo elas: barras, colunas, linhas e setorial. O tipo de gráfico mais utilizado foi o de Coluna, com um total de 2.861 itens, o que representa $37 \%$ do total de gráficos apresentados. Os gráficos do tipo Linha são os menos utilizados, com apenas 627 deles nos relatórios do período. Na tabela 10, estão apresentadas as quantidade de cada tipo de gráfico por ano:

Tabela 10 - Tipos de Gráfico

\begin{tabular}{|c|c|c|c|c|c|c|c|c|c|c|c|c|}
\hline \multirow[t]{2}{*}{ Ano } & \multicolumn{3}{|c|}{ Barra } & \multicolumn{3}{|c|}{ Coluna } & \multicolumn{3}{|c|}{ Linha } & \multicolumn{3}{|c|}{ Setorial } \\
\hline & Méd & Máx & Total & Méd & Máx & Total & Méd & Máx & Total & Méd & Máx & Total \\
\hline 1997 & 0,039 & 3 & 7 & 0,206 & 14 & 37 & 0,000 & 0 & 0 & 0,244 & 12 & 44 \\
\hline 1998 & 0,100 & 6 & 18 & 0,144 & 4 & 26 & 0,006 & 1 & 1 & 0,172 & 10 & 31 \\
\hline 1999 & 0,172 & 9 & 31 & 0,200 & 6 & 36 & 0,089 & 10 & 16 & 0,261 & 8 & 47 \\
\hline 2000 & 0,194 & 8 & 35 & 0,278 & 7 & 50 & 0,194 & 7 & 35 & 0,228 & 8 & 41 \\
\hline 2001 & 0,322 & 9 & 58 & 0,339 & 6 & 61 & 0,167 & 3 & 30 & 0,350 & 8 & 63 \\
\hline 2002 & 0,400 & 9 & 72 & 0,461 & 10 & 83 & 0,178 & 5 & 32 & 0,367 & 6 & 66 \\
\hline 2003 & 0,458 & 8 & 82 & 0,676 & 17 & 121 & 0,196 & 5 & 35 & 0,380 & 7 & 68 \\
\hline 2004 & 0,528 & 11 & 95 & 0,917 & 21 & 165 & 0,256 & 4 & 46 & 0,478 & 9 & 86 \\
\hline 2005 & 0,628 & 9 & 113 & 1,122 & 19 & 202 & 0,183 & 4 & 33 & 0,606 & 19 & 109 \\
\hline
\end{tabular}




\begin{tabular}{ccccccccccccc}
2006 & 0,656 & 10 & 118 & 1,000 & 19 & 180 & 0,228 & 5 & 41 & 0,672 & 19 & 121 \\
2007 & 0,911 & 14 & 164 & 1,011 & 13 & 182 & 0,244 & 5 & 44 & 0,706 & 19 & 127 \\
2008 & 0,844 & 13 & 152 & 1,122 & 17 & 202 & 0,222 & 8 & 40 & 0,672 & 21 & 121 \\
2009 & 0,978 & 15 & 176 & 1,444 & 69 & 260 & 0,228 & 6 & 41 & 0,644 & 11 & 116 \\
2010 & 1,553 & 31 & 278 & 1,341 & 17 & 240 & 0,279 & 4 & 50 & 0,950 & 18 & 170 \\
2011 & 1,406 & 27 & 253 & 1,244 & 15 & 224 & 0,261 & 5 & 47 & 0,867 & 14 & 156 \\
2012 & 1,239 & 25 & 223 & 1,433 & 26 & 258 & 0,256 & 7 & 46 & 0,783 & 12 & 141 \\
2013 & 1,144 & 18 & 206 & 1,517 & 24 & 273 & 0,239 & 7 & 43 & 0,906 & 13 & 163 \\
2014 & 1,246 & 29 & 224 & 1,447 & 26 & 261 & 0,257 & 7 & 47 & 0,922 & 16 & 168 \\
\hline \multicolumn{1}{c}{ Total } & $\mathbf{2 3 0 5}$ & Total & $\mathbf{2 8 6 1}$ & Total & $\mathbf{6 2 7}$ & Total & $\mathbf{1 8 3 8}$ \\
\hline
\end{tabular}

Também foram identificados 38 gráficos que não estão inseridos na proposta inicial dessa análise, do tipo área, mas que representam valor inexpressivo em comparação à quantidade total de gráficos apresentada. Percebe-se que no ano de 1997 não foi utilizado por nenhuma emprega gráficos do tipo linha enquanto que no exercício de 2009 , foi empregada a maior quantidade de um mesmo tipo de gráfico num único relatório, referente à empresa Vulcabrás S.A que utilizou 69 gráficos do tipo coluna nesse ano. A empresa que mais empregou gráficos do tipo barra foi a São Paulo Alpargatas S/A, constituída em 1907 e que utilizou 31 gráficos nesse formato no relatório de 2010. Já a empresa que apresentou mais gráficos do tipo setorial foi a Randon S/A Implementos e Participações, que no exercício de 2008 empregou 21 gráficos em formato de setor (pizza ou rosca).

Foram encontrados um total de 5.202 gráficos com algum tipo de realce ou melhora de apresentação, o que corresponde a aproximadamente $68 \%$ do total de gráficos. O realce mais utilizado é a apresentação em três dimensões, tendo sido identificados 2.545 gráficos com essa ferramenta. Em seguida, foram identificados 1.334 gráficos reportando mais de 4 informações distintas, sendo 2010 o ano em que isso mais ocorreu, com um total de 155 gráficos com esse tipo de realce e também o ano com maior quantidade de gráficos com algum outro tipo de melhora, apresentando uma soma de 471 gráficos em 3D, com base maior que zero, linha e também excesso de informações. Estas características estão demonstradas na Tabela 11:

Tabela 11 - Gráficos com Realce ou Melhora de Apresentação

\begin{tabular}{cccccccccccccc}
\hline \multirow{2}{*}{ Ano } & \multicolumn{3}{c}{ 3D } & \multicolumn{4}{c}{ Base>0 } & \multicolumn{3}{c}{ Línha } & \multicolumn{3}{c}{$\begin{array}{c}\text { Excesso de } \\
\text { Informações }\end{array}$} \\
\cline { 2 - 13 } & Méd & Máx & Total & Méd & Máx & Total & Méd & Máx & Total & Méd & Máx & Total \\
\hline 1997 & 0,247 & 16 & 44 & 0,017 & 3 & 3 & 0,006 & 1 & 1 & 0,141 & 8 & 25 \\
1998 & 0,292 & 10 & 52 & 0,017 & 2 & 3 & 0,017 & 1 & 3 & 0,153 & 10 & 27 \\
1999 & 0,287 & 9 & 51 & 0,006 & 1 & 1 & 0,034 & 1 & 6 & 0,243 & 8 & 43 \\
2000 & 0,331 & 9 & 59 & 0,062 & 6 & 11 & 0,096 & 4 & 17 & 0,153 & 8 & 27
\end{tabular}




\begin{tabular}{ccccccccccccc}
2001 & 0,522 & 11 & 94 & 0,044 & 2 & 8 & 0,100 & 5 & 18 & 0,251 & 8 & 45 \\
2002 & 0,522 & 9 & 98 & 0,044 & 8 & 18 & 0,100 & 6 & 30 & 0,251 & 6 & 38 \\
2003 & 0,648 & 15 & 116 & 0,173 & 9 & 31 & 0,201 & 7 & 36 & 0,225 & 6 & 40 \\
2004 & 0,844 & 21 & 152 & 0,144 & 10 & 26 & 0,183 & 6 & 33 & 0,330 & 9 & 59 \\
2005 & 0,967 & 20 & 174 & 0,100 & 9 & 18 & 0,467 & 11 & 84 & 0,397 & 9 & 71 \\
2006 & 0,906 & 17 & 163 & 0,167 & 17 & 30 & 0,406 & 11 & 73 & 0,441 & 10 & 79 \\
2007 & 1,056 & 19 & 190 & 0,122 & 13 & 22 & 0,522 & 10 & 94 & 0,486 & 10 & 87 \\
2008 & 0,933 & 22 & 168 & 0,144 & 14 & 26 & 0,239 & 10 & 43 & 0,480 & 11 & 86 \\
2009 & 1,272 & 75 & 229 & 0,112 & 14 & 20 & 0,683 & 69 & 123 & 0,520 & 9 & 93 \\
2010 & 0,994 & 23 & 179 & 0,222 & 13 & 40 & 0,539 & 17 & 97 & 0,866 & 16 & 155 \\
2011 & 1,094 & 12 & 197 & 0,178 & 12 & 32 & 0,367 & 7 & 66 & 0,626 & 9 & 112 \\
2012 & 1,172 & 35 & 211 & 0,161 & 14 & 29 & 0,339 & 9 & 61 & 0,553 & 11 & 99 \\
2013 & 1,122 & 32 & 202 & 0,144 & 14 & 26 & 0,250 & 10 & 45 & 0,760 & 17 & 136 \\
2014 & 0,922 & 21 & 166 & 0,261 & 23 & 47 & 0,567 & 12 & 102 & 0,626 & 9 & 112 \\
\hline \multicolumn{1}{c}{ Total } & $\mathbf{2 5 4 5}$ & \multicolumn{1}{c}{ Total } & $\mathbf{3 9 1}$ & Total & $\mathbf{9 3 2}$ & Total & $\mathbf{1 3 3 4}$ \\
\hline
\end{tabular}

Observa-se também que o ano de 2007 foi o que apresentou maior quantidade de gráficos não só com realce, mas também de um único tipo deles com 190 gráficos em três dimensões. Esse também foi o tipo de realce que mais apareceu em único relatório, com 75 observações no relatório divulgado pela empresa Vulcabrás S/A em 2009. Já em 2014, a mesma empresa foi responsável por empregar a maior quantidade de gráficos de linhas em um mesmo ano, no total de 69 gráficos.

Os 7.669 dos 3.240 relatórios tiveram seu conteúdo analisado por títulos e eles foram classificados 9 categorias propostas na metodologia dessa pesquisa. É possível observar na Tabela 12 que a maioria dos gráficos, num total de 1.836 reportavam informações referentes às receitas das companhias enquanto a menor parte deles, apenas 274 traziam informações referentes a itens relacionados ao patrimônio dessas entidades. O total de gráficos que reportam resultados e receitas representam $42 \%$ do total de gráficos, a maioria portanto e consistente com estudos anteriores (BEATTIE; JONES, 1992; MATHER et al,1996; BEATTIE; JONES, 1999) que apontaram que as empresas empregam mais gráficos para reportar variáveis financeiraschave.

Tabela 12 - Conteúdos dos Relatórios

\begin{tabular}{ccccccccccccccccc}
\hline \multirow{2}{*}{ Ano } & \multicolumn{4}{c}{ Resultado } & \multicolumn{4}{c}{ Gastos } & \multicolumn{4}{c}{ Mercado } & \multicolumn{3}{c}{ Recursos } & \multicolumn{3}{c}{ Passivos } \\
\cline { 2 - 16 } & Méd & Máx & Total & Méd & Máx & Total & Méd & Máx & Total & Méd & Máx & Total & Méd & Máx & Total \\
\hline 1997 & 0,033 & 1 & 6 & 0,044 & 2 & 8 & 0,039 & 2 & 7 & 0,033 & 3 & 6 & 0,028 & 4 & 5 \\
1998 & 0,072 & 3 & 13 & 0,033 & 2 & 6 & 0,056 & 3 & 10 & 0,028 & 1 & 5 & 0,028 & 4 & 5 \\
1999 & 0,100 & 3 & 18 & 0,061 & 3 & 11 & 0,144 & 5 & 26 & 0,028 & 1 & 5 & 0,061 & 4 & 11 \\
2000 & 0,194 & 5 & 35 & 0,061 & 2 & 11 & 0,228 & 6 & 41 & 0,044 & 3 & 8 & 0,072 & 4 & 13 \\
2001 & 0,239 & 5 & 43 & 0,083 & 3 & 15 & 0,244 & 4 & 44 & 0,050 & 3 & 9 & 0,072 & 4 & 13 \\
2002 & 0,256 & 4 & 46 & 0,067 & 3 & 12 & 0,278 & 6 & 50 & 0,078 & 3 & 14 & 0,050 & 5 & 9
\end{tabular}




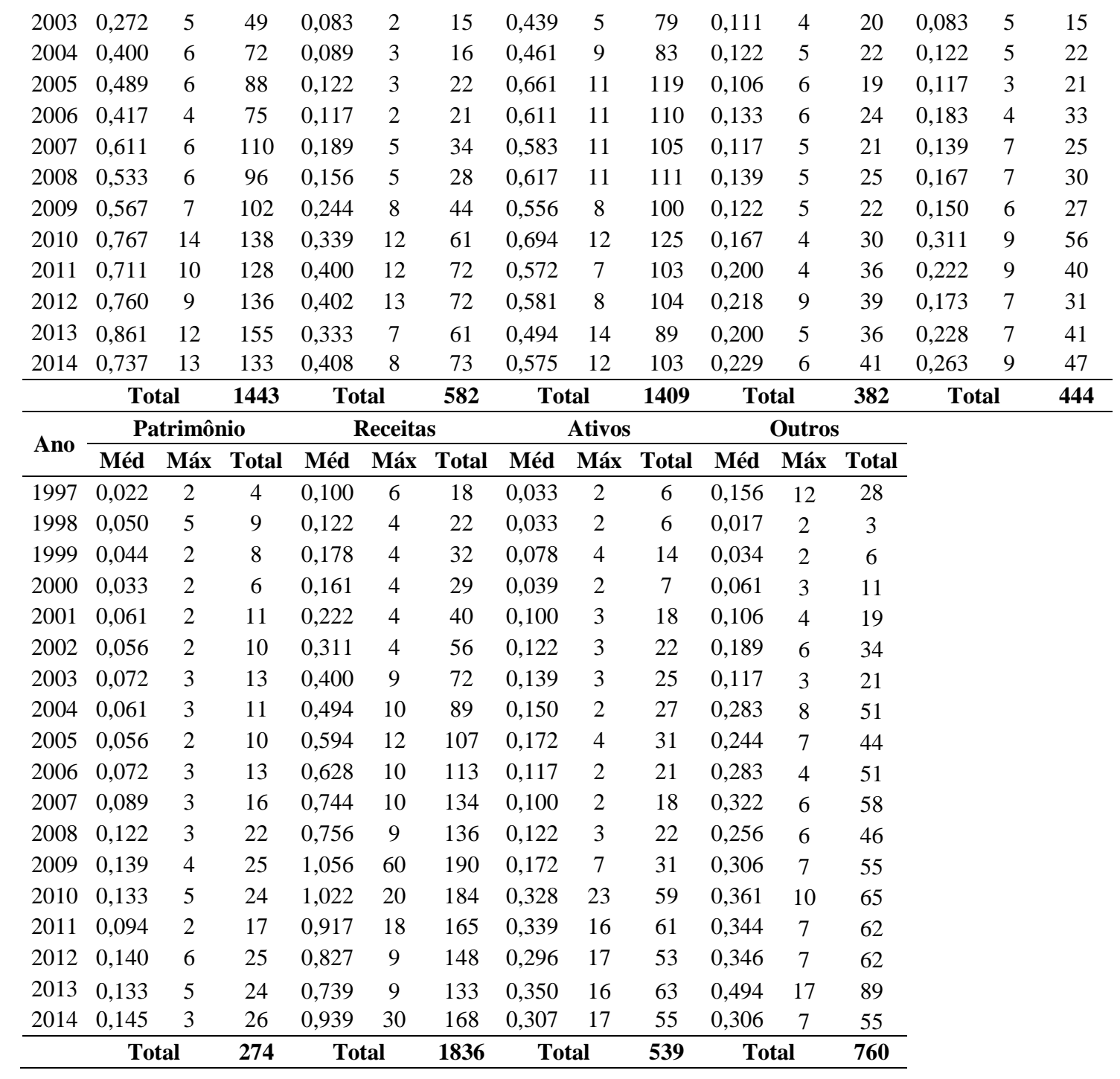

É possível perceber que, consistentemente com a evolução da quantidade de gráficos utilizada com o passar do tempo, cada categoria de conteúdo reportado também têm aumentado conforme os anos se passam, sendo possível verificar isso através das quantidades máximas de cada tipo de conteúdo no ano de 1997 e no ano de 2014. Na Tabela 13, também é possível verificar que conteúdos são reportados por gráficos em relação a cada categoria de setor de atuação:

Tabela 13 - Conteúdos dos Gráficos por Setor de Atuação

\begin{tabular}{|c|c|c|c|c|c|c|c|c|c|c|c|c|c|c|c|}
\hline \multirow{2}{*}{ Setor de Atuação } & \multicolumn{3}{|c|}{ Resultados } & \multicolumn{3}{|c|}{ Gastos } & \multicolumn{3}{|c|}{ Mercado } & \multicolumn{3}{|c|}{ Recursos } & \multicolumn{3}{|c|}{ Passivo } \\
\hline & Méd & Máx & Total & Méd & Máx & Total & Méd & Máx & Total & Méd & Máx & Total & Méd & Máx & Total \\
\hline Adm. e Participações & 0,273 & 12 & 226 & 0,134 & 13 & 111 & 0,277 & 14 & 229 & 0,053 & 4 & 44 & 0,097 & 4 & 80 \\
\hline Comércio & 0,855 & 14 & 354 & 0,240 & 8 & 100 & 0,391 & 9 & 160 & 0,143 & 4 & 59 & 0,135 & 5 & 56 \\
\hline $\begin{array}{l}\text { Construção e } \\
\text { Infraestrutura }\end{array}$ & 0,489 & 9 & 501 & 0,125 & 6 & 128 & 0,379 & 11 & 401 & 0,122 & 6 & 123 & 0,164 & 9 & 168 \\
\hline Financeiro & 0,160 & 2 & 49 & 0,056 & 3 & 22 & 0,310 & 8 & 95 & 0,248 & 9 & 76 & 0,000 & 0 & 0 \\
\hline Serviços & 0,122 & 2 & 22 & 0,128 & 5 & 26 & 0,067 & 3 & 12 & 0,100 & 3 & 17 & 0,000 & 0 & 0 \\
\hline
\end{tabular}




\begin{tabular}{|c|c|c|c|c|c|c|c|c|c|c|c|c|c|c|}
\hline Utilidade Pública & 0,648 & 8 & 291 & 0,434 & 4 & 195 & 1,140 & 12 & 512 & 0,134 & 3 & 63 & 0,312 & 140 \\
\hline & To & & 1443 & To & & 582 & To & & 1409 & To & & 382 & Total & 444 \\
\hline \multirow{2}{*}{ Setor de Atuação } & \multicolumn{3}{|c|}{ Patrimônio } & \multicolumn{3}{|c|}{ Ativos } & \multicolumn{3}{|c|}{ Receitas } & \multicolumn{3}{|c|}{ Outros } & & \\
\hline & Méd & Máx & Total & Méd & Máx & Total & Méd & Máx & Total & Méd & Máx & Total & & \\
\hline Adm. e Participações & 0 & 3 & 58 & 0,25 & 9 & 209 & 0,089 & 2 & 74 & 0,035 & 3 & 29 & & \\
\hline Comércio & 0 & 3 & 25 & 1,26 & 60 & 522 & 0,104 & 3 & 43 & 0,288 & 12 & 119 & & \\
\hline $\begin{array}{l}\text { Construção e } \\
\text { Infraestrutura }\end{array}$ & 0 & 6 & 76 & 0,72 & 12 & 744 & 0,190 & 23 & 194 & 0,180 & 11 & 186 & & \\
\hline Financeiro & 0,18 & 3 & 55 & 0,08 & 5 & 26 & 0,307 & 10 & 93 & 0,222 & 17 & 64 & & \\
\hline Serviços & 0,02 & 2 & 4 & 0,16 & 3 & 27 & 0,006 & 1 & 1 & 0,122 & 3 & 24 & & \\
\hline \multirow[t]{2}{*}{ Utilidade Pública } & 0 & 5 & 56 & 0,67 & 6 & 308 & 0,276 & 5 & 134 & 0,724 & 10 & 338 & & \\
\hline & \multicolumn{2}{|c|}{ Total } & 274 & \multicolumn{2}{|c|}{ Total } & 1836 & \multicolumn{2}{|c|}{ Total } & 539 & \multicolumn{2}{|c|}{ Total } & 760 & & \\
\hline
\end{tabular}

Foi possível verificar que dentre os conteúdos mais reportados, Resultados e Receitas, as empresas que mais empregam gráficos para informá-los são as dos setores inseridos nos grupos de Construção e Infraestrutura, seguidas pelas empresas de Comércio. A empresa Vulcabrás em 2009, da categoria de Comércio, foi a que mais empregou gráficos que reportassem um mesmo assunto: foram 60 gráficos diferentes para reportar informações relativas às receitas da companhia.

\subsection{Testes de Robustez}

A confirmação das hipóteses levantadas depende da relevância estatística apresentada pelas variáveis dependentes, no caso, a quantidade de gráficos. Assim, os testes empíricos para esta verificação foram realizados utilizando dados em painel (painel data), já que o conjunto de dados dessa pesquisa apresenta séries temporais (18 períodos - times series) e 180 elementos em corte transversal (crosssectional), num total de 3.240 observações.

Os modelos de estimação com dados em painel geralmente são feitos através de três abordagens: efeitos fixos, efeitos aleatórios e método pooled (dados agrupados). O método mais simples para lidar com os dados é através de uma regressão pooled, que envolve a estimação de uma única equação com todas as observações temporais juntas, empilhadas numa única coluna contendo todos os dados cross-sectional, sendo estimados pelo método tradicional de mínimos quadrados ordinários (MQO) (BROOKS, 2008). Este foi o método empregado nessa pesquisa, de onde pôde-se obter resultados considerados consistentes e confiáveis dado os cuidados tomados para ao atendimento das premissas necessárias para inferências. 
Há que se destacar que o objetivo dessa análise não é obter apenas os parâmetros, mas também realizar inferências estatísticas quanto a eles e à variável dependente. Nesse sentido, são estabelecidas premissas subjacentes a esse método para garantir a adequação dos resultados obtidos (GUJARATI, 2006). Uma dessas premissas, dada por var(ui) $=\sigma^{2}<\infty$, é que os termos de erro $u_{i}$ da função da regressão devem ser homocedásticos, ou seja, a variância dos erros deve ser constante. Quando essa premissa é violada, diz-se que o modelo apresenta problemas de heterocedasticidade.

Wooldridge (2002) pontua que a homocedasticidade é necessária para justificar os testes t, testes $\mathrm{F}$ e intervalos de confiança para estimação de modelos de regressão em mínimos quadrados ordinários, mesmo na presença de grandes amostras e Brooks (2008) afirma que se um modelo é estimado sem a correção desse problema, então assume-se a possibilidade de os erros padrões estarem incorretos e as inferências feitas a partir dos resultados obtidos serem enviesadas.

Outra premissa que deve ser observada segundo Brooks (2008) é que a covariância entre os termos de erro ao longo do tempo (ou de forma transversal, no caso de cross-section) deve ser zero. Em outras palavras, o termo de erro relacionado a qualquer das observações não pode ser influenciado pelo termo de erro de qualquer outra observação e caso isso não seja atendido, o modelo possui um problema de autocorrelação. Conforme apontamento de Gujarati (2006), assim como no caso da heterocedasticidade, os estimadores de MQO ainda são lineares, não tendenciosos, consistentes e com distribuição normal assintótica, mas deixam de ser eficientes. Isso porque mais uma vez, as inferências feitas através dos resultados serão enviesadas em face do risco de que na presença de autocorrelação, coeficientes podem ser insignificantes do ponto de vista estatístico (não diferente de zero) quando na verdade não seriam se tivessem sido estimados corretamente.

Para mitigar o risco desses problemas, as variáveis contábeis utilizadas no modelo foram escalonadas e empregou-se o método de erros padrões seccionais SUR - PSCE (Seemingly Unrelated Regression Panel Corrected Standard Errors). Segundo Wooldridge (2003), este método, gerará um estimador da matriz de variância-covariância consistente com a matriz de White, que corrige os desvios padrão quando há presença de heterocedasticidade, assim, o método de Zellner, como é conhecido, estima parâmetros para o sistema mesmo na presença de heterocedasticidade e ainda não presença de autocorrelação. (GUIDE, 2007). 
Outro conceito de extrema importância e desejável para interpretação dos dados estimados é a ideia de séries estacionárias, que são caracterizadas por apresentarem média, variância e auto-covariância constantes ao longo do tempo (BROOKS, 2008). Quando esse comportamento não ocorre, é provável a presença de raiz unitária e então o modelo enfrenta um problema de não-estacionariedade das séries. Novamente, as análises realizadas através de um modelo que apresente esse problema levaram a interpretações distorcidas, primeiramente porque essa pode ser uma das razões para a presença de autocorrelação e por conduzir à estimação de regressões espúrias (GUJARATI, 2006).

Regressões espúrias ocorrem quando não existe fundamento para que as variáveis y e x sejam relacionadas, mas a regressão de MQO utilizando as estatísticas t usuais indicou relação estatística (WOOLDRIGDE, 2003). Ou seja, é possível que a regressão de uma variável contra outra revele um $\mathrm{R}^{2}$ alto, ainda que essas duas variáveis sejam completamente independentes e que a relação não faça sentido (GUJARATI, 2006).

Para assegurar a robustez dos resultados obtidos e verificar se as séries possuíam raiz unitária, foram realizados os seguintes testes de robustez disponíveis no E-views: Levin, Li e Chu (LLC), Dickey-Fuller Aumentado (ADF) e Phillips -Perron (PP). Os testes foram feitos no painel, que são similares, mas não idênticos aos testes de raízes unitárias feitos em uma única série (FELLET, 2016). Ressalta-se que existe um consenso na literatura de que uso de testes de raiz unitária com modelo painel é uma forma de aumentar o poder dos testes de raiz unitário baseados em séries individuais e melhoram o poder estatístico dos testes de estacionariedade convencionais (MADDALA;WU,1999). Os resultados dos testes realizados podem ser observados na Tabela 14:

Tabela 14 - Testes de Raiz Unitária

\begin{tabular}{lcccccc}
\hline \multirow{2}{*}{ Modelo } & \multicolumn{2}{c}{ Levin, Li \& Chu } & \multicolumn{2}{c}{ ADF } & \multicolumn{2}{c}{ PP-Fisher } \\
\cline { 2 - 7 } & Estatística & p-valor & Estatística & p-valor & Estatística & p-valor \\
\hline KFV & -165.213 & 0,00 & 4927.04 & 0,00 & 6152.74 & 0,00 \\
GRMA & $-182,678$ & 0,00 & 31,150 & 0,00 & 3200,800 & 0,00 \\
\hline \multicolumn{3}{c}{ Fonte: Elaboração própria. }
\end{tabular}

Os resultados apontam se a hipótese nula da existência de raiz unitária pode ser corroborada ou não. Para os testes realizados, observando-se o resultado do p-valor para os dois modelos, verifica-se que todos foram inferiores a 0,05 , concorrendo para a rejeição da 
hipótese nula da existência de raiz unitária nos três testes realizados. Dessa forma, é possível estimar as regressões com a segurança de que as inferências não serão feitas em decorrência da estimação de regressões espúrias.

Mais uma premissa que deve ser observada é a normalidade dos resíduos, onde o termo estocástico (de erro) $\mathrm{u}_{i}$ deve estar distribuído normalmente. Gujarati (2006) afirma que essa premissa não é essencial se o objetivo for apenas a estimação, mas se o for validar as hipóteses através dos testes $t$ e $F$, então os estimadores de MQO dos coeficientes de regressão devem seguir a distribuição normal. Para assumir a normalidade dos resíduos, foi invocado o Teorema do Limite Central, onde a soma de variáveis aleatórias independentes, quando padronizadas pelos seus desvios-padrão, possuem uma distribuição que tende à normalidade à medida que a amostra aumenta (WOOLDRIDGE, 2003). Nesse sentido e com base nas 3.240 observações desse estudo, assumiu-se que os resíduos possuem distribuição normal e que em conjunto à verificação das demais premissas, é possível fazer inferências corretas dos modelos estimados.

Por fim, quando um modelo possui mais de uma variável explanatória, é necessário verificar a existência de multicolinearidade (GREENE, 2012). Segundo Gujarati (2006), esta é uma situação onde há uma relação linear exata ou aproximadamente exata entre as variáveis explanatórias e levam a coeficientes de regressão indeterminados e erros-padrão indefinidos ou muito grandes, que não permitem a estimação de coeficientes com precisão. Outro problema existente é em relação à significância do modelo, já que o $\mathrm{R}^{2}$ pode ser alto, mas os coeficientes individualmente, não serem significativos (BROOKS, 2008).

Para identificar a presença de multicolinearidade, Gujarati (2006) sugere que seja realizado o teste de inflação da variância entre as variáveis independentes do modelo, onde pode ser verificada a velocidade com que as variâncias e covariâncias aumentam. Em outras palavras, o Fator de Inflação de Variância (FIV) demonstra como a variância de um estimador é inflada pela presença de multicolinearidade e pode ser obtido através da seguinte equação:

$$
F I V=\frac{1}{1-R^{2}}
$$

Dessa forma, através do cálculo do coeficiente de correlação $\left(\mathrm{R}^{2}\right)$, foi obtido o fator de inflação da variância de cada uma das variáveis independentes para cada um dos dois modelos, conforme demonstrado nas Tabelas 15 e 16: 
Tabela 15 - Matriz de Correlação Modelo 1 -VFC

\begin{tabular}{|c|c|c|c|c|c|c|}
\hline & $V L$ & $R O A$ & TAMRA & LnI & $T 1$ & $T 3$ \\
\hline VL & - & & & & & \\
\hline ROA i,t & 1,1580541 & - & & & & \\
\hline TAMRA & 1,0084984 & 1,0555573 & - & & & \\
\hline LnI & 1,0385269 & 1,0970331 & 1,2227026 & - & & \\
\hline $\mathrm{T} 1$ & 1,0256761 & 1,0266061 & 1,250252 & 1,0021187 & - & \\
\hline $\mathrm{T} 3$ & 1,0045187 & 1,0144285 & 1,2343046 & 1,0010582 & 2 & - \\
\hline & $R O A$ & TAMRA & LnATIVO & $L n I$ & $T 1$ & $T 3$ \\
\hline ROA & - & & & & & \\
\hline TAMRA & 1,0555573 & - & & & & \\
\hline LnATIVO & 1,2133326 & 2,1712148 & - & & & \\
\hline LnI & 1,0970331 & 1,2227026 & 1,3648757 & - & & \\
\hline $\mathrm{T} 1$ & 1,0266061 & 1,250252 & 1,1154331 & 1,0021187 & - & \\
\hline $\mathrm{T} 3$ & 1,0144285 & 1,2343046 & 1,1409447 & 1,0010582 & 2 & - \\
\hline
\end{tabular}

Para a análise do FIV, foi levada em consideração a regra sugerida por Gujarati (2006) e Brooks (2008) de que se os resultados do FIV forem maiores do que 10, então a multicolinearidade é um problema para estimação dos parâmetros. Dessa forma, podem ser observadas em ambas as tabelas, que nenhuma das variáveis desse estudo apresentou valores indicativos de colinearidade entre elas.

\subsection{Resultados da Significância dos Modelos e Hipóteses de Pesquisa}

Consistentemente aos estudos realizados anteriormente (BEATTIE; JONES, 1992; 1997; MATHER et al, 1996), a primeira hipótese desta pesquisa foi testada com o auxílio do teste não-paramétrico qui-quadrado de Pearson (Teste $\chi^{2}$ ) que, testa se duas variáveis são independentes. Foi então realizado o teste do qui-quadrado para os relatórios que apresentaram gráficos versus os que não apresentaram em relação ao resultado financeiro reportado (lucro ou prejuízo) resumidos na Tabela 17:

\begin{tabular}{cccc}
\multicolumn{4}{c}{ Tabela 17 - Resumo Relatórios Gráficos x Desempenho } \\
\hline RELATÓRIOS & LUCRO & PREJUÍZO & TOTAL \\
\hline COM GRÁFICO & 808 & 248 & 1056 \\
SEM GRÁFICO & 1403 & 781 & 2184 \\
\hline \multicolumn{1}{c}{ TOTAL } & $\mathbf{2 2 1 1}$ & $\mathbf{1 0 2 9}$ & $\mathbf{3 2 4 0}$ \\
\hline
\end{tabular}


Admitindo-se um nível de significância de 5\%, para 1 grau de liberdade, o valor do $\chi^{2}$ deve ser superior a 3,841 para que o resultado seja estatisticamente relevante. Para os dados dessa pesquisa, encontrou-se o valor de 49,49, acima do valor crítico, sendo rejeitada, portanto, a hipótese nula de que não há associação entre os grupos testados. Dessa forma, a hipótese 1 de que existe associação estatística significativa entre a quantidade de gráficos empregada e o desempenho financeiro das empresas não pode ser rejeitada e corrobora os resultados encontrados por Beattie e Jones (1992; 1997; 2000a).

Para testar as demais hipóteses do estudo, foram realizadas duas regressões relacionando as variáveis independentes (lucratividade, variação no resultado, tamanho da empresa, idade da empresa, tamanho do relatório, e passagem do tempo) com as variáveis dependentes VFC gráficos sobre variáveis financeiras-chave e GRMA - gráficos com realce ou melhora apresentação.

Assim, os resultados dos testes empíricos com o uso de dados em painel (método pooled de dados agrupados) e a utilização das VFC como indicativo de gerenciamento de impressão estão apresentados na Tabela 18, para verificação das Hipóteses 2 e 3 :

Tabela 18 - Resultados da Regressão das Hipóteses 2 e 3

\begin{tabular}{|c|c|c|}
\hline \multicolumn{3}{|c|}{ Modelo Testado } \\
\hline \multicolumn{3}{|c|}{$V F C_{i_{j} t}=\alpha+\beta_{1} R O A_{i, t}+\beta_{2} V R_{i_{s} t}+\beta_{3} L N I+\beta_{4} T A M R A_{i_{i} t}+\beta_{5} T_{1}+\beta_{6} T_{3}+\varepsilon$} \\
\hline Variáveis & Coeficientes & p-valor \\
\hline $\mathbf{C}$ & -0.250783 & 0.0349 \\
\hline ROA & 0.001334 & 0.0463 \\
\hline VR & $7.14 \mathrm{E}-05$ & 0.7000 \\
\hline LNI & 0.097560 & 0.0016 \\
\hline TAMR & $5.08 \mathrm{E}-05$ & 0.0000 \\
\hline T1 & -0.072530 & 0.0084 \\
\hline T3 & 0.144273 & 0.0000 \\
\hline $\mathbf{R}^{2}$ & & 0.043015 \\
\hline $\mathbf{R}^{2}$ Ajustado & & 0.041113 \\
\hline DW & & 0.565067 \\
\hline Estatística F & & 22.61663 \\
\hline P-Valor (F) & & 0.000001 \\
\hline
\end{tabular}

Para a segunda hipótese de que existe relação estatística entre a utilização de gráficos que reportam variáveis financeiras-chave (lucro, receita líquida e dividendos) e o desempenho financeiro, observou-se o resultado para a variável ROA, proxy para lucratividade, tendo as 
demais variáveis independentes empregadas como variáveis de controle. Foi observada significância estatística para esta variável, sustentada pela estatística $\mathrm{F}$, com p-valor de 0,000001. Portanto, os resultados concorrem para a não rejeição da hipótese 2 , corroborando os achados obtidos por Beattie e Jones (1992; 1999; 2000a) e Cho et al (2016). Já para a variável VR, indicativa da variação no resultado de um ano para o outro, não foi observada relação estatística significativa. Dessa forma, rejeita-se a hipótese 3 de que existe relação entre a quantidade de gráficos relativos a VFC e mudança de situação financeira.

Para a análise da hipótese 4, que verifica se existe relação entre a utilização de gráficos com realce ou melhora de apresentação e o tamanho da empresa, foram obtidos os resultados através da regressão demonstrada na Tabela 19, novamente com o emprego das demais variáveis independentes testadas como variáveis de controle:

Tabela 19 - Resultados da Regressão da Hipótese 4

\begin{tabular}{lrr}
\hline \multicolumn{3}{c}{ Modelo Testado } \\
\hline \multicolumn{1}{c}{ GRMA $_{i, t}=\alpha+\beta_{1} R O A_{i, t}+\beta_{2} L N A T I V O_{i, t}+\beta_{3} L N I+\beta_{4} T_{A M R A_{i, t}}+\beta_{5} T_{1}+\beta_{6} T_{3}+\varepsilon$} \\
\hline \multicolumn{1}{c}{ Variáveis } & Coeficientes & p-valor \\
\hline C & -0.127408 & 0.0052 \\
LNATIVO & 0.012229 & 0.0001 \\
ROA & 0.000913 & 0.1069 \\
LNI & 0.037761 & 0.0000 \\
TAMR & $3.39 \mathrm{E}-05$ & 0.0000 \\
T1 & -0.083108 & 0.0000 \\
T3 & 0.007488 & 0.7052 \\
\hline $\mathbf{R}^{2}$ & & 0.110496 \\
$\mathbf{R}^{2}$ Ajustado & & 0.108845 \\
DW & & 0.645074 \\
Estatística F & & 66.93468 \\
P-Valor (F) & & 0.000000 \\
\hline
\end{tabular}

Observa-se que a variável LNATIVO apresentou significância para a quantidade de gráficos melhorados, proxy para o gerenciamento de impressão. No entanto, esperava-se que essa relação fosse negativa, dado que conforme sustentação das hipóteses, empresas de maior porte apresentam melhores níveis de evidenciação, logo empregariam menos gráficos distorcidos. Nesse sentido, os resultados encontrados indicam que a quantidade de gráficos que violam algum princípio de construção gráfica, está positivamente relacionada ao tamanho da empresa, concorrendo para a rejeição da hipótese 4. 
No que se refere às variáveis de controle não representativas de gerenciamento de impressão, acrescentadas aos modelos para aprimorar as evidências empíricas encontradas, foi possível observar nos dois modelos que as variáveis LNI e TAMRA apresentaram relação estatística significativa de modo que quanto mais antiga a empresa e maior o tamanho do relatório, mais gráficos sobre variáveis financeiras-chave e gráficos com realce são empregados nos relatórios da administração. Essas relações eram esperadas para o primeiro modelo, no entanto a relação positiva entre a idade da empresa e a variável GRMA no segundo modelo foi de encontro com o que a teoria previa de que empresas com mais tempo de constituição tendem a ter práticas de divulgação mais desenvolvidas em função da necessidade de preservar sua imagem junto ao mercado (AKHTARUDDIN, 2005).

A variável empregada como medida de lucratividade ROA, no segundo modelo, não apresentou relação estatística significativa. Isso significa que o desempenho financeiro da empresa não explica ou não influencia a utilização de gráficos visualmente distorcidos. Quanto as variáveis T1 e T3, relativas ao período de tempo no qual os relatórios foram publicados, verifica-se relação para VFC de T3 e relação inversa de T1, indicando que no primeiro período as empresas divulgavam menos gráficos reportando lucro, receitas e dividendos, e que houve um aumento da utilização desses gráficos nos anos mais recentes. Para o modelo que testou a relação com GRMA, foi observada novamente relação inversa para T1 e nenhuma relação significativa para T3, ou seja, os relatórios publicados de 1997 a 2002 empregavam menos gráficos com melhora ou realce de apresentação, mas não existe relação entre a quantidade empregada desses gráficos e os anos mais recentes.

$\mathrm{Na}$ Tabela 20, é possível verificar um resumo dos comportamentos esperados e observados das variáveis independentes em relação às variáveis VFC e GRMA, levando em consideração que a variável LNATIVO não foi testada para o primeiro modelo e nem a variável VR para o segundo, portanto as observações para essas duas variáveis não se aplicam e que apenas as variáveis com relação significativa foram sinalizadas. 
Tabela 20 - Resumo dos Sinais Encontrados

\begin{tabular}{l|cc|cc}
\hline \multirow{2}{*}{ Variáveis } & \multicolumn{3}{|c|}{ VFC } & \multicolumn{2}{c}{ GRMA } \\
\cline { 2 - 6 } & Esperado & Observado & Esperado & Observado \\
\hline LNATIVO & NA & NA & - & + \\
ROA & + & + & + & \\
VR & + & & NA & NA \\
LNI & + & + & - & + \\
TAMR & + & + & + & + \\
T1 & - & - & - & - \\
T3 & + & + & + & \\
\hline
\end{tabular}

Por fim, o Quadro 4 apresenta o resumo dos resultados das hipóteses levantadas no estudo:

Quadro 4 - Resultados das Hipóteses da Pesquisa

\begin{tabular}{|c|c|c|}
\hline \multicolumn{2}{|r|}{ Hipóteses } & Resultados \\
\hline $\begin{array}{l}\text { Hipótese } \\
\text { 1: }\end{array}$ & $\begin{array}{l}\text { Existe associação estatística significativa entre a quantidade de gráficos e o } \\
\text { desempenho financeiro da empresa. }\end{array}$ & Corroborada \\
\hline $\begin{array}{l}\text { Hipótese } \\
\text { 2: }\end{array}$ & $\begin{array}{l}\text { Existe associação estatística significativa entre a quantidade de gráficos que } \\
\text { reportam variáveis financeiras chaves (lucro líquido, receita líquida e } \\
\text { dividendos) e o desempenho financeiro da empresa. }\end{array}$ & Corroborada \\
\hline $\begin{array}{l}\text { Hipótese } \\
\text { 3: }\end{array}$ & $\begin{array}{l}\text { Existe associação estatística entre a quantidade de gráficos que reportam } \\
\text { variáveis financeiras chaves e mudanças de situação no desempenho } \\
\text { financeiro da empresa. }\end{array}$ & Refutada \\
\hline $\begin{array}{l}\text { Hipótese } \\
\text { 4: }\end{array}$ & $\begin{array}{l}\text { Existe associação estatística negativa entre o tamanho da empresa e a } \\
\text { quantidade de gráficos com realce ou melhora de apresentação empregados } \\
\text { nos RAs. }\end{array}$ & Refutada \\
\hline
\end{tabular}

Os resultados apresentados demonstram que as hipóteses 1 e 2 foram corroboradas enquanto as hipóteses 3 e 4 foram refutadas, revelando evidências de gerenciamento de impressão nos relatórios da administração divulgados por companhias abertas brasileiras na forma de seletividade gráfica e melhora de apresentação. 


\section{CONSIDERAÇÕES FINAIS}

O objetivo dessa pesquisa foi verificar quais as evidências de gerenciamento de impressão nos gráficos empregados nos Relatórios da Administração divulgados por companhias abertas brasileiras no período de 1997 a 2014. A questão de pesquisa foi devidamente respondida através da análise dos RAs de 180 empresas que atenderam aos critérios estabelecidos para seleção da amostra através da técnica de análise de conteúdo. Também foram estabelecidos os parâmetros para identificação do gerenciamento de impressão nas formas de seletividade gráfica e melhora de apresentação, além da avaliação das seguintes variáveis através de regressões agrupadas (pooled): tamanho da empresa, lucratividade, variação no resultado financeiro, idade da empresa, tamanho dos relatórios e período de publicação.

Os principais resultados encontrados quanto ao emprego de recursos visuais indicaram que a maior parte dos relatórios divulgados no período de análise não empregaram qualquer tipo de recurso gráfico, e que as tabelas são o principal recurso visual utilizado para reportar informações financeiras, representando mais da metade dos 16.936 gráficos, tabelas ilustrações e fotos levantados.

Foram encontrados 7.669 gráficos, sendo a maioria deles do tipo Coluna, seguido pelos gráficos de barra, depois setorial e em último gráficos do tipo linha. Verificou-se que a maior parte dos gráficos apresentavam algum tipo de realce ou melhora de apresentação, sendo o emprego de três dimensões o mais encontrado. Quanto à análise de conteúdo, constatou-se que o conteúdo mais reportado graficamente é relacionado às receitas das companhias, o que também foi apontado pelos resultados encontrados por Beattie e Jones (1992; 1999) e Mather et al (1996), enquanto as informações relativas ao Patrimônio Líquido foram as menos destacadas.

Investigou-se ainda quatro hipóteses a fim de verificar se existem indícios de gerenciamento de impressão nos relatórios analisados. As três primeiras hipóteses referiram-se ao gerenciamento de impressão através da seletividade gráfica. Foram estabelecidos como parâmetros de seletividade a escolha de empregar ou não recursos gráficos, bem como a inclusão de gráficos que reportassem variáveis financeiras consideradas chaves na literatura 
acerca de gráficos em relatórios financeiros (lucro líquido, receita líquida e dividendos) e o desempenho financeiro reportado.

Os resultados demonstraram que existe relação significativa entre a quantidade total de gráficos e também a quantidade de gráficos sobre VFC e o resultado reportado através da não rejeição das hipóteses 1 e 2. Esses resultados estão em conformidade com o que foi encontrado em pesquisas anteriores sobre o assunto com hipóteses semelhantes (BEATTIE; JONES, 1992, 1999, 2000a; CHO et al, 2016). No entanto, não foi observada relação entre mudanças no desempenho de um período para o outro, observadas através de uma diminuição ou aumento no resultado líquido, e a quantidade de gráficos sobre VFC, resultado esse diferente do que foi encontrado por Steinbart (1989) e resultando na rejeição da hipótese 3.

A segunda análise realizada faz referência à melhora ou realce de apresentação em recursos gráficos, indicativos de gerenciamento de impressão e investigados nesse estudo através do emprego de gráficos em três dimensões, base maior que zero, linhas indicativas de múltiplas escalas e excesso de informações gráficas. Como resultado da hipótese 4 , esperavase que não houvesse relação significativa entre a variável dependente GRMA e o tamanho da empresa, ou seja, esperava-se que empresas de maior porte não apresentassem gerenciamento de impressão na forma de melhora ou realce de apresentação gráfica. No entanto, os resultados encontrados concorreram para a rejeição dessa hipótese.

Foi constatada ainda relação significativa entre as variáveis dependentes empregadas como medidas da quantidade de gráficos (VFC e GRMA) e as variáveis independentes referentes à idade e tamanho dos relatórios. No entanto, esse resultado não era esperado para o segundo modelo que revelou que empresas mais antigas têm empregado mais gráficos distorcidos. Também não foi encontrada relação entre a quantidade de gráficos com distorções e o desempenho financeiro das empresas. Com base na estatística das variáveis referentes ao período de publicação, verificou-se que de 1997 a 2002, as empresas empregavam menos gráficos sobre variáveis financeiras-chaveou com alguma distorção de apresentação. No entanto, não foi encontrada relação estatística entre a quantidade de GRMA empregados e os anos mais recentes. 


\subsection{Contribuições, Limitações e Sugestões para Pesquisas Futuras}

Em termos gerais, os achados dessa pesquisa indicam que os recursos gráficos, apesar de extensamente utilizados nos relatórios da administração divulgados por companhias brasileiras, não estão sendo empregados unicamente de forma altruística para facilitar a comunicação de informações financeiras. As evidências encontradas quanto à seletividade e melhora de apresentação gráfica, sinalizam que esses recursos podem estar sendo usados como ferramenta de gerenciamento de impressão. Dessa forma, os resultados desse estudo contribuem inicialmente para os praticantes do mercado sinalizando a falta de neutralidade dos relatórios da administração que é reconhecida como um elemento essencial da divulgação de informações financeiras (BEATTIE; JONES, 1992).

Adicionalmente, os achados de pesquisas experimentais indicam que a percepção do usuário é consideravelmente afetada pela presença de infidelidades gráficas. Assim, devido à extensão da utilização de gráficos nos relatórios analisados, os resultados desse estudo apontam a necessidade de que sejam desenvolvidas orientações específicas tanto para os preparadores dos relatórios, quanto para os auditores e CVM, órgão regulador no Brasil, que permitam a identificação de gráficos que estejam reportando informações de maneira enviesada e afetando o grau de utilidade e confiabilidade dos relatórios.

Além disso, esta pesquisa traz algumas contribuições à comunidade acadêmica primeiramente por investigar a utilização de gráficos em relatórios de companhias abertas do mercado acionário de um país não desenvolvido, demanda que já foi apontada em pesquisas anteriores (BEATTIE; JONES, 2008) e permitirá que estudos futuros sejam realizados no sentido de verificar possíveis diferenças no que diz respeito às práticas gerenciais que influenciam os padrões de evidenciação em culturas distintas. Esta pesquisa também abordou de maneira mais aprofundada a questão da melhora de apresentação, um dos três aspectos de infidelidade gráfica, mas que é menos explorado que os outros na academia. E principalmente, ela aprofunda a discussão sobre a extensão da utilização de gráficos como ferramenta de evidenciação e suas implicações na literatura existente no país, que é notadamente escassa quanto ao assunto e traz ainda uma abordagem empírica pouco empregada nas pesquisas realizadas até o momento. 
Quanto às limitações, esse estudo apresenta algumas, inicialmente, em relação à metodologia. Primeiramente, a análise de conteúdo é subjetiva, ou seja, ao agrupar os vários conteúdos reportados pelos gráficos em categorias para facilitar a análise, incorre-se no risco de que elas não reflitam as categorias da mesma maneira. Além disso, os resultados obtidos estão limitados às empresas selecionadas para amostra, não sendo possível fazer generalizações. Outro ponto que deve ser ressaltado é que apesar dos resultados sinalizarem a possibilidade de gerenciamento de impressão, há que se levar em consideração a chance de que as evidências encontradas não sejam em decorrência da intencionalidade, mas do despreparo ou falta de atenção de quem elabora os relatórios (BEATTIE;JONES, 2008), investigação que não foi abrangida pelo escopo dessa pesquisa.

Para pesquisas futuras, sugere-se que novas hipóteses sejam levantadas para testar padrões de gerenciamento de impressão através de recursos gráficos e a inclusão de outras variáveis no modelo para verificar se características como setor de atuação e qualidade de auditoria, por exemplo, possuem algum impacto sobre a forma como os gráficos financeiros são construídos. Sugere-se ainda que as distorções físicas dos gráficos, outro aspecto de infidelidade gráfica, sejam investigadas para a amostra desta pesquisa devidamente ajustada ao horizonte temporal.

Por fim, como já vem sendo investigado em pesquisas estrangeiras, sugere-se que novos estudos comparativos sobre a utilização de gráficos em relatórios financeiros sejam realizados em relação ao mercado brasileiro. Uma possibilidade interessante está na investigação das diferenças entre o emprego de gráficos num mercado como o brasileiro, onde ainda não há regulação específica sobre o assunto, e a utilização desses recursos em países como o Canadá, que já apresentam orientações para elaboração e divulgação de informações gráficas (Rahman et al, 2014). 


\section{REFERÊNCIAS}

AECA, XV Encuentro. Do uso de gráficos no relato financeiro: princípios, distorsões e evidências. XV Encuentro AECA, p. 24, 2012.

AKERLOF, George. A. The Market for 'Lemons': quality uncertainty and the market mechanism. The Quarterly Journal of Economics, v. 84, n. 3, p. 488-500, 1970.

AKHTARUDDIN, Md. Corporate mandatory disclosure practices in Bangladesh. The InternationalJournalofAccounting, v. 40, n. 4, p. 399-422, 2005

ALMEIDA, Paulo de Souza Soares de. A divulgação de informações voluntárias em relatórios anuais de companhias abertas. Rio de Janeiro, 1988. Dissertação (Mestrado em Ciências Contábeis) - Instituto Superior de Estudos Contábeis da Fundação Getúlio Vargas (ISEC/FGV).

ALOTAIBI, KhaleedOmair; HUSSAINEY, Khaled. Quantity versus Quality: The Value Relevance of CSR Disclosure of Saudi Companies. Corporate Ownership and Control, v. 13, n. 2, 2016.

ANGONESE, Rodrigo; GRZYBOVSKI, Denize; MOZZATO, AneliseRebelato. Determinantes Do Nível De Evidenciação De Informações Voluntárias: Estudo Em Empresas Com Ações

Negociadas Na Bm\&Fbovespa. Revista de Gestão do Unilasalle, v. 3, n. 2, p. p. 93-110, 2014.

ARAÚJO NETO, Pedro Lopes de; MORAES JUNIOR, Valdério Freire de ; BRASIL, A. M. S. . Evidenciação dos Demonstrativos em Entidades Sindicais: Caso dos Auditores Fiscais do Estado do Rio Grande do Norte. In: XVIII CONGRESSO BRASILEIRO DE CONTABILIDADE, 2008, Gramado. Anais do Congresso Brasileiro de Contabilidade, 2008.

BEATTIE, V.; JONES, M. J. The Use and Abuse of Graphs in Annual Reports: Theoretical Framework and Empirical Study. Accounting and Business Research. v. 22, n. 88, p. 291-303, 1992.

An empirical study of graphical format choices in charity annual reports. Financial Accountability and Management, v. 10, n. 3, p. 215-236, 1994.

A Comparative Study of the Use of Financial Graphs in the Corporate Annual Reports of Major U.S. and U.K. Companies. Journal of International Financial Management Accounting, v. 8, n. 1, p. 33-68, 1997.

. Graphical Reporting Choices: Communication or Manipulation?, Research Report 56, Chartered Association of Certified Accountants, Certified Accountants Educational Trust, 1998.

“Australian Financial Graphs: An Empirical Study” ABACUS 35(1): 46-76, 1999.

.Impression Management: the case of inter-country financial graphics. Journal of

International Accounting, Auditing \& Taxation. v. 9, n. 2, p. 159- 183, 2000a. 
Changing graph use in corporate annual reports: A time-series analysis. Contemporary Accounting Research. 17 (2): 213-226, 2000 b.

. Measurement distortion of graphs in Corporate Reports: an experimental study.

Accounting, Auditing \& Accountability Journal. Vol. 15.n. ${ }^{\circ}$ 4. pp. 546-564. 2002.

. Corporate Reporting Using Graphs: A Review and Synthesis, Journal of Accounting Literature, v. 27, p. 71-110, 2008a

. Investigating Presentational Change in UK Annual Reports A Longitudinal

Perspective.Journal of Business Communication, v. 45, n. 2, p. 181-222, 2008 b.

BEUREN, Ilse Maria. Divulgação de informações voluntárias em relatórios financeiros e seu relacionamento com a estrutura das empresas e características dos contabilistas. Rio de Janeiro,1991. Dissertação (Mestrado em Ciências Contábeis) - Instituto Superior de Estudos Contábeis da Fundação Getúlio Vargas. (ISEC/FGV).

BEUREN, I. M. ; GALLON, Alessandra Vasconcelos . Análise de conteúdo dos itens obrigatórios ou recomendados e de divulgação espontânea no relatório da administração das companhias abertas.Revista de Educação e Pesquisa em Contabilidade - REPeC, v. 4, p. 1$15,2008$.

BHANA, N.The chairman's statements and annual reports: Are they reporting the same company performance to investor?. Investment Analysts Journal, 70, 2009.

BINI, Laura; GIUNTA, Francesco; DAINELLI, Francesco. Signalling Theory and Voluntary Disclosure to the Financial Market-Evidence from the Profitability Indicators Published in the Annual Report. Availableat SSRN 1930177, 2010.

BLAKE, John; GUTIÉRREZ, Soledad Moya; SALAS, José OriolAmat. La contabilidadcreativaenEspaña y enel Reino Unido: Unestudio comparativo. In: VII Encuentro de profesoresuniversitarios de contabilidad: Barcelona, Centro de EstudiosFinancieros, p. 525-540, 1996.

BOUDT, Kris; THEWISSEN, James. Jockeying for Position in CEO Letters: Impression Management and Sentiment Analytics. Available at SSRN 2326400, 2015.

BRAGINSKY, B. M.; BRAGINSKY, D. D. Schizophrenic patients in the psychiatric interview: an experimental study of their effectiveness at manipulation. Journalof Consulting Psychology, v. 31, n. 6, p. 543-547, dez 1967.

BRAMMER, Stephen; PAVELIN, Stephen. Factors influencing the quality of corporate environmental disclosure. Business Strategy and the Environment, v. 17, n. 2, p. 120-136, 2008.

BRASIL. Lei 6.404, de 15 de dezembro de 1976. Dispõe sobre as Sociedades por Ações. Diário Oficial da União em 17.12.77. Disponível em <www.planalto.gov.br/>. Acesso em: 30 de abril de 2014. 
BRENNAN, Niamh M.; GUILLAMON SAORIN, Encarna; PIERCE, Aileen. Impression management: developing and illustrating a scheme of analysis for narrative disclosures-a methodological note. Accounting, Auditing and Accountability Journal, v. 22, n. 5, p. 789832, 2009.

BROOKS, C. Introductoryeconometrics for finance. Cambridge Universitypress, 2008 BURGESS, D. O., DILLA, W. N., STEINBART, P. J., \& SHANK, T. M. Does graph design matter to CPAs and financial statement readers?. Journal of Business \& Economics Research (JBER), v. 6, n. 5, 2008.

CHATTERJEE, B., TOOLEY, S., FATSEAS, V., \& Brown, A. An analysis of the qualitative characteristics of management commentary reporting by New Zealand companies.Australasian Accounting, Business and Finance Journal, v. 5, n. 4, p. 43-64, 2012.

CHO, Charles H.; MICHELON, Giovanna; PATTEN, Dennis M. Impression management in sustainability reports: An empirical investigation of the use of graphs.Accounting and the Public Interest, v. 12, n. 1, p. 16-37, 2012.

CHOI, Frederick DS. Financial disclosure and entry to the European capital market. Journalofaccountingresearch, p. 159-175, 1973.

CHOW, Chee W.; WONG-BOREN, Adrian. Voluntary financial disclosure by Mexican corporations. Accountingreview, p. 533-541, 1987.

CLEVELAND, William S.; MCGILL, Robert. An experiment in graphical perception. InternationalJournalof Man-MachineStudies, v. 25, n. 5, p. 491-500, 1986.

COMISSÃO DE VALORES MOBILIÁRIOS. Parecer de Orientação CVM nº 15, de 28 de Dezembro de 1987. Disponível em < http://www.cvm.gov.br >. Acesso em: 27 de abril de 2014.

CORMIER, Denis; LEDOUX, Marie-Josée; MAGNAN, Michel. The informational contribution of social and environmental disclosures for investors. Management Decision, v. 49, n. 8, p. 1276-1304, 2011.

CUNHA, R. K. C. ; SILVA, C. A. T. . Análise Da Facilidade De Leitura Das Demonstrações Contábeis Das Empresas Brasileiras: Uma Investigação Do Gerenciamento De Impressões Nas Narrativas Contábeis. In: $9^{\circ}$ Congresso USP de Controladoria e Contabilidade, 2009, São Paulo. $9^{\circ}$ Congresso USP de Controladoria e Contabilidade, 2009.

DAGILIENE, Lina. The research of corporate social responsibility disclosures in annual reports. Engineering Economics, v. 21, n. 2, 2015.

DALMÁCIO, Flávia Zóboli ; PAULO, Francislene Ferraz Magalhães de . A Evidenciação Contábil: Publicação de Aspectos Sócio-ambientais e Econômico-Financeiros nas Demonstrações Contábeis. BBR. Brazilian Business Review, Vitória, v. 1, n.2, p. 73-88, 2004.

DANTAS, José Alves. Auditoria em Instituições Financeiras: determinantes de qualidade no mercado brasileiro. Brasília, 2012. 191 p. Tese (Doutorado em Ciências Contábeis) Programa Multiinstitucional e Inter-regional de Pós-graduação em Ciências Contábeis das 
Universidades de Brasília, Universidade Federal da Paraíba e Universidade Federal do Rio Grande do Norte.

DANTAS, José Alves ; ZENDERSKY, Humberto Carlos ; NIYAMA, Jorge Katsumi . A dualidade entre os benefícios do disclosure e a relutância das organizações em aumentar o grau de evidenciação. In: X Semana de Contabilidade do Banco Central - DF, 2004, Brasília, 2004.

DEMO, Pedro. Metodologia científica em ciências sociais. 3. ed. São Paulo: Atlas, 1995. DIAMOND, Douglas W.; VERRECCHIA, Robert E. Disclosure, liquidity, and the cost of capital. The journal of Finance, v. 46, n. 4, p. 1325-1359, 1991.

DIAS FILHO, José Maria; NAKAGAWA, Masayuki. Análise do Processo da Comunicação Contábil: Uma contribuição para a solução de problemas semânticos, utilizando conceitos da Teoria da Comunicação. Revista Contabilidade \& Finanças, FIPECAFI - FEA - USP, São Paulo, FIPECAFI, v.15, n. ${ }^{\circ}$ 26, p. 42 - 57, maio/agosto 2001.

DILLA, William N.; JANVRIN, Diane J. Voluntary disclosure in annual reports: the association between magnitude and direction of change in corporate financial performance and graph use. Accounting Horizons, v. 24, n. 2, p. 257-278, 2010.

DONÁ, A. L.;MARQUES, K. C. M.;MORIBE, A. M.; JUNIOR, J. B. H. Fatores Determinantes Do Conteúdo Divulgado No Relatório De Administração De Empresas Brasileiras.

RevistaUniversoContábil, v. 11, n. 4, p. 82-106, 2016.

DYE, Ronald A. Anevaluationof "essaysondisclosure" andthedisclosureliterature in accounting. JournalofAccountingandEconomics, v. 32, n. 1, p. 181-235, 2001.

EISENHARDT, Kathleen M. Agency theory: An assessment and review. Academy of management review, v. 14, n. 1, p. 57-74, 1989.

FELLET, Bianca Gabriel.Avaliação de modelos de precificação de ativos no mercado acionário brasileiro. Dissertação (Mestrado em Ciências Contábeis) Brasília, 2016. Universidade de Brasília, Programa Multiinstitucional e Inter0Regional de Pós-Graduação.Ano de obtenção: 2016.

FERCHICHI, Jihene; PATUREL, Robert. The effect of intellectual capital disclosure on the value creation: An empirical study using Tunisian annual reports. International Journal of Accounting and Financial Reporting, v. 3, n. 1, p. 81, 2013.

FERREIRA, Leonor. Graph Usage in Financial Reports. TeseDoutorado. NOVA-School of Business and Economics, Portugal, 2015.

FREEMAN, R. Edward; WICKS, Andrew C.; PARMAR, Bidhan. Stakeholder theory and "the corporate objective revisited”. Organization science, v. 15, n. 3, p. 364-369, 2004.

FRINK, Dwight D.; FERRIS, Gerald R. Accountability, impression management, and goal setting in the performance evaluation process.Human relations, v. 51, n. 10, p. 1259-1283, 1998. 
GALANI, Despina; ALEXANDRIDIS, Anastasios; STAVROPOULOS, Antonios. The association between the firm characteristics and corporate mandatory disclosure the case of Greece. World Academy of Science, Engineering and Technology, v. 77, p. 101-107, 2011.

GHANBARI, Mehrdad; ASADOLLAHI, SeyyedYahya; TAHERI, Fatemeh. Determining the Relationship between the Quality of Voluntary and Compulsory Disclosure and Information Asymmetry. International Journal of Academic Research in Business and Social Sciences, v. 6, n. 1, p. 154-163, 2016.

GOUNDAR, Nadesa. Impression management in financial reports surrounding CEO turnover. Unpublished Master's Thesis, Unitec New Zealand, New Zealand, 2009.

GUIDE, Eviews User's. Quantitative Micro Software. United States of America, 2007.

GUILLAMON-SAORIN, Encarna; GARCIA OSMA, B.; AERTS, W. Self-serving financial reporting communication: A study of the association between earnings management and impression management. Cahier de recherche, Universidad Carlos III Madrid, 2010.

GUJARATI, D. N. Basic econometrics. Tata McGraw-Hill Education, 2006.

GREENE, William H. Econometricanalysis. Pearson EducationIndia, 2012.

HASAN, Md. Tanvir; HOUSAIN, Md. Zakir. Corporate Mandatory and Voluntary Disclosure Practices in Bangladesh: Evidence from listed companies of Dhaka Stock Exchange. Research Journal of Finance and Accounting, Vol.6, No.12, 2015

HAWASHE, Abdallah Al-mahdy. Commercial Banks' Attributes and Annual Voluntary Disclosure: The case of Libya. International Journal of Accounting and Financial Reporting, v. 5, n. 2, p. 208-233, 2016.

HEALY, Paul M; PALEPU, Krishina, G.Information Asymmetry, Corporate Disclosure, and the Capital Markets: A Review of the Empirical Disclosure Literature, Journal of Accounting and Economics 31, 405-441, 2001.

HEALY, Paul M.; WAHLEN, James M. A review of the earnings management literature and its implications for standard setting. Accounting horizons, v. 13, n. 4, p. 365-383, 1999.

HENDRIKSEN, Eldon S., BREDA, Michael F. Van. Teoria da Contabilidade. Tradução Antônio ZorattoSanvicente. São Paulo: Atlas, 1999.

HUANG, S.Y., CHUNG Y.H., CHENG W.W. The effects between numerical tabulations and graphs of financial information on the judgment of investors. Review of Business Information Systems, 12 (4):41-56, 2008.

HUFF, D. How to Lie with Statistics. New York: W. Norton, 1954.

INCHAUSTI, BegoñaGiner. The influence of company characteristics and accounting regulation on information disclosed by Spanish firms. European accounting review, v. 6, n. 1, p. 45-68, 1997. 
JOHNSON, J.R., RICE, R.R. and ROEMMICH, R.A. Pictures that lie: the abuse of graphs in annual reports. Management Accounting. October, 50-56, 1980.

JONES, Michael John; SLACK, Richard Slack. Environmental Disclosure And Targets In Environmental Reports: Impression Management Or Legitimacy Theory, FondazioneCesifin Alberto Predieri, 2011.

KORN, Evelyn; SCHILLER, Ulf, Voluntary Disclosure of Nonproprietary Information: A Complete Equilibrium Characterization, in: Journal of Business Finance and Accounting, Vol. 30, pp. 1327-1339, 2002.

KOSSLYN, Stephen M. Understanding charts and graphs. Applied cognitive psychology, v. 3, n. 3, p. $185-225,1989$.

KRAEMER, Maria Elisabeth Pereira. Contabilidade criativa: maquiando as demonstrações contábeis.PensarContábil, v. 7, n. 28, 2008.

LEARY, M. R., KOWALSKI, R. M..'Impression management: a literature review and twocomponent model'.Psychological Bulletin, 107(1): 34-47, 1990.

LI, Feng. Annual report readability, current earnings, and earnings persistence. Journalof Accountingandeconomics, v. 45, n. 2, p. 221-247, 2008.

LIMA, Gerlando Augusto Sampaio Franco de et al. Influência do "disclosure" voluntário no custo de capital de terceiros. In: CONGRESSO USP DE CONTROLADORIA E

CONTABILIDADE, 7., 2007, São Paulo. Anais ... São Paulo: FEA/USP, 2007. 1 CD-ROM.

MACAGNAN, Clea Beatriz. Evidenciação voluntária: fatores explicativos da extensão da informação sobre recursos intangíveis. Revista Contabilidade \& Finanças, v. 20, n. 50, p. 46$61,2009$.

MADDALA, Gangadharrao S.; WU, Shaowen. A comparativestudyofunit root testswithpanel data and a new simple test. Oxford BulletinofEconomicsandstatistics, v. 61, n. S1, p. 631-652, 1999.

MARTINS, Gilberto de Andrade. THEÓPHILO, Carlos Renato. Metodologia da investigação científica para ciências sociais aplicadas.2. ed. São Paulo, Atlas, 2009. 247 p.

MATHER, P., RAMSAY, A; SERRY, A, "The Use and Representational Faithfulness of Graphsin Annual Reports: Australian Evidence", Australian Accounting Review, Vol.6, No.2, 1996.

MATHER, P., A. Ramsay and A. Steen. 2000. The use and representational faithfulness of graphs in Australian IPO prospectuses. Accounting, Auditing and Accountability Journal. 13 (1): 65-83.

MEEK, G.K., ROBERTS, C.B., \& Gray, S.J. Factors influencing voluntary annual report disclosures by U.S.,U.K. and Continental European multinational corporations, Journal of International Business Studies, 26(3), pp. 555-572, 1995. 
MELO, Francisco Matheus Alves; PONTE, Vera Maria Rodrigues; OLIVEIRA, Marcelle Colares. Análise das práticas de evidenciação de informações avançadas e nãoobrigatórias nas demonstrações contábeis das empresas brasileiras. Revista deContabilidade e Organizações, FEARP/USP, v. 1, n. 1, p. 30-42, set/dez 2007.

MENDONÇA, José Ricardo Costa de ; VIEIRA, M. M. F. ; SANTO, T. M. V. E. . Gerenciamento de Impressões, Comunicações e Ações Simbólicas como Elementos Facilitadores na Gestão de Processos de Mudança Organizacional. In: Encontro da Associação Nacional dePós-Graduação em Administração, 1999, Foz do Iguaçú. Anais do 23º ENANPAD, 1999.

MENDONÇA, J. R. C. ; HELAL, D. H. . O Enquadramento na Relação Organização-Stakeholder: um modelo teórico explicativo do processo de legitimação com base nas teorias de gerenciamento de impressões organizacional e de framing. In: XXXV EnANPAD, 2011, Rio de Janeiro. Anais do XXXV Enanpad 2011. Rio de Janeiro: ANPAD, 2011.

MERKL-DAVIES, Doris M.; BRENNAN, Niamh M. Discretionary disclosure strategies in corporate narratives: incremental information or impression management?.Journalofaccountingliterature, v. 27, p. 116-196, 2007.

MIRANDA, L. C.; VIEIRA, A.S.; LAGIOIA, U.C.T.; VASCONCELLOS, M.T.C. Utilização de Gráficos em Demonstrações Contábeis. Revista de Educação e Pesquisa em Contabilidade. Vol. 2, n. 3, art. 2, p. 16-35, set/dez. 2008.

MILNE, Markus J.; ADLER, Ralph W. Exploring the reliability of social and environmental disclosures content analysis. Accounting, Auditing\&AccountabilityJournal, v. 12, n. 2, p. 237 256, 1999.

MOHAMED, A.A.; GARDNER, W.L; PAOLILLO, J.G.P. A taxonomy of organization impression management tatics .Advances in Competitiveness Research, v. 7, n. 1, p. 108 a 130, 1999.

MOHAMAD, ZamZuriyati et al. Does Quality of Non-Financial Information Disclosure Influence Firms' Profitability in Malaysia?. International Journal of Academic Research in Accounting, Finance and Management Sciences, v. 4, n. 4, p. 297-306, 2014.

MOREIRA, F. N.; MENEZES, BRUNNO NUINES DA COSTA ; MACEDO, M. A. S. ; ROSSI, M. Z. G. . Análise do Impacto de Variáveis Financeiras na Qualidade do Nível de Evidenciação: um estudo das demonstrações financeiras do setor brasileiro de energia elétrica no ano de 2009. In: IICongresso Nacional de Administração e Ciências Contábeis AdCont2011, 2011, Rio de Janeiro. II

MUIÑO, Flora; TROMBETTA, Marco. Does graph disclosure bias reduce the cost of equity capital?.Accounting and Business Research, v. 39, n. 2, p. 83-102, 2009.

MURCIA, Fernando Dal Ri. Fatores determinantes do Nível de Disclosure Voluntário das empresas brasileiras de capital aberto. São Paulo. Tese (Doutorado em Administração)Faculdade de Economia, Administração e Contabilidade da Universidade de São Paulo, 2009. 
MURCIA, Fernando Dal-ri; SANTOS, Ariovaldo dos. Fatores determinantes do nível de disclosure voluntário das companhias abertas no Brasil. Revista de Educação e Pesquisa em Contabilidade, v. 3, n. 2, p. 72-95, maio/ago. 2009.

NASCIMENTO, Marina Dutra ; RODRIGUES, F. F. ; ALBUQUERQUE, Pedro Henrique Melo; Silva, César Augusto Tibúrcio . Gerenciamento Da Apresentação: Uma Análise Da Utilização De Gráficos Nos Relatórios Da Administração.RevistaUniversoContábil, v. 9, p. 4664, 2013.

OSMA, Beatriz García; GUILLAMON-SAORIN, Encarna;.; AERTS, W. Self-serving financial reporting communication: A study of the association between earnings management and impression management. Cahier de recherche, UniversidadCarlos III Madrid, 2010.

OSMA, Beatriz García; GUILLAMÓN-SAORÍN, Encarna. Corporate governance and impression management in annual results press releases.Accounting, OrganizationsandSociety, v. 36, n. 4, p. 187-208, 2011.

OWUSU-Ansah, S. \&Yeoh, J. "The effect of legislation on corporate disclosure practices", Abacus 41(1), 92-109, 2005.

PENROSE, J. M.. "Annual Report Graphic Use: A Review of the Literature". Journalof Business Communication 45 (2): 158-180, 2008.

PEREIRA, C. C.; FRAGOSO, A. R.; RIBEIRO FILHO, J. F. Comunicação em contabilidade: um estudo comparativo do nível de percepção dos usuários da informação contábil em Florianópolis (SC) e Recife (PE) sobre a utilidade das representações gráficas no processo de evidenciação. In: Congresso USP de Controladoria e Contabilidade, 4., 2004. Anais... São Paulo: FEA/USP, 2004

PENTEADO, I.A.M; Gerenciamento de Impressão em Relatórios de Sustentabilidade: Análise do Uso de Gráficos. Dissertação (Mestrado em Ciências Contábeis), São Paulo, 2013. Universidade de São Paulo, Programa de Pós-Graduação em Controladoria e Contabilidade.

PRODANOV, Cleber Cristiano; DE FREITAS, Ernani Cesar. Metodologia do Trabalho Científico: Métodos e Técnicas da Pesquisa e do Trabalho Acadêmico- $2^{\text {a }}$ Edição. Editora Feevale, 2013.

RAHMAN, Azhar Abdul; HAMDAN, MohdDiah; IBRAHIM, MohdAzhar. The use of graphs in Malaysian companies' corporate reports: A longitudinal study. Procedia-Social andBehavioralSciences, v. 164, p. 653-666, 2014.

ROBERTS, Robin W. Determinants of corporate social responsibility disclosure: An application of stakeholder theory. Accounting, OrganizationsandSociety, v. 17, n. 6, p. 595-612, 1992.

RODRIGUES, Fernanda Fernandes ; SILVA, César Augusto Tibúrcio . Análise das Variáveis que Influenciam as Informações Divulgadas nos Relatórios da Administração das Companhias Abertas Brasileiras: um estudo empírico nos anos de 2001 A 2003. In: $6^{\circ}$ Congresso Usp de Controladoria e Contabilidade, 2006, São Paulo. $6^{\circ}$ Congresso Usp de Controladoria e Contabilidade, 2006. 
RODRIGUES, Fernanda Fernandes. Fatores Determinantes Das Características Das Informações Divulgadas No Relatório Da Administração Das Empresas Brasileiras De Capital Aberto. Tese (Doutorado em Ciências Contábeis) Brasília, 2012. Universidade de Brasília, Programa Multiinstitucional e Inter- Regional de Pós- Graduação.

ROWBOTTOM, M., LYMER, A., Exploring use and users of narrative reporting in the online annual report, Journal of Applied Accounting Research, Vol. 11, No. 2, pp. 90-108,2010.

SALOTTI, Bruno Meirelles; YAMAMOTO, Marina Mitiyo. Ensaio sobre a Teoria da Divulgação. Brazilian Business Review, v. 2, n. 1, p. 53-70, 2005.

SOLIMAN, Mohammed. Firm characteristics and the extent of voluntary disclosure: the case of Egypt. Research Journal of Finance and Accounting, v. 4, n. 17, 2013.

GAMBOA, Sanches; Epistemologia da Pesquisa na Educação, Campinas, UNICAMP, Tese de Doutorado em Educação, 1987.

GONÇALVES, Rodrigo de Souza. Social Disclosure E Custo De Capital Próprio Em Empresas Brasileiras De Capital Aberto. Tese (Doutorado em Ciências Contábeis) Brasília, 2011. Universidade de Brasília, Programa Multiinstitucional e Inter0Regional de PósGraduação.Ano de obtenção: 2011.

SARTAWI, Iaad IS Mustafa. Graphical Reporting Practices In The Annual Reports Of Jordanian Banks: An Empirical Analysis. Corporate Ownership\&Control, p. 371,2015.

SILVA, César Augusto Tibúrcio; LIMA, Diogo Henrique Silva. FormulationEffect: Influência da Forma de Apresentação sobre o Processo Decisório de Usuários de Informações Financeiras. In: Encontro Da Associação Nacional De Pós-Graduação E Pesquisa Em Administração, 31., 2007, Rio de Janeiro. Anais... Rio de Janeiro 2007.

SILVA, C. A. T. ; RODRIGUES, Fernanda Fernandes ; Maria Lizete da Silveira ; SILVEIRA, Karen Josete da . Relatórios da Administração das Companhias Brasileiras de CapitalAberto:uma Análise Qualitativa. Contextus. Revista Contemporânea de Economia e Gestão, v. 4, p. 7-16, 2006.

SILVA, César Augusto Tibúrcio; RODRIGUES, Fernanda Fernandes; ABREU, Robson Lopes. Análise dos relatórios de administração das companhias abertas brasileiras: um estudo do exercício social de 2002.Revista de Administração Contemporânea, v. 11, n. 2, p. 71-92, 2007.

SOUSA, André Carlos; Gerenciamento De Impressão No Brasil: Uma Análise Das Mensagens Dos Presidentes Publicadas Nos Relatórios Anuais. Dissertação (Mestrado em Ciências Contábeis). Florianópolis, Universidade Federal de Santa Catarina, Programa de Pós Graduação em Contabilidade, 2013.

SOUTO-MAIOR, Cesar Duarte; FERREIRA, A. F. ; SOUZA, A. C. ; BORBA, José Alonso . Gerenciamento de Impressão de Gráficos: Uma Análise Experimental de Investimentos com Estudantes de Graduação. In: XXXVI ENANPAD - Encontro Nacional da ANPAD, 2012, Rio de Janeiro. XXXVI ENANPAD - Encontro Nacional da ANPAD, 2012. 
SOUZA, Wellington Dantas de; NASCIMENTO, João Carlos Hipólito Bernardes; BERNARDES, Juliana Reis. CONTABILIDADE CRIATIVA VERSUS CIÊNCIA CONTÁBIL: um estudo dos impactos do fenômeno sobre a ciência. RevistaOpara, v. 3, n. 1, 2013.

STANTON, P.; STANTON, John. Researching Corporate Annual Reports: An Analysis Of Perspectives Used. 2001.

STANTON, P.;J. STANTON, \&G.Pires, "Impressions of an annual report: an experimental study” Corporate Communications: An International Journal, 9(1), 2004.

STEINBART, P.J. The auditor's responsibility for the accuracy of graphs in annual reports: some evidence of the need for additional guidance. Accounting Horizons. 3 (3): 60-70, 1989.

TAYLOR, Barbara G.; ANDERSON, Lane K. Misleading Graphs-Guidelines For The Accountant. Journal of Accountancy, v. 162, n. 4, p. 126-\&, 1986.

TUFTE, Edward R.; The visual display of quantitative information. Cheshire, CT: Graphics press, 1983.

UYAR, A.. Firm characteristics and voluntary disclosure of graphs in annual reports of Turkish listed companies. African Journal of Business Management, 5(17), 7651-7657,2011.

UYAR, Ali; KILIC, Merve; BAYYURT, Nizamettin. Association between firm characteristics and corporate voluntary disclosure: Evidence from Turkish listed companies. Intangible Capital, v. 9, n. 4, p. 1080-1112, 2013.

VERRECCHIA, R.E., 1990. Discretionary disclosure and information quality. Journal of Accounting and Economics 12, 179-194.

2001.

Essays on Disclosure. Journal of Accounting and Economics, v. 32, p. 97-180,

WATTS, R., \&ZIMMERMAN, J. , "Positive accounting theory: a ten year perspective", The Accounting Review 65, 131-157, 1990.

WILLS, D. Perceptions of Company Performance: A Study of Impression Management Working paper, University of Tasmania, 2008.

WILLIAMS, P. Richard; MARTIN, Tennessee. Deception In Financial Graph Presentation: A Behavioral Test Of Influences.International Journal of the Academic Business World, v. 9, n. 1,2015

WOOLDRIDGE JEFFREY, M. Introductoryeconometrics. A modern approach. Mason, OH: Thomson South-Western, 2003. 


\section{APÊNDICE A - Amostra de Empresas para Análise}

\begin{tabular}{|c|c|c|}
\hline 1 & AES SUL DISTRIBUIDORA GAÚCHA DE ENERGIA S/A & Energia Elétrica \\
\hline 2 & ALEF AS & Emp. Adm. Part. - Sem Setor Principal \\
\hline 3 & ALFA HOLDING S/A & Emp. Adm. Part. - Sem Setor Principal \\
\hline 4 & ALL AMERICA LATINA LOGISTICA MALHA NORTE S/A & Serviços Transporte e Logística \\
\hline 5 & ALL AMERICA LATINA LOGISTICA MALHA SUL S/A & Serviços Transporte e Logística \\
\hline 6 & AMPLA ENERGIA E SERVIÇOS S/A & Energia Elétrica \\
\hline 7 & BAHEMA S/A & Participação em outras sociedades \\
\hline 8 & BANCO BRADESCO S/A & Bancos \\
\hline 9 & BANCO DA AMAZÔNIA & Intermediação Financeira \\
\hline 10 & BANCO DO BRASIL S/A & Bancos \\
\hline 11 & BANCO DO ESTADO DE SERGIPE S/A & Bancos \\
\hline 12 & BANCO DO ESTADO DO PARÁ & Bancos \\
\hline 13 & BANCO MERCANTIL BRASIL S/A & Bancos \\
\hline 14 & $\begin{array}{l}\text { BANESTES S.A BANCO DO ESTADO DO ESPÍRITO } \\
\text { SANTO }\end{array}$ & Bancos \\
\hline 15 & BANRISUL ARMAZÉNS GERAIS S/A & Serviços Transporte e Logística \\
\hline 16 & BARDELLA S.A INDS. MECANICAS & Máquinas, Equipamentos, Veículos e Peças \\
\hline 17 & BATTISTELLA ADM E PARTICIPAÇÕES S/A & Emp. Adm. Part. - Sem Setor Principal \\
\hline 18 & BAUMER S.A & Metalurgia e Siderurgia \\
\hline 19 & BCO ALFA DE INVESTIMENTOS S/A & Bancos \\
\hline 20 & BELAPART S/A & Participação em outras sociedades \\
\hline 21 & BICICLETAS MONARK S/A & Brinquedos e Lazer \\
\hline 22 & BMG LEASING S/A - ARRENDAM. MERCANTIL & Arrendamento Mercantil \\
\hline 23 & BOMBRIL S/A & Farmacêutico e Higiene \\
\hline 24 & BRASKEM S/A & Petroquímicos e Borracha \\
\hline 25 & BRASMOTORS S/A & Máquinas, Equipamentos, Veículos e Peças \\
\hline 26 & BRB BANCO DE BRASÍLIA S/A & Bancos \\
\hline 27 & BRF S/A & Emp. Adm. Part. - Alimentos \\
\hline 28 & BUETNNER S/A INDUSTRIA E COMERCIO & Têxtil e Vestuário \\
\hline 29 & CAIXA ADM DIV PUB ESTADUAL S/A & Intermediação Financeira \\
\hline 30 & CAMBUCI S/A & Têxtil e Vestuário \\
\hline 31 & CARBOMIL SA MINER. E INDUSTRIA & Extração Mineral \\
\hline 32 & CIA ENERGETICA DE BRASILIA - CEB & Energia Elétrica \\
\hline 33 & CELULOSE IRANI S/A & Papel e Celulose \\
\hline 34 & CEMEPE INVESTIMENTOS AS & Emp. Adm. Part. - Sem Setor Principal \\
\hline 35 & CENTRAIS ELETRICAS BRASILEIRAS AS & Energia Elétrica \\
\hline 36 & CENTRAIS ELETRICAS DE SANTA CATARINA S.A & Energia Elétrica \\
\hline 37 & CENTRAIS ELETRICAS MATOGROSSENSES S/A & Energia Elétrica \\
\hline 38 & CIA ELETRICIDADE SÃO FRANCISCO & Energia Elétrica \\
\hline 39 & CIA ELETROAÇO & Metalurgia e Siderurgia \\
\hline 40 & CIA ENERG CEARA - COELCE & Energia Elétrica \\
\hline 41 & CIA ENERGÉTICA DA BAHIA - COELBA & Energia Elétrica \\
\hline 42 & CIA ENERGÉTICA DE PERNAMBUCO - CELPE & Energia Elétrica \\
\hline 43 & CIA ESTADUAL GER.TRANS.ENER.ELET-CEEE-GT & Energia Elétrica \\
\hline 44 & CIA FERRO LIGAS DA BAHIA - FERBASA & Metalurgia e Siderurgia \\
\hline 45 & CIA HABITASUL DE PARTICIPACOES & Emp. Adm. Part. Sem. Setor Principal \\
\hline 46 & CIA HERING & Têxtil e Vestuário \\
\hline 47 & CIA INDUSTRIAL CATAGUASES & Têxtil e Vestuário \\
\hline 48 & CIA PAULISTA DE FORCA E LUZ & Energia Elétrica \\
\hline 49 & CIA SANEAMENTO BÁSICO ESTADO SÃO PAULO & Saneamento, Serv. Água e Gás \\
\hline
\end{tabular}




\begin{tabular}{|c|c|c|}
\hline 50 & CIA SEGUROS ALIANCA BAHIA & Seguradoras e Corretoras \\
\hline 51 & CIA SIDERURGICA NACIONAL & Metalurgia e Siderurgia \\
\hline 52 & CIA TECIDOS SANTANENSE & Têxtil e Vestuário \\
\hline 53 & CIA. DISTRIB. DE GÁS DO RIO DE JANEIRO & Saneamento, Serv. Água e Gás \\
\hline 54 & CIMS S/A & Emp. Adm. Part. - Sem Setor Principal \\
\hline 55 & COBRASMA S/A & Máquinas, Equipamentos, Veículos e Peças \\
\hline 56 & COMERCIAL QUINTELLA COM EXP AS & Serviços Transporte e Logística \\
\hline 57 & COMPANHIA BRASILEIRA DE DISTRIBUIÇÃO & Comércio (Atacado e Varejo) \\
\hline 58 & COMPANHIA DE ÁGUAS E ESGOTO - CEDAE & Saneamento, Serv. Água e Gás \\
\hline 59 & COMPANHIA DE GÁS DE SÃO PAULO - COMGÁS & Emp. Adm. Part. - Saneamento, Serv. Água e Gás \\
\hline 60 & COMPANHIA ENERGÉTICA DE SÃO PAULO - CESP & Energia Elétrica \\
\hline 61 & COMPANHIA MELHORAMENTOS DE SÃO PAULO & Emp. Adm. Part. - Papel e Celulo \\
\hline 62 & CONPEL CIA NORDESTINA PAPEL & Energia Elétrica \\
\hline 63 & CONSERVAS ODERICH S.A. & Emp. Adm. Part. - Intermediação Financeira \\
\hline 64 & CONSORCIO ALFA DE ADMINISTRACAO S.A. & Construção Civil, Mat. Constr. e Decoração \\
\hline 65 & CONST ADOLPHO LINDENBERG AS & Construção Civil, Mat. Constr. e Decoração \\
\hline 66 & CONSTRUTORA LIX DA CUNHA S.A. & Construção Civil, Mat. Constr. e Decoração \\
\hline 67 & CORREA RIBEIRO S.A. COMERCIO E INDUSTRIA & Construção Civil, Mat. Constr. e Decoração \\
\hline 68 & CIA TECIDOS NORTE DE MINAS COTEMINAS & Têxtil e Vestuário \\
\hline 69 & CYRELA BRAZIL REALTY SA EMPRS E PARTS & Construção Civil, Mat. Constr. e Decoração \\
\hline 70 & DIBENS LEASING S.A.- ARREND. MERCANTIL & Arrendamento Mercantil \\
\hline 71 & DIGITEL SA INDUSTRIA ELETRONICA & Comunicação e Informática \\
\hline 72 & DIMED S.A. DISTRIBUIDORA DE MEDICAMENTOS & Comércio (Atacado e Varejo) \\
\hline 73 & DOHLER S.A. & Têxtil e Vestuário \\
\hline 74 & ELETROBRÁS PARTICIPAÇÕES S.A. - ELETROPAR & Emp. Adm. Part. - Energia Elétrica \\
\hline 75 & ELETRON S.A & Emp. Adm. Part. - Sem Setor Principal \\
\hline 76 & ELETROPAULO METROPOLITANA EL.S.PAULO S.A & Emp. Adm. Part. - Máqs., Equip., Veíc. e Peças \\
\hline 77 & EMP.NAC.C., RÉDITO E PART. S.A. ENCORPAR & Emp. Adm. Part. - Têxtil e Vestuário \\
\hline 78 & ENERGIPAR PARTICIPAÇÕES S.A. & $\begin{array}{l}\text { Emp. Adm. Part. - Const. Civil, Mat. Const. e } \\
\text { Decoração }\end{array}$ \\
\hline 79 & $\begin{array}{l}\text { ENERGISA MATO GROSSO DO SUL - DISTRIBUIDORA } \\
\text { DE ENERGIA S/A }\end{array}$ & Energia Elétrica \\
\hline 80 & ENERGISA MATO GROSSO DO SUL S/A & Energia Elétrica \\
\hline 81 & $\begin{array}{l}\text { ENERGISA MINAS GERAIS - DISTRIBUIDORA DE } \\
\text { ENERGIA S/A }\end{array}$ & Energia Elétrica \\
\hline 82 & ESPIRITO SANTO CENTRAIS ELETRICAS AS & Energia Elétrica \\
\hline 83 & ETERNIT S.A. & Construção Civil, Mat. Constr. e Decoração \\
\hline 84 & EUCATEX SA IND E COMERCIO & Construção Civil, Mat. Constr. e Decoração \\
\hline 85 & ÉVORA S.A. & Emp. Adm. Part. - Embalagens \\
\hline 86 & FERROVIA CENTRO ATLANTICA S/A & Serviços Transporte e Logística \\
\hline 87 & FIBAM CIA INDUSTRIAL & Metalurgia e Siderurgia \\
\hline 88 & FIBRIA CELULOSE S.A. & Papel e Celulose \\
\hline 89 & FINANCEIRA ALFA S.A.- C.F.I & Intermediação Financeira \\
\hline 90 & FINANSINOS S/A-CRÉDITO, FINAN. E INVEST. & Bancos \\
\hline 91 & FORJAS TAURUS S.A. & Metalurgia e Siderurgia \\
\hline 92 & FRAS-LE S/A & Máquinas, Equipamentos, Veículos e Peças \\
\hline 93 & GAFISA S/A & Construção Civil, Mat. Constr. e Decoração \\
\hline 94 & GPC PARTICIPACOES S/A & Emp. Adm. Part. - Petroquímicos e Borracha \\
\hline 95 & GRUÇAI PARTICIPAÇÕES AS & Emp. Adm. Part. - Serviços Transporte e Logística \\
\hline 96 & GUARARAPES CONFECCOES S.A & Têxtil e Vestuário \\
\hline 97 & HAGA S.A. INDÚSTRIA E COMÉRCIO & Metalurgia e Siderurgia \\
\hline 98 & HAUSCENTER AS & Emp. Adm. Part. - Sem Setor Principal \\
\hline 99 & HERCULES S/A - FABRICA DE TALHERES & Metalurgia e Siderurgia \\
\hline
\end{tabular}




\begin{tabular}{|c|c|c|}
\hline 100 & IND AZULEJOS BAHIA AS & Construção Civil, Mat. Constr. e Decoração \\
\hline 101 & INDS J B DUARTE AS & Alimentos \\
\hline 102 & INEPAR TELECOMUNICACOES S.A. & Telecomunicações \\
\hline 103 & INVESTIMENTOS BEMGE S.A. & Emp. Adm. Part. - Sem Setor Principal \\
\hline 104 & ITAÚ SA - INVESTIMENTOS ITAÚ S.A. & Emp. Adm. Part. - Sem Setor Principal \\
\hline 105 & JEREISSATI PARTICIPAÇÕES S.A & Emp. Adm. Part. - Telecomunicações \\
\hline 106 & JOSAPAR-JOAQUIM OLIVEIRA S.A. - PARTICIP & Alimentos \\
\hline 107 & KARSTEN S.A & Têxtil e Vestuário \\
\hline 108 & KEPLER WEBER S.A & Emp. Adm. Part. - Metalurgia e Siderurgia \\
\hline 109 & LA FONTE TELECOM S/A & Emp. Adm. Part. - Telecomunicações \\
\hline 110 & LIGHT SERVICOS DE ELETRICIDADE S.A. & Energia Elétrica \\
\hline 111 & LITEL PARTICIPACOES S.A & Emp. Adm. Part. - Extração Mineral \\
\hline 112 & LOJAS RENNER S/A & Comércio (Atacado e Varejo) \\
\hline 113 & MANUFATURA DE BRINQUEDOS ESTRELAS & Brinquedos e Lazer \\
\hline 114 & MARCOPOLO S.A & Máquinas, Equipamentos, Veículos e Peças \\
\hline 115 & MARINA DE IRACEMA PARK S/A & Hospedagem e Turismo \\
\hline 116 & MENDES JUNIOR ENGENHARIA S.A & Construção Civil, Mat. Constr. e Decoração \\
\hline 117 & MERCANTIL DO BR FINC SA CFI & Bancos \\
\hline 118 & MERCANTIL DO BRASIL LEASING S/A & Arrendamento Mercantil \\
\hline 119 & METALGRÁFICA IGUAÇU S.A & Metalurgia e Siderurgia \\
\hline 120 & METALURGICA RIOSULENSE S.A & Metalurgia e Siderurgia \\
\hline 121 & METANOR SA METANOL DO NE & Petroquímicos e Borracha \\
\hline 122 & METISA METALÚRGICA TIMBOENSE S.A & Metalurgia e Siderurgia \\
\hline 123 & MINASMAQUINAS S.A & Máquinas, Equipamentos, Veículos e Peças \\
\hline 124 & MINUPAR PARTICIPACOES S.A. & Emp. Adm. Part. - Alimentos \\
\hline 125 & MONTEIRO ARANHA S.A. & Emp. Adm. Part. - Sem Setor Principal \\
\hline 126 & MUNDIAL S.A - PRODUTOS DE CONSUMO & Têxtil e Vestuário \\
\hline 127 & NADIR FIGUEIREDO IND E COM AS & Extração Mineral \\
\hline 128 & NEOENERGIA S.A & Emp. Adm. Part. - Energia Elétrica \\
\hline 129 & NEUMARKT TRADE AND FINANCIAL CENTER S/A & Crédito Imobiliário \\
\hline 130 & NORDON INDUSTRIAS METALURGICAS S.A. & Metalurgia e Siderurgia \\
\hline 131 & OI S.A. & Telecomunicações \\
\hline 132 & PANATLANTICA S.A & Metalurgia e Siderurgia \\
\hline 133 & PARANAPANEMA S.A. & Metalurgia e Siderurgia \\
\hline 134 & PARTICIPAÇÕES INDUST. DO NORDESTE S.A. & Emp. Adm. Part. - Sem Setor Principal \\
\hline 135 & PETROLEO LUB DO NORDESTE AS & Petróleo e Gás \\
\hline 136 & PLASCAR PARTICIPAÇÕES INDUSTRIAIS S.A & Emp. Adm. Part. - Máqs., Equip., Veíc. e Peças \\
\hline 137 & POLPAR S.A. & Emp. Adm. Part. - Sem Setor Principal \\
\hline 138 & PORTO SEGURO SA & Emp. Adm. Part. - Sem Setor Principal \\
\hline 139 & PORTOBELLO S/A & Construção Civil, Mat. Constr. e Decoração \\
\hline 140 & PORTUENSE FERRAGENS S.A & Construção Civil, Mat. Constr. e Decoração \\
\hline 141 & RAIA DROGASIL S.A. & Comércio (Atacado e Varejo) \\
\hline 142 & RANDON S.A. IMPLEMENTOS E PARTICIPAÇÕES & Máquinas, Equipamentos, Veículos e Peças \\
\hline 143 & RECRUSUL S.A & Máquinas, Equipamentos, Veículos e Peças \\
\hline 144 & REDE ENERGIA S.A & Energia Elétrica \\
\hline 145 & ROSSI RESIDENCIAL S.A & Construção Civil, Mat. Constr. e Decoração \\
\hline 146 & SANSUY SA INDÚSTRIA DE PLASTICOS S.A & Petroquímicos e Borracha \\
\hline 147 & SANTA CATARINA PART INVEST S.A & Petroquímicos e Borracha \\
\hline 148 & SANTHER FAB.DE PAPEL SANTA THEREZINHA S.A & Papel e Celulose \\
\hline 149 & SÃO PAULO ALPAGARTAS S/A & Têxtil e Vestuário \\
\hline 150 & SAO PAULO TURISMO S.A. & Emp. Adm. Part. - Hospedagem e Turismo \\
\hline 151 & SARAIVA SA LIVREIROS EDITORES & Gráficas e Editoras \\
\hline
\end{tabular}




\begin{tabular}{|l|l|l|}
152 & SCHULZ S.A. & Metalurgia e Siderurgia \\
\hline 153 & SHOPPING CENTER TACARUNA & Emp. Adm. Part. - Sem Setor Principal \\
\hline 154 & SIDERURGICA J. L. ALIPERTI S.A & Metalurgia e Siderurgia \\
\hline 155 & SNB PARTICIPACOES AS & Emp. Adm. Part. - Comércio (Atacado e Varejo) \\
\hline 156 & SOC.DE ABASTEC.DE ÁGUA E SANEAMENTO S.A. & Saneamento, Serv. Água e Gás \\
\hline 157 & SONDOTECNICA ENGENHARIA SOLOS S.A & Saneamento, Serv. Água e Gás \\
\hline 158 & SPRINGER S.A & Máquinas, Equipamentos, Veículos e Peças \\
\hline 159 & SUDESTE S.A. & Emp. Adm. Part. - Sem Setor Principal \\
\hline 160 & SUL 116 PARTICIPAÇÕES S.A & Emp. Adm. Part. - Telecomunicações \\
\hline 161 & SUZANO HOLDING S.A. & Emp. Adm. Part. - Papel e Celulose \\
\hline 162 & SUZANO PAPEL E CELULOSE S.A. & Papel e Celulose \\
\hline 163 & TEC TOY S.A & Máquinas, Equipamentos, Veículos e Peças \\
\hline 164 & TECNOSOLO S/A & Construção Civil, Mat. Constr. e Decoração \\
\hline 165 & TEKA TECELAGEM KUEHNRICH S/A & Têxtil e Vestuário \\
\hline 166 & TEKNO S.A - INDÚSTRIA E COMERCIO & Emp. Adm. Part. - Metalurgia e Siderurgia \\
\hline 167 & TERMINAIS PORT. DA PONTA DO FÉLIX S/A & Serviços Transporte e Logística \\
\hline 168 & TREVISA INVESTIMENTOS S.A & Emp. Adm. Part. - Sem Setor Principal \\
\hline 169 & TUPY S.A. & Metalurgia e Siderurgia \\
\hline 170 & UNIPAR CARBOCLORO S.A & Petroquímicos e Borracha \\
\hline 171 & USINAS SIDERUGICAS DE MINAS GERAIS S.A & Metalurgia e Siderurgia \\
\hline 172 & VALE S.A. & Extração Mineral \\
\hline 173 & VULCABRAS S.A & Têxtil e Vestuário \\
\hline 174 & WEG S/A & Emp. Adm. Part. - Máqs., Equip., Veíc. e Peças \\
\hline 175 & WEMBLEY SOCIEDADE ANONIMA & Emp. Adm. Part. - Têxtil e Vestuário \\
\hline 176 & WETZEL S.A & Metalurgia e Siderurgia \\
\hline 177 & WHIRLPOOL S.A. & Máquinas, Equipamentos, Veículos e Peças \\
\hline 178 & WTC AMAZONAS SUITE HOTEL S.A & Hospedagem e Turismo \\
\hline 179 & 521 PARTICIPAÇÕES S.A & Emp. Adm. Part. - Energia Elétrica \\
\hline 180 & 524 PARTICIPAÇÕES S.A & Emp. Adm. Part. - Sem Setor Principal \\
\hline
\end{tabular}

